Michele Silva de Barros

\title{
PADRONIZAÇÃO DE MODELO DE INFLAMAÇÃO ALÉRGICA PELA EXPOSIÇÃO A PICADAS DE MOSQUITOS
}

Aedes aegypti

Dissertação apresentada ao Programa de Pós-Graduação em Imunologia do Instituto de Ciências Biomédicas da Universidade de São Paulo, para a obtenção do Título de Mestre em Ciências. 


\section{PADRONIZAÇÃO DE MODELO DE INFLAMAÇÃO ALÉRGICA PELA EXPOSIÇÃO A PICADAS DE MOSQUITOS}

Aedes aegypti

Dissertação apresentada ao Programa de Pós-Graduação em Imunologia do Instituto de Ciências Biomédicas da Universidade de São Paulo, para a obtenção do Título de Mestre em Ciências.

Área de concentração: Imunologia

Orientador: Prof. Dr. Anderson de Sá Nunes

Versão corrigida. A versão original eletrônica encontra-se disponível tanto na Biblioteca do ICB quanto na Biblioteca Digital de Teses e Dissertações da USP (BDTD). 
DADOS DE CATALOGAC̣ÃO NA PUBLICAC̣ÃO (CIP)

Serviço de Biblioteca e Informaçăo Biomédica do

Instituto de Ciências Biomédicas da Universidade de Săo Paulo

reproduçāo nāo autorizada pelo autor

Barros, Michele Silva de.

Padronizaçãoo de modelo de inflamação alérgica pela exposição a picadas de mosquito Aedes aegypti / Michele Silva de Barros. -- São Paulo, 2012.

Orientador: Prof. Dr. Anderson Sá-Nunes.

Dissertação (Mestrado) - Universidade de São Paulo. Instituto de Ciências Biomédicas. Departamento de Imunologia. Área de concentraçăo: Imunologia. Linha de pesquisa: Imonumodulaçăo por componentes salivares de artrópodes hematófagos.

Versão do titulo para o ingles: Standardization of a model of allergic inflammation by exposure to Aedes aegypti mosquito bites.

1. Alergia 2. Aedes aegypti 3. Inflamação pulmonar

4. Eosinófilos 5. Citocinas I. Sá-Nunes, Prof. Dr. Anderson

II. Universidade de São Paulo. Instituto de Ciencias Biomedicas.

Programa de Pós-Graduaçăo em Imunologia III. Titulo. 


\begin{abstract}
Candidato(a):
Michele Silva de Barros.

Título da Dissertação:

Padronização de modelo de inflamação alérgica pela exposição a picadas de mosquito Aedes aegypti.
\end{abstract}

Orientador(a):

Prof. Dr. Anderson Sá-Nunes.
A Comissão Julgadora dos trabalhos de Defesa da Dissertação de Mestrado, em sessão pública realizada a ...................., considerou

\section{( ) Aprovado(a) \\ ( ) Reprovado(a)}
Examinador(a): Assinatura: Nome:
Instituição:
Examinador(a): Assinatura:
Nome:
Instituição:
Presidente: Assinatura:
Nome:
Instituição:




\section{Certificado}

Certificamos que o protocolo registrado sob $n^{\circ} \mathbf{1 4 8}$ nas fls. 111 do livro $\mathbf{0 2}$ para uso de animais em experimentação, sob a responsabilidade do Prof(a) $\operatorname{Dr}(a))$ Anderson de Sá Nunes, Coordenador (a) da Linha de pesquisa "Avaliação da hiperreatividade pulmonar e intestinal de animais expostos à picadas e extrato de glândula salivar do mosquito Aedes aegypti" do qual participam o(s) aluno(s) Michele Silva de Barros, Adriana Lino dos Santos Franco, Daniele Intini Gueroni, Thamy Caroline de Souza Silva e o pesquisador Wothan Tavares de Lima, está de acordo com os Princípios Éticos de Experimentação Animal adotado pela Sociedade Brasileira de Ciência de Animais de Laboratório (SBCAL) e foi aprovado pela COMISSÃO DE ÉTICA NO USO DE ANIMAIS (CEUA) em 04.10.2011, com validade de 4 anos.

São Paulo, 10 de outubro de 2011.
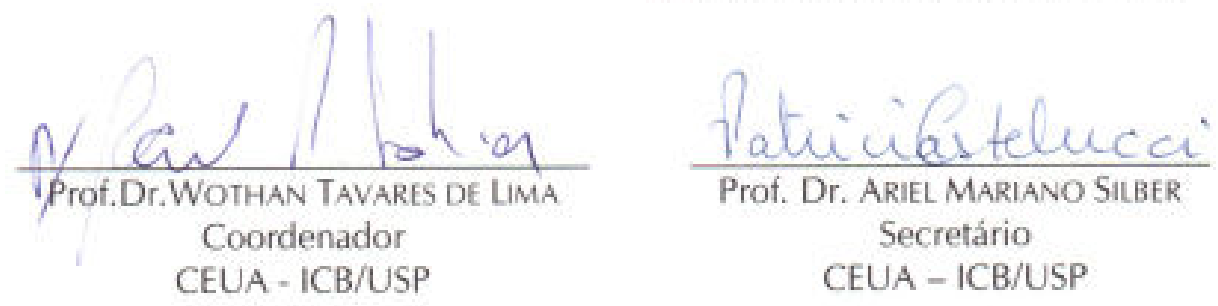


\section{Certificado}

Certificamos que o protocolo registrado sob $n^{\circ} \mathbf{1 4 0}$ nas fls. $\mathbf{1 1 1}$ do livro $\mathbf{0 2}$ para uso de animais em experimentação, sob a responsabilidade do Prof(a) Dr(a)) Anderson de Sá Nunes, Coordenador (a) da Linha de pesquisa "Avaliação do perfil imunológico de animais exposto à picadas e extrato de glândula salivar do mosquito Aedes aegypti" do qual participam o(s) aluno(s) Michele Silva de Barros, Bruna Bizzarro, Ciro Novaes Rosa Lino, Ceres Maciel de Miranda, Natany Bissiato, Thamy Caroline de Souza Silva, Esther Florsheim, Ana Paula Ligeiro de Oliveira, Luciana Mirotti, Lucas da Silva Faustino e o pesquisador Momtchilo Russo, está de acordo com os Princípios Éticos de Experimentaçåo Animal adotado pela Sociedade Brasileira de Ciêncía de Animais de Laboratório (SBCAL) e foi aprovado pela COMISSÃO DE ÉTICA NO USO DE ANIMAIS (CEUA) em 20.10.2011, com validade de 3 anos.

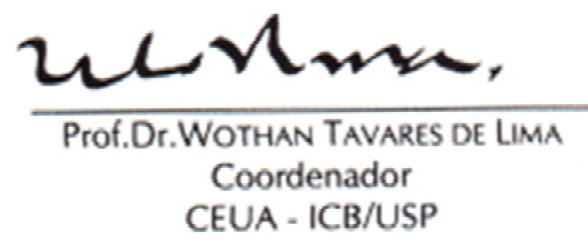

Săo Paulo, 25 de outubrode-2011.

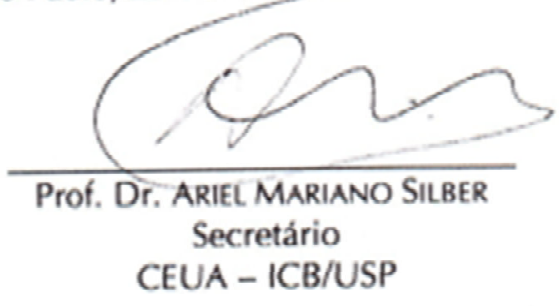


Dedico este trabalho aos meus pais, Jurandir e Ivonete, por todo amor, dedicação e carinho em todos os momentos da minha vida. 


\section{AGRADECIMENTOS}

Ao meu orientador, Prof. Anderson de Sá Nunes, por todos os ensinamentos durante o mestrado, pela oportunidade de fazer parte da sua equipe, por toda dedicação, incentivo, confiança e paciência. Pela oportunidade de crescimento profissional e por todos os esforços para a realização deste projeto.

Aos meus pais, Jurandir e Ivonete, por todos os esforços que fizeram para a minha formação, além do amor e carinho que sempre dedicaram a mim. Não há palavras que expressem o meu profundo sentimento de gratidão. Aos meus irmãos, Denis, Júnior e especialmente a Beatriz, pelo apoio, carinho, incentivo e presença em todos os momentos.

À minha tia Eliane, que ajudou na minha educação e cuidou muito bem de mim quando eu era criança (e continua cuidando!).

Ao José Eduardo, companheiro e amigo, por todo amor e carinho, pelas conversas, risadas, discussões e principalmente pela paciência e disposição em me ouvir.

Às minhas primas, Fernanda e Elisângela, e à minha cunhada, Daniele, por estarem sempre ao meu lado e torcendo pelas minhas conquistas.

À Professora Dra. Margareth de Lara Capurro Guimarães do Departamento de Parasitologia do ICB/USP, pela valiosa colaboração e por ceder os mosquitos Aedes aegypti.

Ao Professor Dr. Momtchilo Russo, pela colaboração, incentivo e tempo investido em discussões para o desenvolvimento deste trabalho.

Ao Professor Dr. Wothan Tavares de Lima e Dra. Adriana Lino dos Santos Franco, pela colaboração e ajuda com os experimentos de reatividade da traqueia e pela disponibilidade e atenção sempre oferecidas.

À Professora Sonia Jancar Negro, por compartilhar o espaço, materiais, reagentes e equipamentos de seus laboratórios.

Aos alunos do Laboratório de Imunologia Experimental, Bruna, Daniele, Ciro, Anderson Daniel, Thamy e Ceres, (muito mais que) companheiros de trabalho com os quais estou aprendendo a compartilhar conhecimentos e ideias e que me ensinam muito. Obrigada pela amizade, carinho, apoio, conversas, risadas, horas de bancada, pela ajuda em diversos experimentos e por tudo que aprendi com vocês. Obrigada por dividirem cada momento, cada problema e cada comemoração!

À Sandra, pelo seu apoio técnico indispensável para a realização deste trabalho. Agradeço pelo apoio inestimável durante todo este período.

À Eliane, pela amizade, dedicação e por tudo que, carinhosamente, me ensinou. À Luciana, por ter sido muito companheira, com quem sempre pude conversar e dividir minhas dúvidas. Ao 
Lucas, pela amizade e ajuda, principalmente com a análise das lâminas. À Esther e Ana Paula, pela amizade e carinho, pelas discussões sobre diversos protocolos e ajuda nos experimentos.

À Mari, Marlise, Silvana, Luciano, Matheus e Francisco, pela amizade, carinho e também porque tornaram essa caminhada muito mais divertida.

À Camila Stumm pela amizade, carinho e pela disposição em me ensinar a fazer a análise das lâminas. Obrigada por me dar a segurança de sempre poder contar com você.

À Camila Bonin, Fernanda, Tatiana, Mara e Lorena, pela amizade, pelas longas conversas e por terem dividido comigo também suas alegrias e experiências.

À Rafaella, amiga em diversos momentos, obrigada pelas conversas, pelo companheirismo, pela motivação, por toda força e apoio que tens me dado.

À querida amiga Jacqueline, que mesmo longe sempre esteve muito perto.

Ao Professor Fábio Henrique Kwasniewski, professor de Imunologia durante minha graduação, com quem tive o primeiro contato com a imunologia e também quem me indicou para o estágio no laboratório do Prof. Anderson.

Aos professores da minha banca de qualificação: Momtchilo Russo, Wothan Tavares de Lima e Renato Barboza, pela imensa contribuição com críticas e sugestões para a melhora deste trabalho.

Ao Bernardo Paulo Albe, pelo preparo do material histológico e confecção das lâminas.

Às técnicas Isabel, Ediane e Dona Neusa pelo cuidado na criação e manutenção dos mosquitos utilizados neste projeto.

À Dra. Denise Morais da Fonseca, pela ajuda de última hora para o fechamento de um resultado importante e ao Ciro, por ter me trazido os reagentes.

Ao Biotério de Camundongos Isogênicos do Departamento de Imunologia - ICB/USP pelo fornecimento e cuidado com os animais utilizados neste trabalho.

À Jotelma, Amanda e principalmente à Eni, pela ajuda com as questões burocráticas relacionadas a este trabalho.

Ao CNPq e a FAPESP pelo apoio financeiro concedido.

A todos que de alguma maneira contribuíram para este trabalho, Muito obrigada! 
Para ser grande, sê inteiro: nada

Teu exagera ou exclui. Sê todo em cada coisa. Põe quanto és

No mínimo que fazes. Assim em cada lago a lua toda Brilha, porque alta vive. 
O presente trabalho foi realizado com o apoio da Fundação de Amparo à Pesquisa do Estado de São Paulo (FAPESP) e Conselho Nacional de Pesquisa e Desenvolvimento (CNPq). 


\section{RESUMO}

BARROS, M. S. Padronização de modelo de inflamação alérgica pela exposição a picadas de mosquitos Aedes aegypti. 2012. 95 f. Dissertação (Mestrado em Imunologia) - Instituto de Ciências Biomédicas, Universidade de São Paulo, 2012.

Durante o repasto sanguíneo, fêmeas do mosquito Aedes aegypti inoculam saliva na pele de seu hospedeiro vertebrado, modulando suas funções imunológicas e facilitando a transmissão de doenças. Alguns componentes com ação anticoagulante, antiagregante de plaquetas e vasodilatadora já foram descritos na saliva de Ae. aegypti e agem neutralizando os efeitos da hemostasia, permitindo que a alimentação ocorra com sucesso. Além disso, trabalhos clássicos demonstraram que a secreção salivar é responsável pela sensibilização a picadas de mosquitos e que muitos dos componentes presentes na saliva são imunogênicos e capazes de provocar intensa resposta imune. A resposta imunológica a estes alérgenos compreende reações sistêmicas e locais severas com envolvimento de anticorpos IgE e subclasses de IgG e hipersensibilidade mediada por linfócitos T. Após uma picada de mosquito é possível observar uma resposta inflamatória e imune mensurável no local da picada e algumas dessas reações podem ser observadas através da coceira e inchaço que aparecem em seguida. Assim, o objetivo deste trabalho foi desenvolver um modelo para avaliar o perfil da resposta imunológica sistêmica desenvolvido por camundongos expostos naturalmente às picadas de mosquitos Ae. aegypti. Para isso, camundongos foram sensibilizados pela exposição ao Ae. aegypti e desafiados com PBS ou extrato da glândula salivar (EGS) do mosquito pela via intranasal. Paralelamente, este modelo foi comparado a um modelo clássico de inflamação alérgica pulmonar induzida pela sensibilização e posterior desafio com ovalbumina (OVA). Após os procedimentos de sensibilização e desafio, parâmetros de padrão respiratório e reatividade da traqueia e o infiltrado celular presente no lavado broncoalveolar (LBA) foi avaliado quantitativamente e qualitativamente nos animais. Além disso, citocinas presentes no LBA, perfil de anticorpos totais e específicos presentes no soro, secreção de muco e deposição de colágeno no tecido pulmonar foram determinados. Nossos resultados mostraram que camundongos sensibilizados pelas picadas dos mosquitos e desafiados com EGS apresentaram infiltrado celular no LBA dependente do número de exposições (" $1 \mathrm{x}$ " ou " $4 \mathrm{x}$ ") e composto majoritariamente de células mononucleares e eosinófilos. Dentre a população linfocitária, foi detectada a presença de células $\mathrm{CD}^{+}$e $\mathrm{CD} 19^{+}$. Esse perfil qualitativo de células presentes no LBA foi bastante semelhante ao grupo OVA. Em ambos os grupos, " $4 \mathrm{x}$ " e OVA, observamos aumento na população de células $\mathrm{T} \mathrm{CD}^{+}$produtoras de IL-4 e IL-5 no pulmão e presença destas citocinas no LBA. Além disso, foi observada uma intensa produção de muco pelas células do epitélio brônquico e pouca deposição de colágeno ao redor dos bronquíolos. Ambos os grupos apresentaram níveis aumentados de IgE total e IgG1 específico, porém, somente o grupo sensibilizado pelas picadas produziu quantidades significativas de IgG2a específicas. Ao contrário do grupo OVA, o grupo exposto aos mosquitos não apresentou alteração no padrão respiratório em resposta a metacolina. Além disso, também não foram observadas alterações na reatividade da traqueia em resposta à metacolina. Em conclusão, nossos resultados mostram que a resposta induzida pela sensibilização com a saliva do mosquito Ae. aegypti e desafio com EGS promove uma resposta mista, com produção de anticorpos tanto do perfil Th1 quanto Th2, migração de eosinófilos e células mononucleares para o espaço broncoalveolar, produção de muco no pulmão e ausência de alterações no padrão respiratório e reatividade da traqueia que são comuns em modelos de alergia pulmonar.

Palavras-chave: Alergia. Aedes aegypti. Inflamação pulmonar. Eosinófilos. Citocinas. 


\begin{abstract}
BARROS, M. S. Standardization of a model of allergic inflammation by exposure to Aedes aegypti mosquito bites. 2012. 95 f. Dissertation (Masters Thesis in Immunology) - Instituto de Ciências Biomédicas, Universidade de São Paulo, 2012.

During blood feeding, Aedes aegypti female mosquitoes inoculate saliva into the skin of their vertebrate hosts, modulating their immune functions and facilitating disease transmission. Some components with anticoagulant, antiplatelet and vasodilatory activities have been described in the saliva of Ae. aegypti that act by neutralizing the effects of hemostasis, allowing the meal to occur successfully. In addition, classical studies have shown that salivary secretion is responsible for the sensitization to mosquito bites and many of the components present in saliva are immunogenic and able to induce intense immune response. The immunological response to these allergens includes severe local and systemic reactions with involvement of IgE antibodies and IgG subclasses, and T cellmediated hypersensitivity. Following a mosquito bite, it is possible to observe a measurable immune and inflammatory response at the bite site and some of these reactions can be observed through the itching and swelling. Thus, the aim of this project was to develop a model to evaluate the profile of the systemic immune response developed in mice naturally exposed to Ae. aegypti mosquito bite. To do that, mice were sensitized by exposure to Ae aegypti bites and intranasally challenged with PBS or salivary gland extract (SGE) of the mosquito. Additionally, this model was compared to a classical model of allergic lung inflammation induced by sensitization and subsequent challenge with ovalbumin (OVA). After the sensitization and challenge procedures, breathing pattern, tracheal reactivity and the amount and type of cells present in bronchoalveolar lavage (BAL) were evaluated. Also, cytokines in BAL, total and specific antibodies present in serum, mucus secretion and collagen deposition in lung tissue were determined. Our results showed that mice sensitized by mosquito bites and challenged with SGE presented cellular infiltration in BAL that was dependent to the number of exposures (" $1 \mathrm{x}$ " or " $4 \mathrm{x}$ "), and mainly of mononuclear cells and eosinophils. The lymphocytic population was mainly of $\mathrm{CD}^{+}$and $\mathrm{CD} 19^{+}$cells. This qualitative cell profile was similar to the OVA group. In both groups, " $4 \mathrm{x}$ " and OVA, we observed an increase in the population of $\mathrm{T} \mathrm{CD} 4{ }^{+}$cells that produce IL-4 and IL-5 in lung and in the levels of these cytokines in BAL. Furthermore, we observed an intense mucus production by bronchial epithelial cells and little deposition of collagen around the bronchioles. Both groups showed increased levels of total IgE, specific IgG1, but only the group sensitized by bites produced significant amounts of specific IgG2a. Unlike the OVA group, mice exposed to mosquitoes showed no alterations in breathing pattern in response to methacholine. In addition, no changes were observed in the reactivity of the trachea in response to methacholine. In conclusion, our results show that the response induced by sensitization with Ae. aegypti saliva and challenge with EGS promotes a mixed response, with production antibodies of both Th1 and Th2 patterns, migration of eosinophils and mononuclear cells into the bronchoalveolar space, production of mucus in the lungs and no changes in breathing pattern and reactivity of the trachea that are common in models of pulmonary allergy.
\end{abstract}

Keywords: Allergy. Aedes aegypti. Lung inflammation. Eosinophils. Cytokines. 


\section{LISTA DE FIGURAS}

Figura 1 - Delineamento experimental do protocolo de sensibilização e desafio dos animais

Figura 2 - Estratégia de análise para avaliar a presença de neutrófilos e eosinófilos no LBA e parênquima pulmonar de camundongos sensibilizados ou não pela exposição aos mosquitos ou por OVA

Figura 3 - Estratégia de análise para avaliar a presença de células linfoides no LBA e parênquima pulmonar de camundongos sensibilizados ou não pela exposição aos mosquitos ou pela OVA

Figura 4 - Estratégia de análise para avaliar a produção de citocinas IL-4, IL-5, IL17A e IFN- $\gamma$ pela população de células T $\mathrm{CD}^{+}$

Figura 5 - Infiltrado inflamatório no LBA de camundongos expostos ou não às picadas de Ae aegypti e desafiados com PBS ou EGS

Figura 6 - Efeito da exposição e desafio com componentes salivares de Ae. aegypti no acúmulo de eosinófilos, neutrófilos, células $\mathrm{CD}^{+}{ }^{+}$e $\mathrm{CD} 19^{+}$no LBA de camundongos $\mathrm{BALB} / \mathrm{c}$

Figura 7 - Efeito da exposição e desafio com componentes salivares de Ae. aegypti no acúmulo de eosinófilos, neutrófilos, células $\mathrm{CD}^{+}$e $\mathrm{CD}_{1} 9^{+}$no parênquima pulmonar de camundongos $\mathrm{BALB} / \mathrm{c}$

Figura 8 - Comparação do infiltrado inflamatório no LBA de camundongos expostos às picadas de mosquitos Ae. aegypti ou sensibilizados com OVA s.c.

Figura 9 - Comparação do efeito da exposição e desafio com componentes salivares de Ae. aegypti ou OVA no acúmulo de eosinófilos, neutrófilos, células $\mathrm{CD}^{+}{ }^{+} \mathrm{CD} 19^{+}$no LBA de camundongos BALB/c

Figura 10 - Comparação do efeito da exposição e desafio com componentes salivares de Ae. aegypti ou OVA no acúmulo de eosinófilos, neutrófilos, células $\mathrm{CD}^{+}$e $\mathrm{CD} 19^{+}$no parênquima pulmonar de camundongos $\mathrm{BALB} / \mathrm{c}$

Figura 11 - Análise de células T CD4 $4^{+}$produtoras de IL-4, IL-5, IL-17 e IFN- $\gamma$ no parênquima pulmonar de camundongos BALB/c sensibilizados pela exposição aos mosquitos Ae. aegypti ou com OVA

Figura 12 - Concentração de citocinas no LBA de animais expostos às picadas de Ae. aegypti ou sensibilizados com OVA

Figura 13 - Determinação da concentração de anticorpos IgE total e IgG1 e IgG2a específicos no soro de animais sensibilizados com picadas do mosquito 
Ae. aegypti ou com OVA

Figura 14 - A sensibilização com picadas do mosquito Ae. aegypti não altera o padrão respiratório nem a reatividade das vias aéreas de camundongos BALB/c ... 65

Figura 15 - Infiltrado inflamatório no parênquima pulmonar de animais controles (PBS), animais desafiados com componentes salivares de Ae. aegypti (EGS) e de animais expostos às picadas de Ae. aegypti e desafiados com EGS (4x) ou sensibilizados e desafiados com OVA

Figura 16 - Produção de muco no parênquima pulmonar de animais controles (PBS), animais desafiados com componentes salivares de Ae. aegypti (EGS) e de animais expostos às picadas de Ae. aegypti e desafiados com EGS (4x) ou sensibilizados e desafiados com OVA

Figura 17 - Deposição de colágeno no parênquima pulmonar de animais controles (PBS), animais desafiados com componentes salivares de Ae. aegypti (EGS) e de animais expostos às picadas de Ae. aegypti e desafiados com EGS (4x) ou sensibilizados e desafiados com OVA

Figura 18 - Repasto sanguíneo de mosquitos Ae. aegypti fêmeas em camundongos sensibilizados 


\section{LISTA DE TABELAS}

Tabela 1 - Proteínas salivares de Aedes aegypti

Tabela 2 - Anticorpos utilizados na análise dos marcadores extracelulares por citometria de fluxo

Tabela 3 - Anticorpos utilizados na análise dos marcadores intracelulares por citometria de fluxo 


\section{LISTA DE ABREVIATURAS}

AHR - de "airway hyperreactivity" (Hiperreatividade das vias áereas)

Alum - de "Aluminum hydroxide" (Hidróxido de alumínio)

CD - de "cluster of differentiation" (Grupo de diferenciação)

CEUA - Comissão de Ética no Uso de Animais

EGS - Extrato da glândula salivar

ECP - de "eosinophil cationic protein" (Proteína catiônica do eosinófilo)

EDN - de "eosinophil-derived neurotoxin" (Neurotoxina derivada de eosinófilos)

ELISA - de “enzyme-linked immuno-sorbent assay” (Ensaio imunoenzimático)

EPO - de "Eosinophil peroxidase" (Peroxidase do eosinófilo)

HE - Hematoxilina/Eosina

ICB/USP - Instituto de Ciências Biomédicas/Universidade de São Paulo

IFN- $\boldsymbol{\gamma}$ - Interferon-gama

GM-CSF - de "Granulocyte-macrophage colony-stimulating factor" (Fator estimulador de colônias de granulócitos e macrófagos)

Ig - Imunoglobulina

IL - Interleucina 1

i.n. - Intranasal

LBA - Lavado broncoalveolar

MHC - de"major histocompatibility complex" (Complexo principal de histocompatibilidade)

MBP - de "major basic protein" (Proteína básica principal)

FACS - de "Fluorescence-Activated Cell Sorting" (Citometria de fluxo)

FSC - de "Foward Scatter" (Tamanho)

OVA - Ovalbumina

PAS - de "Periodic Acid-Schiff" (Ácido periódico de Schiff)

PBS - de "phosphate-buffered saline" (Salina tamponada com fosfato)

Penh - de "enhanced pause" (Aumento da pausa respiratória)

PMA- de "Phorbol 12-myristate 13-acetato" (Forbol 12-miristato 13-acetato)

ROS - de "reactive oxygen species" (Espécies reativas de oxigênio)

SBCAL - Sociedade Brasileira de Ciência de Animais de Laboratório

s.c. - Subcutânea

SEM - de "Standard error of the mean" (Erro padrão da média) 
SFB - Soro fetal bovino

SSC - de "Side Scatter" (Granulosidade)

Th1 - de "T helper 1" (T auxiliadora 1)

Th2 - de "T helper 2" (T auxiliadora 2)

TNF- $\alpha$ - de "Tumor necrosis factor- $\alpha$ " (Fator de necrose tumoral-alfa) 


\section{SUMÁRIO}

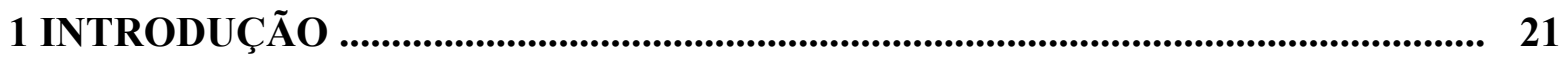

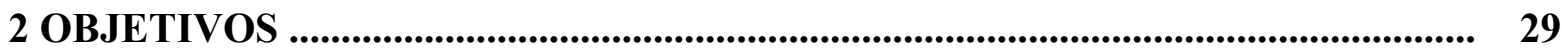

3 MATERIAL E MÉTODOS _............................................................................ 31

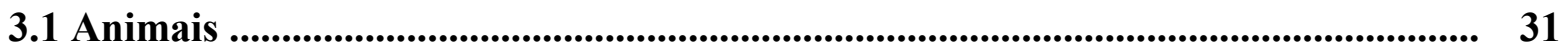

3.2 Extrato da Glândula Salivar (EGS) _............................................................................ 31

3.3 Sensibilização e desafio de camundongos com picadas de Ae. aegypti e com ovalbumina (OVA) .......................................................................................................... 32

3.4 Determinação do padrão respiratório …...................................................................... 34

3.5 Avaliação da reatividade da traqueia in vitro ........................................................... 34

3.6 Coleta de sangue ………………........................................................................................... 35

3.7 Obtenção do lavado broncoalveolar (LBA) e contagem das células ........................ 35

3.8 Digestão do tecido pulmonar para avaliações ex vivo ................................................. 36

3.9 Fenotipagem celular por citometria de fluxo (FACS) ................................................. 36

3.9.1 Marcadores de superficie ................................................................................................... 36

3.9.2 Estratégia para análise dos marcadores extracelulares .............................................. 37

3.9.3 Marcadores intracelulares em células do pulmão .................................................... 41

3.9.4 Estratégia para análise dos marcadores intracelulares ............................................... 41

3.10 ELISA para determinação de citocinas ........................................................................ 43

3.11 ELISA para determinação de anticorpos séricos ..................................................... 44

3.12 Exame histológico dos pulmões e quantificação de muco e colágeno ……………. 45

3.13 Quantificação do repasto sanguíneo ……................................................................. 46

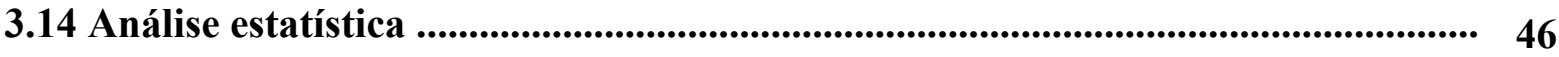

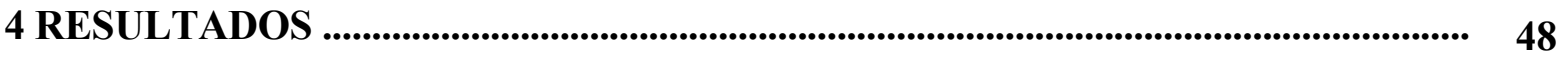

4.1 Exposição de camundongos BALB/c a picadas de mosquitos Ae. aegypti seguida por desafio intranasal com EGS induz inflamação pulmonar ............................................. 48 
4.2 Comparação dos efeitos da sensibilização pelas picadas de mosquitos Ae. aegypti com modelo murino de asma induzido por OVA.

4.2.1 Infiltrado inflamatório

4.2.2 Citocinas

4.2.3 Isotipos de anticorpos

4.2.4 Mecânica pulmonar 64

4.2.5 Histopatologia pulmonar

4.3 Avaliação do repasto sanguíneo em camundongos expostos aos mosquitos $A e$. aegypti

5 DISCUSSÃO 73

6 CONCLUSÕES 85 REFERÊNCIAS 
1 INTRODUÇÃO 
Mosquitos são artrópodes pertencentes à ordem Diptera que possui cerca de $150 \mathrm{mil}$ espécies e representa a quarta maior ordem dentro da Classe Insecta (ALVERS et al., 2010). De todas as famílias de mosquitos conhecidas, a família Culicidae é a mais importante em termos de saúde pública por conter mosquitos dos gêneros Aedes, Culex e Anopheles, que são os principais artrópodes vetores de parasitas causadores de diversas doenças humanas. Nesse contexto, Aedes aegypti é a espécie mais bem caracterizada e, em áreas de clima tropical, é conhecida por ser vetor primário de doenças emergentes e re-emergentes como a febre amarela, febre Chikungunya e dengue (CHEN et al., 2008; CURTIS; GRAVES, 1988; REUNALA et al., 1990).

Os mosquitos Ae. aegypti fêmeas precisam de sangue para garantir o desenvolvimento de seus ovos e para se alimentar com sucesso, necessitam localizar vasos sanguíneos de seus hospedeiros vertebrados. Nesse processo, o primeiro desafio encontrado após a ruptura física da pele é a barreira da hemostasia (SÁ-NUNES; OLIVEIRA, 2010). A hemostasia é um processo fisiológico complexo e redundante do qual fazem parte a coagulação sanguínea, agregação plaquetária e vasoconstrição, capazes de estancar a hemorragia no local de um ferimento, mas mantendo o fluxo sanguíneo normal no restante da circulação (GALE, 2011). Durante a evolução junto aos seus hospedeiros, os artrópodes hematófagos desenvolveram um coquetel salivar com componentes anticoagulantes, antiagregante de plaquetas e vasodilatadores que neutralizam os efeitos da hemostasia e permitem que uma alimentação sanguínea bem sucedida ocorra (RIBEIRO, 1987; RIBEIRO, 2000; REUNALA et al., 1990).

A agregação de plaquetas é a primeira linha de defesa para evitar a perda de sangue após lesão do tecido. As plaquetas ativadas por diversos agonistas, incluindo a trombina, o colagénio e ADP (adenosina difosfato), agregam-se no local da injúria, promovendo a coagulação e liberação de substâncias vasoconstritoras para formar o tampão de plaquetas. Insetos hematófagos bloqueiam a agregação plaquetária por diferentes mecanismos, mas a hidrólise do ADP parece ser a estratégia mais utilizada (VALENZUELA, 2002). Atividade apirase foi demonstrada na saliva de alguns mosquitos, resultando em inibição da agregação plaquetária pela hidrólise de ATP (adenosina trifosfato) e ADP liberados por células lesadas ou plaquetas ativadas. Através desse processo ocorre a liberação de AMP (adenosina monofosfato) e fosfato inorgânico que são incapazes de agregar plaquetas (RIBEIRO et al., 1984). Posteriormente essa enzima foi caracterizada como um membro da família de genes da 5'-nucleotidase (CHAMPAGNE et al., 1995). A aegyptina, um membro da família de alérgenos de $30 \mathrm{kDa}$, liga-se especificamente ao colágeno e bloqueia a agregação de plaquetas induzida por essa proteína (CALVO et al., 2007). Além disso, a aegyptina também inibe a 
interação do fator de von Willebrand ao colágeno do tipo III sob condições estáticas assim como a adesão de plaquetas ao colágeno sob condições de fluxo de alta velocidade (CALVO et al., 2007).

O aumento do fluxo sanguíneo foi observado nos locais dos braços de voluntários humanos onde o mosquito Ae. aegypti havia se alimentado, sugerindo assim a presença de um componete vasodilatador na saliva deste inseto (PAPPAS et al., 1986 apud RIBEIRO, 1992). Os vasodilatadores são moléculas que aumentam o fluxo sanguíneo, antagonizando vasoconstritores produzidos pelo sistema hemostático após lesão do tecido pelo aparelho bucal dos insetos. Em 1992 foi descoberto que a atividade vasodilatadora de Ae. aegypti devese as sialocininas I e II, peptídeos da família das taquicininas. As sialocininas agem diretamente sobre o endotélio ativando a produção de óxido nítrico, resultando na vasodilatação (CHAMPAGNE; RIBEIRO, 1994; RIBEIRO, 1992).

A cascata de coagulação consiste em uma série de serino-proteases que ativam umas às outras de forma sequencial. Este processo culmina na produção de trombina ativa, que cliva o fibrinogênio em fibrina, que por sua vez se polimeriza e, juntamente com as plaquetas, forma o coágulo de sangue. Os componentes anticoagulantes presentes na saliva de artrópodes hematófagos agem especificamente em proteases ou complexos envolvidos na coagulação sanguínea, como a trombina e o fator Xa (VALENZUELA, 2002). Substâncias com propriedades anticoagulantes isoladas da saliva de insetos já foram descritas e no caso específico do mosquito Ae. aegypti foi encontrado um inibidor de serino-proteases (serpina) que atua sobre o fator Xa (AFXa - Anticoagulant-Factor Xa) com atividade anti-coagulante (STARK; JAMES, 1995, 1998). O possível papel anticoagulante e anti-inflamatório de uma outra serpina de Ae. aegypti encontrada no salivoma da espécie, provisoriamente chamada de AET-7393, está sendo investigada por nosso grupo no momento.

No entanto, o papel da saliva na hematofagia não se limita apenas ao sistema vascular. Uma resposta inflamatória mensurável é observada nos hospedeiros após a picada de mosquitos e trabalhos clássicos demonstraram que a secreção salivar é a responsável pela sensibilização a essas picadas. Já foi demonstrado que antígenos salivares estão envolvidos na elicitação de reações imediatas e tardias na pele dos hospedeiros (HECHT, 1928; MCKIEL, 1959). Por outro lado, quando o duto salivar de fêmeas de Ae. aegypti foi cortado, esses mosquitos ainda foram capazes de se alimentar e realizar postura de ovos, mas as reações cutâneas associadas às picadas em hospedeiros sensibilizados não ocorreram (HUDSON et al., 1960). De fato, muitos dos componentes salivares são imunogênicos e induzem respostas imunes evidentes, como o inchaço e coceira que acompanham uma picada de mosquito 
(PENG; SIMONS, 2007). Porém, após exposições repetidas aos antígenos salivares, o sistema imune do hospedeiro pode elaborar reações celulares ou humorais que alteram o microambiente e, caso essas reações sejam suficientemente fortes, elas podem afetar a capacidade dos mosquitos de se alimentar e/ou de se reproduzir. Este fato foi comprovado pela imunização de coelhos com um extrato total de Ae. aegypti, que causou uma redução de 24 a $31 \%$ na fecundidade dos mosquitos fêmeas que se alimentaram nesses animais (SUTHERLAND; EWEN, 1974).

A evolução dos componentes salivares de artrópodes hematófagos pode ter ocorrido no sentido de tentar contornar este problema. Tal fato pode ser observado pela presença de fatores salivares que evitam a sensibilização dos hospedeiros pelos fatores vasoconstritores que facilitam a alimentação ou retardam respostas deletérias por parte do hospedeiro (ANDRADE et al., 2005; GILLESPIE et al., 2000). Tais fatores induzem um desvio da resposta para Th2, o que parece favorecer a sobrevivência de ectoparasitas. Muitas atividades imunomoduladoras já foram demonstradas na saliva de diferentes espécies de artrópodes hematófagos, atuando direta ou indiretamente em células imunes efetoras como células dendríticas, macrófagos e células T, mas apenas em alguns casos as moléculas responsáveis por tais atividades foram descritas (ANDRADE et al., 2005; SÁ-NUNES; OLIVEIRA, 2010). No caso específico do Ae. aegypti, foi demonstrado que o extrato da glândula salivar (EGS) do mosquito inibe a liberação de TNF- $\alpha$ em monocultura de mastócitos de rato, mas não afeta a desgranulação dessas células (BISSONNETTE et al., 1993). O EGS de Ae. aegypti também inibe a proliferação in vitro de linfócitos de camundongo induzida por concanavalina A (WASSERMAN et al., 2004) e antígeno-específica (CROSS et al., 1994; WASSERMAN et al., 2004). Essa inibição foi acompanhada por uma redução de citocinas pró-inflamatórias (GM-CSF e TNF- $\alpha$ ) e citocinas do perfil Th1 (IL-2 e IFN- $\gamma$ ), mas pouco efeito foi observado nos níveis das citocinas Th2, IL-4 e IL-5 (WASSERMAN et al., 2004). Nosso grupo recentemente demonstrou que o EGS de Ae. aegypti não afeta a diferenciação, maturação ou função das células dendríticas e que seu efeito inibitório sobre a proliferação de linfócitos T se dá pela indução de apoptose nessas células (BIZZARRO, 2012). Até mesmo durante infecções virais, a saliva dos insetos hematófagos pode agir na regulação do sistema imune. A presença da saliva de Ae. aegypti em inóculos com o vírus Sindbis resultou em uma redução local da citocina IFN- $\gamma$ e aumento das citocinas IL-4 e IL-10, em comparação com a injeção do vírus somente (SCHNEIDER et al., 2004). O mesmo foi observado quando a produção sistêmica de citocinas foi avaliada a partir de linfócitos esplênicos coletados de camundongos susceptíveis aos flavivírus expostos as picadas de Culex quinquefasciatus e Ae. aegypti 
(ZEIDNER et al., 1999). Nestes experimentos também foi observada a redução de IFN- $\gamma$ e aumento de IL-4 e IL-10, resposta que propicia a infecção viral.

Como visto até aqui, a saliva de mosquitos possui uma série de efeitos biológicos em seus hospedeiros, embora o conhecimento das moléculas responsáveis por essas atividades ainda esteja em uma fase bastante inicial. Para se ter uma ideia, até o ano de 2002 estavam depositadas no GenBank sequências de apenas 6 proteínas conhecidamente expressas nas glândulas salivares de Ae. aegypti: amilase (GROSSMAN; JAMES, 1993), alfa-1,4 glicosidase (JAMES et al., 1989), apirase (CHAMPAGNE et al., 1995), proteína D7 (JAMES et al., 1991), alérgeno de 30 kDa (SIMONS; PENG, 2001) e sialocinina (BEERNTSEN et al., 1999). Com a publicação do primeiro salivoma da espécie nesse mesmo ano, 32 novos transcritos completos (full-length) foram sequenciados, 31 deles possuindo um provável peptídeo sinal indicativo de secreção. Desse total, dez proteínas foram encontradas por degradação de Edman em bandas visíveis em gel de eletroforese (SDS-PAGE) de um homogeneizado de 80 pares de glândulas de fêmeas adultas de Ae. aegypti (VALENZUELA et al., 2002). Após a publicação do genoma dessa espécie (NENE et al., 2007) e com o uso de programas de bioinformática, a busca por novas proteínas foi facilitada e no segundo salivoma publicado 5 anos mais tarde foram sequenciados 573 novos transcritos, 136 desses codificando proteínas provavelmente secretadas (RIBEIRO et al., 2007). Mais de 20 dessas proteínas foram confirmadas em um gel de eletroforese bidimensional de EGS de fêmeas de Ae. aegypti, utilizando digestão tríptica e espectometria de massa (RIBEIRO et al., 2007). Essas proteínas foram agrupadas em aproximadamente 40 famílias e possuem, em sua maioria, função desconhecida. Algumas dessas proteínas foram estudadas por Peng e Simons (2004) e uma das tabelas desse trabalho apresentando as características de diversos componentes salivares de Ae. aegypti é reproduzida a seguir (Tabela 1). As proteínas caracterizadas como alérgenos estão indicadas por setas vermelhas na tabela. 
Tabela 1 - Proteínas salivares de Aedes aegypti.

\begin{tabular}{|c|c|c|c|c|}
\hline Protein name & $\begin{array}{l}\text { Allergen } \\
\text { name }\end{array}$ & $\begin{array}{l}\text { Molecular } \\
\text { weight (KD) }\end{array}$ & $\begin{array}{l}\text { cDNA } \\
\text { sequenced }\end{array}$ & $\begin{array}{l}\text { Biological } \\
\text { functions }\end{array}$ \\
\hline$\alpha$-Amylase 1 & $?$ & 81.5 & yes & unknown \\
\hline Apyrase & $\rightarrow$ Aed a 1 & 68 & yes & antiplatelet \\
\hline$\alpha$-Glucosidase (maltase-like 1) & $\rightarrow$ Aed a 4 & 67 & yes & sugar digestion \\
\hline Esterase & $?$ & 65 & $?$ & unknown \\
\hline Anticoagulant-factor $\mathrm{Xa}$ & $?$ & 54 & yes & anticoagulant \\
\hline Aed a $X_{1}$ & Aed a $X_{1}$ ? & 44 & $?$ & unknown \\
\hline Aed a $\mathrm{X}_{2}$ & Aed a $\mathrm{X}_{2}$ ? & 37 & $?$ & unknown \\
\hline Female-specific protein, D7 & $\rightarrow$ Aed a 2 & 37 & yes & unknown \\
\hline- & $\rightarrow$ Aed a 3 & 30 & yes & unknown \\
\hline Sialokinins & $?$ & 1.4 & yes & vasodilator \\
\hline Anti-tumour necrosis factor & $?$ & unknown & $?$ & $\begin{array}{l}\text { anti-tumour } \\
\text { necrosis factor }\end{array}$ \\
\hline Lysozyme & $?$ & unknown & $?$ & bacteriolysis \\
\hline
\end{tabular}

Fonte: Adaptada de PENG e SIMONS (2004).

Durante seu repasto sanguíneo, os mosquitos injetam saliva na pele do hospedeiro, o que parece sensibilizar tanto o homem quanto outros animais (MCKIEL, 1959). Para estudar as consequências dessa exposição, Mellanby (1946) expôs ao Ae. aegypti, 25 voluntários que nunca tinham entrado em contato com esse mosquito e observou que as primeiras picadas não causaram nenhuma reação inicial visível, mas picadas subsequentes induziram uma lesão cutânea tardia. Depois de repetidas picadas que ocorreram ao longo de um mês, foi observado o desenvolvimento tardio de uma pápula e, após exposições subsequentes por vários meses, essas reações desapareceram. De forma geral, esse trabalho mostrou que as picadas de mosquitos causam reações cutâneas locais imediatas e tardias, que ocasionalmente ocorrem reações sistêmicas e que a dessensibilização ocorre após exposições repetidas. Entretanto, não é possível afirmar que essa sequência de eventos ocorra nas pessoas expostas naturalmente ao mosquito (PENG; SIMONS, 2004). Isso porque na vida real, a sensibilização natural pode levar anos para ocorrer ou pode nunca ocorrer, pois as pessoas geralmente evitam a exposição aos mosquitos quando isso é possível.

Segundo Simons et al. (2003), apenas reações que causam alterações grandes ou atípicas podem ser descritas como "alergia a mosquito". Em alguns casos, foram relatadas reações sistêmicas incluindo urticária generalizada e anafilaxia e também alterações locais graves como a "Síndrome de Skeeter" (SIMONS; PENG, 1999; PENG et al., 2004). A "Síndrome de Skeeter" é definida como uma intensa reação inflamatória local induzida pela picada de mosquito e, por vezes, acompanhada de febre (PENG et al., 2004). Os mecanismos 
envolvidos em reações alérgicas são bem descritos, embora as causas que levam ao desenvolvimento de alergia, processo chamado de sensibilização, ainda não estejam totalmente elucidadas. Pelo que se sabe até o momento, após a sensibilização alérgica, as células $\mathrm{T}$ de pacientes atópicos tendem a produzir níveis elevados de citocinas do perfil Th2 que regulam a síntese de IgE, como a interleucina 4 (IL-4), a proliferação e infiltração de eosinófilos nas vias aéreas (IL-5), proliferação de mastócitos (IL-9) e produção de muco e hiperresponsividade das vias aéreas (IL-13). Um padrão Th2 de expressão de citocinas é observado em inflamações alérgicas e em infecções parasitárias, condições que estão associadas com a produção de IgE e eosinofília (HAMELMANN; GELFAND, 2001; HOLGATE; POLOSA, 2008). Embora quase metade da população urbana mundial seja atópica (geneticamente predispostas a produzir anticorpos IgE no soro) e a maioria dos doentes alérgicos sejam atópicos, é possível que haja o desenvolvimento de alergia na ausência de atopia, como pode ser observado nos casos de alergias a vespas e abelhas, por exemplo (HOLGATE; POLOSA, 2008).

Diversos modelos experimentais capazes de reproduzir algumas das características da resposta alérgica estão descritos na literatura, incluindo infestação por helmintos e inoculação de diversas moléculas e extratos (ROGERIO et al., 2010). Assim, os modelos murinos forneceram grande parte do que já se sabe sobre o desenvolvimento de alergias, em especial a asma (EPSTEIN, 2004). Modelos animais que mimetizam as características imunológicas e da inflamação pulmonar observadas na asma humana são ferramentas importantes para estudar de maneira aprofundada os mecanismos celulares e moleculares que envolvem o início e controle da alergia (BAQUEIRO et al., 2010). Nesse sentido, o modelo experimental de asma alérgica induzida por ovalbumina (OVA) é um dos mais bem caracterizados. Embora existam algumas diferenças com relação à doença humana, camundongos sensibilizados e desafiados com OVA desenvolvem inflamação eosinofilica pulmonar, hiperreatividade das vias aéreas, aumento dos níveis de IgE, hipersecreção de muco e, ocasionalmente, o remodelamento das vias aéreas (EPSTEIN, 2004).

$\mathrm{Na}$ resposta às picadas de mosquitos, algumas das características observadas em humanos também podem ser reproduzidas em modelos murinos após sensibilização natural pela picada de mosquitos ou após sensibilização realizada com alérgenos recombinantes. Como resultado, foi observada a produção de anticorpos específicos contra componentes da saliva, desenvolvimento de reações cutâneas e dessensibilização, assim como observado em seres humanos (CHEN et al., 1998). Uma vantagem da sensibilização natural é a ausência do uso de adjuvantes, mimetizando a alergia que uma parcela crescente da população desenvolve durante a 
vida. Neste sentido, o modelo de sensibilização natural à picada de mosquito pode ser uma ótima ferramenta de estudo, pois permite que sejam avaliados vários parâmetros da resposta imune induzida pela saliva, ao mesmo tempo em que também pode ser utilizado para estudos mais aprofundados de doenças alérgicas, assim como dos mecanismos envolvidos nos processos de sensibilização e dessensibilização aos alérgenos. 
2 OBJETIVOS 
O objetivo deste trabalho foi caracterizar um modelo murino de inflamação pulmonar alérgica em camundongos expostos naturalmente às picadas de mosquitos Ae. aegypti. Para tanto, tivemos como objetivos específicos:

1- Caracterizar o perfil da inflamação pulmonar induzida pela sensibilização e desafio com componentes salivares de Ae. aegypti;

2- Comparar esse perfil com um modelo bem estabelecido de asma experimental em camundongos. 
3 MATERIAL E MÉTODOS 
O delineamento experimental deste projeto se pautou nas recomendações dos Princípios Éticos de Experimentação Animal adotado pela Sociedade Brasileira de Ciência de Animais de Laboratório (SBCAL) e foi aprovado pela Comissão de Ética no Uso de Animais (CEUA) do Instituto de Ciências Biomédicas da USP, cujos pareceres foram registrados sob o número 140, na folha 111 e sob o número 148, na folha 111 do livro 02 para uso de animais em experimentação.

\subsection{Animais}

Foram utilizados camundongos BALB/c fêmeas com idade entre 6 e 8 semanas, fornecidos pelo Biotério de Camundongos Isogênicos do Departamento de Imunologia do Instituto de Ciências Biomédicas da Universidade de São Paulo - ICB/USP. Antes e após a manipulação, os animais foram mantidos no biotério, acondicionados em caixas coletivas contendo no máximo cinco animais por caixa, sob condições controladas de temperatura e luminosidade e alimentação e água ad libitum.

\subsection{Extrato da Glândula Salivar (EGS)}

Machos e fêmeas de mosquitos Ae. aegypti foram mantidos no biotério de insetos do Departamento de Parasitologia do Instituto de Ciências Biomédicas da USP, onde foram alimentados e acasalados. Glândulas salivares de fêmeas de Ae. aegypti com 3-5 dias após emergência foram dissecadas em PBS e transferidas para um pequeno tubo contendo $100 \mu \mathrm{L}$ de PBS gelado estéril. Os tubos foram sonicados para liberação do material solúvel das glândulas e em seguida foram centrifugados a $14.000 \mathrm{~g}$ por 10 min a $4{ }^{\circ} \mathrm{C}$ para remoção do material particulado. O sobrenadante resultante de cada tubo, referido como extrato da glândula salivar (EGS), foi reunido e esterilizado por passagem através de uma membrana de nitrocelulose com poros de 0,2 $\mu \mathrm{m}$ (Millex Millipore, Carrigtwohill, County Cork, Irlanda). A concentração proteica foi determinada em NanoDrop 2000 (Thermo Fisher Scientific, Wilmington, DE, USA) e o material foi aliquotado e armazenado a $-80{ }^{\circ} \mathrm{C}$ até o momento de uso. 


\subsection{Sensibilização e desafio de camundongos com picadas de Ae. aegypti e com ovalbumina (OVA)}

Para o protocolo de sensibilização pelas picadas de Ae. aegypti, camundongos BALB/c foram submetidos a um protocolo de alta infestação com o mosquito, padronizado em nosso laboratório. Para isso, os animais foram divididos em dois grupos e identificados de acordo com o número de vezes que foram expostos aos mosquitos (1 ou 4 vezes - Figura 1). Os camundongos foram anestesiados por inoculação intramuscular de acepromazina $(0,1$ $\mathrm{mg} / \mathrm{kg})$ e xilazina $(0,8 \mathrm{mg} / \mathrm{kg})$ e expostos a aproximadamente 50 fêmeas de Ae. aegypti por 30 minutos. Esse procedimento foi realizado 1 ou 4 vezes dependendo do grupo, com intervalo de 14 dias entre cada exposição (dias 0, 14, 28 e 42) e o protocolo foi sincronizado de modo que a primeira sensibilização dos grupos ocorresse no mesmo dia. Grupos de animais de mesma idade e sexo, não expostos ao mosquito, foram mantidos como controle do experimento.

Para indução de inflamação alérgica pulmonar, os animais sensibilizados foram desafiados pela via intranasal (i.n.) com EGS de Ae. aegypti nos dias 49 e 56 conforme descrição a seguir. Utilizando uma micropipeta (Eppendorf, São Paulo, SP, Brasil), $50 \mu \mathrm{L}$ de uma solução de PBS estéril contendo $10 \mu \mathrm{g}$ de EGS foram gotejados nas narinas até sua completa aspiração (grupos "1x" e "4x"). Um grupo de animais não sensibilizado foi também desafiado i.n. nos dias 49 e 56 da mesma maneira (grupo "EGS"), enquanto um grupo controle recebeu nesses mesmos dias apenas com $50 \mu \mathrm{L}$ de PBS estéril i.n. (grupo "PBS").

Em alguns experimentos, foi também incluído um grupo de animais sensibilizados e desafiados com ovalbumina (grupo "OVA"). Este protocolo foi sincronizado de modo que os desafios de todos os grupos ocorressem nos mesmos dias. Assim, os animais do grupo "OVA" foram sensibilizados pela via subcutânea (s.c.) nos dias 35 e 42 com $4 \mu \mathrm{g}$ de OVA (Grau II Sigma, St Louis, MO, USA) diluída em PBS e adsorvida em 1,6 mg de hidróxido de Alumínio (Alum) (Sigma). Nos dias 49 e 56, os animais sensibilizados foram desafiados pela via intranasal (i.n.) com $10 \mu \mathrm{g}$ de OVA diluídos em $50 \mu \mathrm{L}$ de PBS estéril, da mesma maneira descrita para o EGS (BORTOLATTO et al., 2008; FAUSTINO et al., 2012).

Vinte e quatro horas após o primeiro desafio, o padrão respiratório e a reatividade da traqueia desses animais foram analisados, conforme descrito nos itens 3.4 e 3.5. Os animais foram submetidos à eutanásia $24 \mathrm{~h}$ após o segundo desafio para coleta de tecidos, sangue e fluídos (Figura 1). 
Figura 1 - Delineamento experimental do protocolo de sensibilização e desafio dos animais.

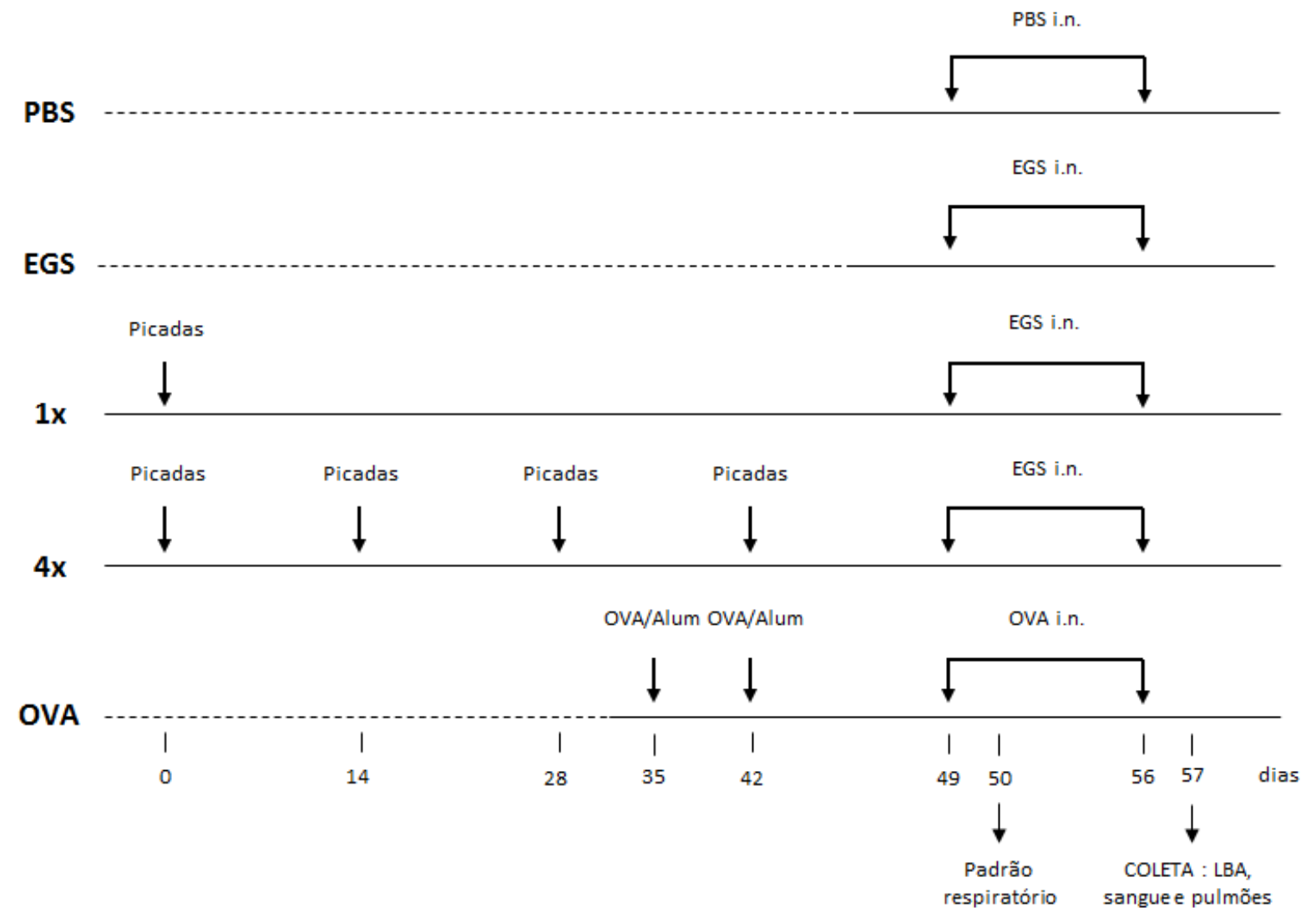

Entre os dias 0 a 42 os animais dos grupos " $1 \mathrm{x}$ " $\mathrm{e}$ " $4 \mathrm{x}$ " foram sensibilizados (50 mosquitos/camundongo) conforme a quantidade de exposições determinada para cada grupo. Os animais dos grupos " $1 \mathrm{x}$ " e " $4 \mathrm{x}$ " foram desafiados duas vezes (dias 49 e 56) com EGS i.n. Os animais dos grupos "PBS" e "EGS" não foram sensibilizados, mas receberam PBS e EGS, respectivamente, nos mesmos dias i.n. (dias 49 e 56). Os animais do grupo "OVA" foram sensibilizados s.c. com OVA adsorvida em Alum nos dias 35 e 42 e desafiados com OVA i.n. nos dias 49 e 56. A avaliação do padrão respiratório foi realizada no dia 50 e a reatividade de traqueia, coleta de LBA, sangue e pulmão no dia 57 , sempre 24 horas após os desafios. 


\subsection{Determinação do padrão respiratório}

O padrão respiratório dos animais foi avaliado $24 \mathrm{~h}$ após o primeiro desafio antigênico, no Laboratório de Imunobiologia, Departamento de Imunologia do ICB/USP, coordenado pelo Prof. Dr. Momtchilo Russo. Para isso, animais conscientes e livres foram colocados em câmaras pletismográficas (whole-body plethysmograph - Buxco Eletronics Inc., Wilmington, NC, USA). Para avaliar a responsividade pulmonar dos camundongos à metacolina, os parâmetros respiratórios foram medidos por 5 minutos após nebulização com PBS e novamente após nebulização com 12 e $25 \mathrm{mg} / \mathrm{mL}$ de metacolina (Sigma). A metacolina é um agonista colinérgico que age diretamente sobre os receptores de acetilcolina no músculo liso provocando contração e estreitamento das vias aéreas. Por ter alta sensibilidade para identificar responsividade das vias aéreas, a metacolina tem sido amplamente utilizada nesse tipo de ensaio, tanto experimentalmente quanto na prática clínica (ANDERSON et al., 2009; RUBIN, 2002).

Para realizar o cálculo que expressa o padrão respiratório de cada animal, foi utilizado o aumento na pausa respiratória $(P e n h)$, calculado pela seguinte fórmula:

$$
\text { Penh }=(T e / T r 1) \times \text { Pef } / \text { Pif }
$$

onde $\boldsymbol{P e n h}$ é o aumento da pausa respiratória; $\boldsymbol{T} \boldsymbol{e}$ é o tempo expiratório (s); $\boldsymbol{T r}$, tempo de relaxamento; Pef, o pico de fluxo expiratório e Pif, o pico de fluxo inspiratório. Todos os cálculos dos valores do Pehn foram realizados pelo software de análise Biosystem XA para Windows (Buxco Eletronics).

Os resultados foram expressos na forma de média dos valores de Penh obtidos com as diferentes concentrações de metacolina ou sob a forma de área sob a curva da dose-resposta à metacolina.

\subsection{Avaliação da reatividade da traqueia in vitro}

$\mathrm{O}$ ensaio de reatividade de musculatura lisa em tecido isolado foi realizado no Laboratório de Fisiopatologia da Inflamação Experimental, Departamento de Farmacologia do ICB/USP, coordenado pelo Prof. Dr. Wothan Tavares de Lima. Para tanto, grupos de camundongos $(n=8)$ foram eutanasiados por excesso de anestésico (pentobarbital sódico; > $360 \mathrm{mg} / \mathrm{kg}$ i.p.) e exsanguinados. A seguir, o tórax foi aberto e a traqueia removida e montada 
para registro isométrico de contrações em resposta à estimulação colinérgica (metacolina). Para tanto, foi utilizado um sistema multicanal de tecido isolado (Powerlab ${ }^{\circledR}$, ADInstruments, Colorado Springs, CO, USA) acoplado a um sistema de aquisição, análise e estocagem de dados (Lab chart 7.01, ADInstrumensts). Os segmentos de traqueia foram montados em cubas para órgão isolado $(15 \mathrm{ml})$ contendo solução de Krebs-Henseleit, com a seguinte composição (mM): $\mathrm{NaCl}, 115 ; \mathrm{KCl}, 4.6 ; \mathrm{CaCl}_{2} 2 . \mathrm{H}_{2} 0,2,5 ; \mathrm{KH}_{2} \mathrm{PO}_{4}, 1,2 ; \mathrm{MgSO}_{4} 7 \mathrm{H}_{2} 0,2,5 ; \mathrm{NaHCO}_{3}, 25$; glicose, 11 ; aerada com $95 \%$ de $\mathrm{CO}_{2}, 5 \%$ de $\mathrm{O}_{2}$ e aquecida a $37^{\circ} \mathrm{C}$. Os segmentos de traqueia foram submetidos a uma carga inicial de 0,5 g de tensão. Após a carga inicial, o tecido permaneceu em repouso por um período de 40 minutos para a estabilização. Decorrido esse período, a tensão foi reajustada para $0,5 \mathrm{~g}$ e a capacidade contrátil (viabilidade tecidual) foi avaliada substituindo o tampão Krebs-Henseilet por tampão $\mathrm{KCl}$ despolarizante $(60 \mathrm{mM})$. Após a avaliação da viabilidade das preparações, o $\mathrm{KCl}$ foi substituído novamente pelo tampão Krebs-Henseilet. Decorridos 20 minutos de equilíbrio foram administradas nas cubas doses crescentes de metacolina $\left(10^{-9}\right.$ a $\left.10^{-3} \mathrm{M}\right)$ para construção das curvas concentração-efeito (LINO-DOS-SANTOS-FRANCO et al., 2006).

\subsection{Coleta de sangue}

Vinte e quatro horas após o último desafio (dia 57), os camundongos foram anestesiados profundamente por meio de injeção intraperitoneal (i.p.) de uma solução contendo hidrato de cloral 10\% (600 mg/Kg) (Labsynth, São Paulo, SP, Brasil) e cetamina (34 mg/Kg) (Syntec, Cotia, SP, Brasil). Em seguida o sangue foi coletado por punção cardíaca, o soro foi separado e armazenado a $-80{ }^{\circ} \mathrm{C}$ até momento de uso.

\subsection{Obtenção do lavado broncoalveolar (LBA) e contagem das células}

Após coleta do sangue, os animais tiveram a traqueia exposta, canulada e com o auxílio de uma seringa, a coleta do LBA foi realizada por meio da lavagem dos pulmões com $1 \mathrm{~mL}$ de PBS gelado inoculado no espaço broncoalveolar e aspirado em seguida. As células foram colocadas em tubos de polipropileno de fundo cônico e mantidas no gelo.

Para a contagem total, uma alíquota da suspensão de células foi diluída na proporção de 1:1 em corante de Turk (Solução de 3\% de ácido acético e $4 \mathrm{mg} / \mathrm{L}$ de Violeta de Genciana). O número total de células presentes no LBA de cada animal foi determinado em 
câmara de Neubauer e para a contagem diferencial, foram preparadas lâminas em citocentrífuga (BIO Research, São Paulo, SP, Brasil) a partir de suspensão contendo 4 × $10^{4}$ células em $200 \mu \mathrm{L}$. Em seguida, as lâminas foram coradas com o kit corante hematológico "3 Step Staining Set” (Richard-Allan Scientific, Kalamazoo, MI, USA). Células mononucleares, eosinófilos e neutrófilos foram identificados segundo coloração e características morfológicas. Com o auxílio de um microscópio óptico, foram contadas 100 células por lâmina utilizando objetiva de imersão (aumento final de 1000×). Após realização da contagem diferencial, o número total de cada tipo celular foi calculado em função de sua porcentagem em relação ao número total de células.

\subsection{Digestão do tecido pulmonar para avaliações ex vivo}

Após a coleta do LBA, o pulmão foi perfundido via ventrículo direito do coração com PBS e o lobo médio do pulmão direito de cada camundongo foi coletado. Para a separação das células do parênquima pulmonar, o pulmão de cada animal foi digerido em uma solução contendo $2 \mathrm{mg} / \mathrm{mL}$ de colagenase tipo IV (Sigma) e $1 \mathrm{mg} / \mathrm{mL}$ de desoxirribonuclease 1 (DNAse) (Sigma) em PBS estéril e incubados em banho-maria a $37{ }^{\circ} \mathrm{C}$ por 30 minutos. Em seguida, o volume da solução de digestão foi ajustado para $10 \mathrm{ml}$ com PBS/SFB 10\% estéril e os órgãos foram macerados em um homogeneizador do tipo "POTTER". A solução de células foi centrifugada e, após descarte do sobrenadante, as hemácias presentes na suspensão foram lisadas com $2 \mathrm{~mL}$ de solução de lise (Invitrogen, Carlsbad, CA, USA). Após nova lavagem com PBS/SFB 10\%, as células foram ressuspendidas em $2 \mathrm{~mL}$ de meio de cultura RPMI completo (RPMI 1640 suplementado com 10\% de SFB, 2 mM de L-glutamina, 100 unidades/mL penicilina, $100 \mu \mathrm{g} / \mathrm{mL}$ de estreptomicina, $25 \mathrm{mM}$ de Hepes, $2,5 \times 10^{-5} \mathrm{M} 2-$ mercaptoetanol), contadas e a suspensão final foi ajustada para $1 \times 10^{7}$ células $/ \mathrm{mL}$.

\subsection{Fenotipagem celular por citometria de fluxo (FACS)}

\subsubsection{Marcadores de superficie}

Para a marcação das células do LBA e do parênquima pulmonar, as mesmas foram centrifugadas e ressuspendidas a $10^{6}$ células $/ \mathrm{mL}$ e $10^{7}$ células $/ \mathrm{mL}$, respectivamente, em tampão de FACS (PBS contendo 1\% de SFB). Alíquotas de $100 \mu \mathrm{L}$ de cada suspensão foram transferidas para placas de 96 poços de fundo em "U" e incubadas por 15 min a $4{ }^{\circ} \mathrm{C}$ com 
anticorpo anti-CD16/CD32 (diluição final 1:1000) para bloqueio dos receptores Fc presentes em fagócitos. Em seguida, as células foram incubadas por $30 \mathrm{~min}$ a $4{ }^{\circ} \mathrm{C}$ e protegidas da luz, com os anticorpos monoclonais anti-camundongo para os marcadores de superfície em diluições apropriadas, como descrito na Tabela 1. Após lavagem, as células foram transferidas para tubos de polipropileno de $12 \times 75 \mathrm{~mm}$ e as amostras foram adquiridas no citômetro FACSCalibur (BD Biosciences, San Juan, CA, USA), do Serviço de Citometria do Departamento de Imunologia do ICB. A análise dos resultados foi realizada pelo software FlowJo, versão 7.5.5 (TreeStar Inc., Ashland, OR, USA).

Tabela 2 - Anticorpos utilizados na análise dos marcadores extracelulares por citometria de fluxo.

\begin{tabular}{ccc}
\hline Anticorpo & Fluorocromo & Diluição \\
\hline anti-mouse CD8a & FITC & $1: 100$ \\
anti-mouse CD4 & APC & $1: 1600$ \\
anti-mouse CD19 & PE & $1: 200$ \\
anti-mouse Ly-6G (Gr-1) & FITC & $1: 200$ \\
anti-mouse MHC class II (I-A/I-E) & APC & $1: 800$ \\
anti-mouse Siglec-F & PE & $1: 200$ \\
\hline
\end{tabular}

\subsubsection{Estratégia para análise dos marcadores extracelulares}

Nas Figuras 3 e 4 apresentamos a estratégia de "gating" utilizada nos experimentos de separação de eosinófilos, neutrófilos e células CD4 $4^{+}$e CD19 ${ }^{+}$.

Para análise das células mielóides presentes no parênquima pulmonar, foi feita, primeiramente, a exclusão de células potencialmente mortas e debris celulares que normalmente aparecem na região inferior esquerda da representação em "dot plot", que mostra o tamanho dos eventos (FSC) e a complexidade interna ou granulosidade (SSC) (Figura 2A). Para eliminar a autofluorescência comum nesses casos, um canal do citômetro que não estava sendo utilizado na análise permaneceu aberto durante todas as aquisições, ou seja, não havia nenhum fluorocromo para ser detectado nesse canal (FL3-H). As células também foram analisadas em função da expressão de moléculas de MHC classe II (I-A/I-E) em sua superfície e os eventos que não apresentavam fluorescência para esses dois canais (IA/I-E e FL3-H) foram então selecionadas (Figura 2B) e analisadas em função da expressão de 
Siglec-F e Gr-1 na sua superfície (Figura 2C). Trabalhos da literatura demonstraram que usando essa estratégia de análise, a população Siglec-F positiva/Gr-1 intermediária (Siglec$\mathrm{F}^{+} / \mathrm{Gr}^{-1}{ }^{\mathrm{INT}}$ ) são eosinófilos e a população Siglec-F negativa/Gr-1 high (Siglec-F- $/ \mathrm{Gr}-1^{\mathrm{HI}}$ ) são neutrófilos (HAMMAD et al., 2010; OHNMACHT et al., 2010).

Para análise dos marcadores CD4 e CD19, foi feita a eliminação das células potencialmente mortas (Figura 3A) e a exclusão dos eventos autofluorescentes (Figura 3B) como já descrito e então avaliada a expressão das moléculas CD4 e CD19 em sua superfície (Figura 3C). 
Figura 2 - Estratégia de análise para avaliar a presença de neutrófilos e eosinófilos no LBA e no parênquima pulmonar de camundongos sensibilizados ou não pela exposição aos mosquitos ou por OVA.

\section{A}

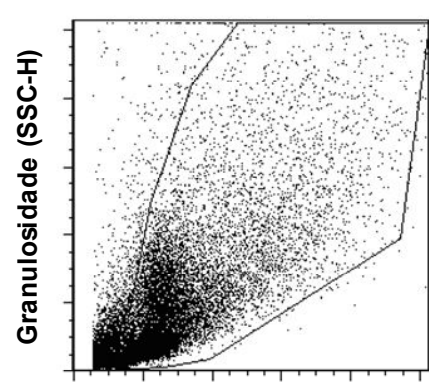

Tamanho (FSC-H)
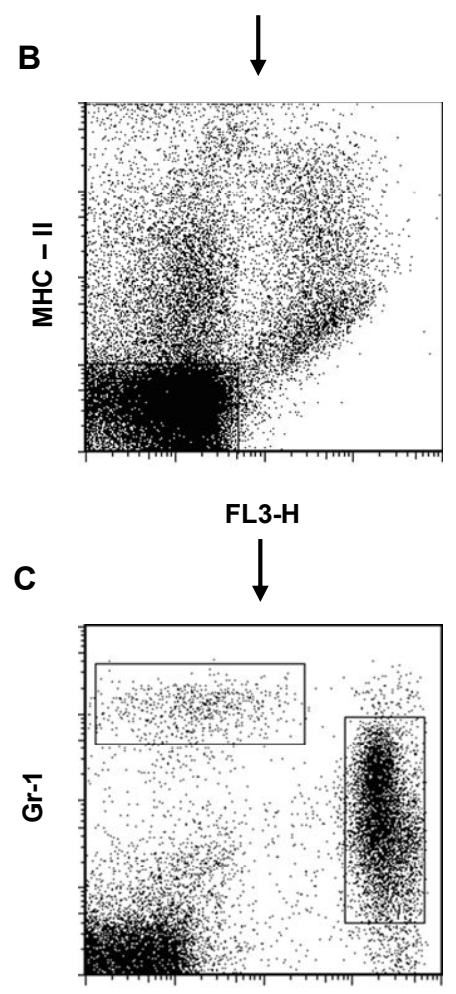

Siglec-F

(A) Exclusão das células mortas e debris celulares; (B) Exclusão de células MHC II positivas e dos eventos autofluorescentes em um canal do citômetro que não possui fluorocromo para ser detectado (nesse caso, FL3-H); (C) Avaliação da expressão das moléculas Siglec-F e Gr-1. 
Figura 3 - Estratégia de análise para avaliar a presença de células linfoides no LBA e no parênquima pulmonar de camundongos sensibilizados ou não pela exposição aos mosquitos ou por OVA.

A

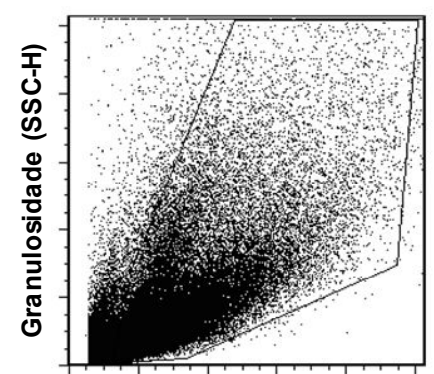

Tamanho (FSC-H)
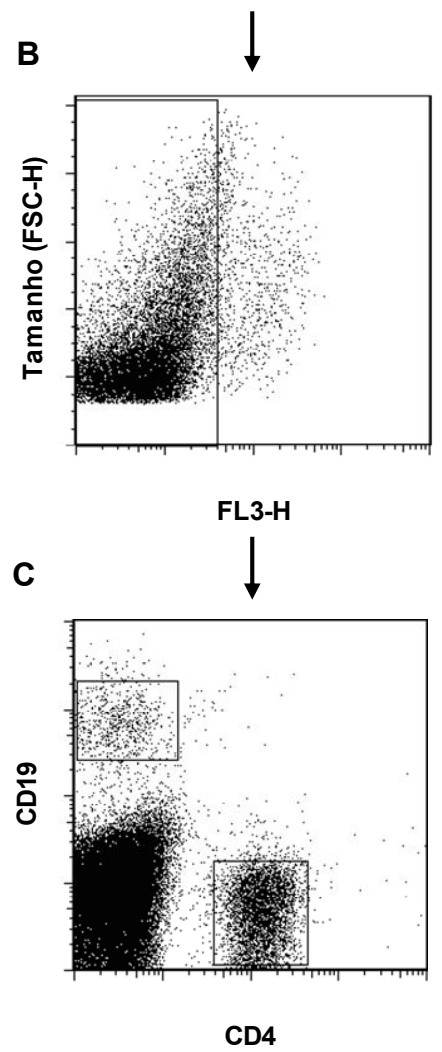

(A) Exclusão das células mortas e debris celulares; (B) Exclusão dos eventos autofluorescentes em um canal do citômetro que não possui fluorocromo para ser detectado (nesse caso, FL3-H); (C) Avaliação da expressão das moléculas CD4 e CD19. 


\subsubsection{Marcadores intracelulares em células de pulmão}

O tecido pulmonar coletado foi primeiramente digerido conforme descrito no item 3.8. Após a digestão, as hemácias foram lisadas e as amostras filtradas. Para marcação intracelular, $3 \times 10^{6}$ células foram incubadas a $37^{\circ} \mathrm{C}$ e $5 \% \mathrm{CO}_{2}$ por 2 horas com PMA (Sigma, $10 \mathrm{ng} / \mathrm{mL}$ ) e ionomicina (Sigma, $500 \mathrm{ng} / \mathrm{mL}$ ). Após a adição de Stop Golgi (Protein Transport Inhibitor, BD Biosciences), as células foram incubadas por mais 3 horas. Após esse período, foi feita, inicialmente, a marcação extracelular. Para isso, as células foram incubadas com a seguinte mistura de anticorpos: anti-CD16/CD32 (Fc Block), anti-CD3 e anti-CD4 (BD Pharmigen ${ }^{\mathrm{TM}}$ ). Após lavagem, as células foram fixadas com solução de paraformaldeído $1 \% \mathrm{e}$ foi feita a marcação intracelular com diferentes anticorpos: IL4, IL5, IL-17A e IFN- $\gamma$. Após a incubação, as células das amostras foram lavadas, ressuspendidas em tampão de FACS e adquiridas em FACSCanto II (BD Biosciences). As análises foram realizadas com o auxílio do software FlowJo, versão 7.5.5.

Tabela 3 - Anticorpos utilizados na análise dos marcadores intracelulares por citometria de fluxo.

\begin{tabular}{ccc}
\hline Anticorpos extracelulares & Fluorocromo & Diluição \\
\hline anti-mouse CD3 & APC-Cy7 & $1: 200$ \\
anti-mouse CD4 & PercP-Cy5.5 & $1: 200$ \\
\hline Anticorpos intracelulares & Fluorocromo & Diluição \\
\hline anti-mouse IL-4 & Pacific Blue & $1: 100$ \\
anti-mouse IL-5 & APC & $1: 100$ \\
anti-mouse IL-17A & PE & $1: 100$ \\
anti-mouse IFN- $\gamma$ & PE-Cy7 & $1: 100$ \\
\hline
\end{tabular}

\subsubsection{Estratégia para análise dos marcadores intracelulares}

Para análise das células T CD4 ${ }^{+}$produtoras das citocinas IL-4, IL-5, IL-17A e IFN- $\gamma$ presentes no parênquima pulmonar, foi feita, primeiramente, a exclusão de células potencialmente mortas e debris celulares. Eventos adquiridos no citômetro com tamanho e granulosidade característicos de células $\mathrm{T}$ foram selecionados através de uma "gate", sendo caracterizados como linfócitos (Figura 4A). Em seguida, estas células foram analisadas em função da expressão das moléculas CD3 e CD4 em sua superfície e os eventos que 
apresentavam fluorescência positiva para esses dois canais foram então selecionados (Figura 4B) e analisadas em função da expressão intracelular de IFN- $\gamma$ e IL-4 (Figura 4C) e IL-17A e IL-5 (Figuras 4D).

Figura 4 - Estratégia de análise para avaliar a produção de citocinas IL-4, IL-5, IL-17A e IFN- $\gamma$ pela população de células T CD4 ${ }^{+}$.

A

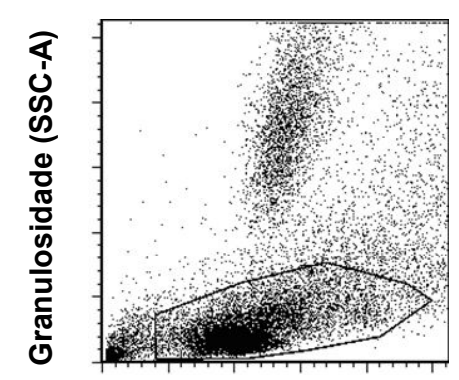

Tamanho (FSC-A)

B

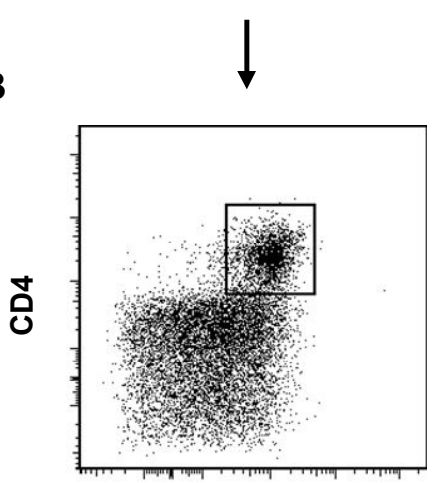

CD3

C

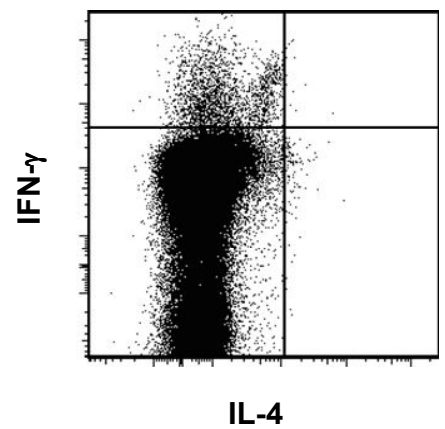

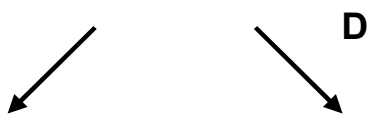

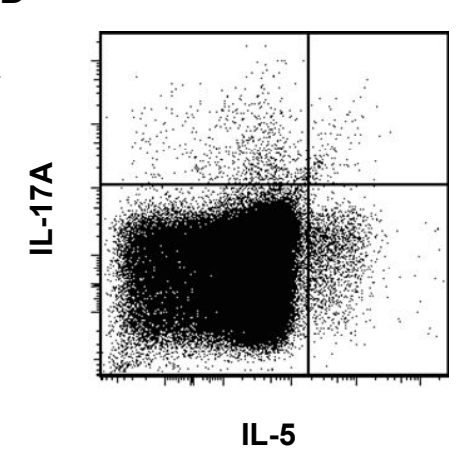

(A) Seleção de linfócitos; (B) Avaliação da expressão das moléculas CD3 e CD4. A partir da população de células $\mathrm{T} \mathrm{CD} 3^{+} \mathrm{CD}^{+}$foi feita uma "gate" de identificação para avaliar a expressão dos marcadores de citocinas IFN- $\gamma$ e IL-4 (C) e IL-17A e IL-5 (D). 


\subsection{ELISA para determinação de citocinas}

Para a dosagem das citocinas IL-4, IL-5, IL-10 e IFN- $\gamma$ presentes no LBA foram utilizados "BD OptEIA ELISA Set" (BD Bioscience Pharmingen, San Diego, CA, USA), seguindo as instruções do fabricante. Resumidamente, placas de 96 poços foram incubadas com anticorpo de captura diluído em tampão carbonato de sódio 0,1 M, pH 9,5 (IL-4, IL-5 e IFN- $\gamma$ ) ou em tampão fosfato de sódio 0,2 M, pH 6,5 (IL-10) (100 $\mu \mathrm{L} /$ poço). Após incubação overnight a $4{ }^{\circ} \mathrm{C}$, as placas foram lavadas 3 vezes com PBS/Tween $0,05 \%$ (300 $\mu \mathrm{L} /$ poço) e, em seguida, bloqueadas com $200 \mu \mathrm{L} /$ poço de PBS/SFB 10\% por $1 \mathrm{~h}$ à temperatura ambiente. Após nova lavagem, as amostras do LBA apropriadamente diluídas e a curva padrão de cada citocina foram adicionadas $(100 \mu \mathrm{L} /$ poço) e incubadas por 2 horas à temperatura ambiente. Após ciclo de 5 lavagens, foi adicionado $100 \mu \mathrm{L}$ /poço de solução de detecção (anticorpo secundário biotinilado e estreptoavidina conjugada com peroxidase) diluída em PBS/SFB $10 \%$ e a placa foi incubada à temperatura ambiente por $1 \mathrm{~h}$. Após 7 lavagens, foram adicionados $100 \mu \mathrm{L}$ /poço da solução substrato 3,3', 5,5' tetramethylbenzidine (TMB) seguida por incubação por no máximo 30 minutos à temperatura ambiente no escuro. Para parar a reação foram adicionados $50 \mu \mathrm{L}$ poço de ácido fosfórico $\left(\mathrm{H}_{3} \mathrm{PO}_{4}\right) 1 \mathrm{M}$ e a leitura da placa foi feita em um espectrofotômetro a $450 \mathrm{~nm}$. A concentração das citocinas presente nas amostras foi calculada com base na curva padrão de cada citocina.

Para a dosagem da citocina IL-13 presente no LBA foi utilizado o "DuoSet Mouse IL13” (R\&D Systems, Minneapolis, MN, USA), seguindo as instruções do fabricante. Para isso, placas de 96 poços foram incubadas com anticorpo anti-IL-13 de camundongo diluído em PBS (100 $\mu \mathrm{L} /$ poço). Após incubação overnight a temperatura ambiente, foram feitas 3 lavagens com PBS/Tween 0,05\%. (300 $\mu \mathrm{L} /$ poço) e, em seguida, bloqueadas com $300 \mu \mathrm{L} /$ poço de PBS/BSA $1 \%$ por $1 \mathrm{~h}$ à temperatura ambiente. Após nova lavagem, as amostras do LBA apropriadamente diluídas e a curva padrão foram adicionadas (100 uL/poço) e incubadas por 2 horas à temperatura ambiente. Após ciclo de 5 lavagens, foi adicionado $100 \mu \mathrm{L} /$ poço de solução de detecção (anticorpo secundário biotinilado) diluídos em PBS/BSA 1\% e incubado à temperatura ambiente por $2 \mathrm{~h}$. Após 5 lavagens foram adicionados $100 \mu \mathrm{L} /$ poço de estreptoavidina conjugada com peroxidase e incubados por 20 minutos à temperatura ambiente. Após 7 lavagens, foram adicionados $100 \mu \mathrm{L}$ /poço da solução substrato 3,3', 5,5' tetramethylbenzidine $(\mathrm{TMB})$ e incubado por no máximo 30 minutos à temperatura ambiente no escuro. Para parar a reação foram adicionados $50 \mu \mathrm{L} /$ poço de ácido sulfúrico $\left(\mathrm{H}_{2} \mathrm{SO}_{4}\right) 2 \mathrm{~N}$ 
e a leitura da placa foi feita em um espectrofotômetro a $450 \mathrm{~nm}$. A concentração de IL-13 presente nas amostras foi calculada com base na curva padrão dessa citocina.

Para a dosagem da citocina IL-17 presente no LBA foi utilizado o "Mouse IL-17A ELISA Max" (BioLegend, San Diego, CA, USA), seguindo as instruções do fabricante. Para isso, placas de 96 poços foram incubadas com anticorpo anti-IL-17a de camundongo diluído em PBS (100 $\mu \mathrm{L}$ /poço). Após incubação overnight a $4{ }^{\circ} \mathrm{C}$, foram feitas 3 lavagens com PBS/Tween 0,05\%. (300 $\mu \mathrm{L} /$ poço) e, em seguida, os poços foram bloqueados com 200 $\mu \mathrm{L} /$ poço de PBS/SFB $10 \%$ por $1 \mathrm{~h}$ à temperatura ambiente, sob agitação. Após nova lavagem, as amostras do LBA apropriadamente diluídas e a curva padrão foram adicionadas (100 uL/poço) e incubadas por 2 horas à temperatura ambiente, sob agitação. Após ciclo de 3 lavagens, foi adicionado $100 \mu \mathrm{L}$ /poço de solução de detecção (anticorpo secundário biotinilado) diluído em PBS/SFB $10 \%$ e incubado à temperatura ambiente por $1 \mathrm{~h}$, sob agitação. Após 3 lavagens foram adicionados $100 \mu \mathrm{L} /$ poço de estreptoavidina conjugada com peroxidase e incubados por 30 minutos à temperatura ambiente, sob agitação. Após 5 lavagens, foram adicionados $100 \mu \mathrm{L}$ /poço da solução substrato 3,3', 5,5' tetramethylbenzidine (TMB) e incubado por no máximo 30 minutos à temperatura ambiente no escuro. Para parar a reação foram adicionados $100 \mu \mathrm{L} /$ poço de ácido fosfórico $\left(\mathrm{H}_{3} \mathrm{PO}_{4}\right) 1 \mathrm{M}$ e a leitura da placa foi feita em um espectrofotômetro a $450 \mathrm{~nm}$. A concentração de IL-17 presente nas amostras foi calculada com base na curva padrão dessa citocina.

\subsection{ELISA para determinação de anticorpos séricos}

Para a dosagem de anticorpos IgE total presentes no soro de animais sensibilizados ou não pela picada de Ae. aegypti ou com OVA foi utilizado "BD OptEIA ELISA Set" (BD Biosciences), seguindo as instruções do fabricante. Para isso, placas de 96 poços foram incubadas com anticorpo anti-IgE de camundongo diluído em tampão Carbonato de Sódio, $0,1 \mathrm{M}, \mathrm{pH} 9,5\left(100 \mu \mathrm{L} /\right.$ poço). Após incubação overnight a $4{ }^{\circ} \mathrm{C}$, foram feitas 3 lavagens com PBS/Tween 0,05\%. (300 $\mu \mathrm{L} /$ poço) e, em seguida, os poços foram bloqueados com 200 $\mu \mathrm{L} /$ poço de $\mathrm{PBS} / \mathrm{SFB} 10 \%$ por $1 \mathrm{~h}$ à temperatura ambiente. Após nova lavagem, as amostras de soro apropriadamente diluídas e a curva padrão de $\operatorname{IgE}$ foram adicionadas ( $100 \mathrm{uL} /$ poço $)$ e incubadas por 2 horas à temperatura ambiente. Após ciclo de 5 lavagens, foi adicionado 100 $\mu \mathrm{L} /$ poço de solução de detecção (anticorpo secundário biotinilado e estreptoavidina conjugada com peroxidase) diluída em PBS/SFB 10\% e a placa foi incubada à temperatura ambiente por 1 h. Após 7 lavagens, foram adicionados $100 \mu \mathrm{L} /$ poço da solução substrato 3,3', 5,5' 
tetramethylbenzidine (TMB) e incubado por no máximo 30 minutos à temperatura ambiente no escuro. Para parar a reação foram adicionados $50 \mu \mathrm{L}$ /poço de ácido fosfórico $\left(\mathrm{H}_{3} \mathrm{PO}_{4}\right) 1 \mathrm{M}$ e a leitura da placa foi feita em um espectrofotômetro a $450 \mathrm{~nm}$. A concentração de $\operatorname{IgE}$ presente nas amostras de soro foi calculada com base na curva padrão desse anticorpo.

Para a dosagem de anticorpos IgG1 e IgG2a específicos para componentes salivares do mosquito e para OVA, padronizamos no laboratório um ELISA para essa finalidade. Alíquotas de $100 \mu \mathrm{L}$ de EGS (5 $\mu \mathrm{g} / \mathrm{mL})$ preparadas em tampão carbonato de sódio $0,1 \mathrm{M}, \mathrm{pH}$ 9,5, foram adicionadas em placas de 96 poços. Para a quantificação de IgG1 e IgG2a OVAespecíficos, as placas foram sensibilizadas com $100 \mu \mathrm{L}$ de OVA $(20 \mu \mathrm{g} / \mathrm{mL})$. Anticorpos antiIgG1 e anti-IgG2a de camundongo foram adicionados nos poços correspondentes as curvapadrão para cada isótipo. Em seguida, as placas foram incubadas overnight a $4{ }^{\circ} \mathrm{C}$. No dia seguinte, a placa foi lavada 3 vezes com PBS/Tween $0,05 \%$ e os poços foram bloqueados com $200 \mu \mathrm{L} /$ poço de PBS/SFB $10 \%$ por $1 \mathrm{~h}$ à temperatura ambiente. Após nova lavagem, as amostras de soro apropriadamente diluídas e a curva padrão de $\operatorname{IgG} 1$ e $\operatorname{IgG} 2$ a foram adicionadas (100 uL/poço) e incubadas por 2 horas à temperatura ambiente. Após ciclo de 5 lavagens, foi adicionado $100 \mu \mathrm{L}$ /poço de solução de detecção (anticorpo secundário conjugado com peroxidase) anti-IgG1 (BD Biosciences) ou anti-IgG2a (Invitrogen) diluídos em PBS/SFB $10 \%$ e a placa foi incubada à temperatura ambiente por 1 h. Após 7 lavagens, foram então adicionados $100 \mu \mathrm{L}$ /poço da solução substrato 3,3', 5,5' tetramethylbenzidine (TMB) e incubado por no máximo 30 minutos a temperatura ambiente no escuro. Para parar a reação, foram adicionados $50 \mu \mathrm{L}$ /poço de ácido fosfórico $\left(\mathrm{H}_{3} \mathrm{PO}_{4}\right) 1 \mathrm{M}$ e a leitura da placa foi feita em um espectrofotômetro a $450 \mathrm{~nm}$. A concentração de cada anticorpo presente nas amostras de soro foi calculada com base na curva padrão desse anticorpo.

\subsection{Exame histológico dos pulmões e quantificação de muco e colágeno}

Após a coleta do LBA, os pulmões foram perfundidos via ventrículo direito do coração com $10 \mathrm{~mL}$ de PBS gelado para remoção de sangue residual. Em seguida, o lobo superior do pulmão esquerdo de cada animal foi coletado e fixado por imersão em formalina tamponada $10 \%$ por $24 \mathrm{~h}$. Após esse período, os órgãos foram mantidos em etanol $70 \%$ até serem incluídos em parafina. Cortes de $5 \mu \mathrm{m}$ foram produzidos e as lâminas foram coradas com: 1) Hematoxilina/Eosina (H\&E), para visualização do infiltrado celular presente no pulmão; 2) PAS (“Periodic Acid-Schiff”), para evidenciar o muco produzido pelas células do epitélio brônquico; 3) coloração por Tricrômio de Masson, para quantificação do colágeno. 
Utilizando morfometria computadorizada, o muco corado pelo PAS e o colágeno corado pelo Masson, foram quantificados. As imagens foram analisadas com aumento de 10x ou 20x. O índice de muco e colágeno foi calculado como porcentagem da área do brônquio marcada pelo PAS e coloração de Tricrômio de Masson, respectivamente.

\subsection{Quantificação do repasto sanguíneo}

Os mosquitos utilizados no protocolo de sensibilização às picadas e cujo repasto foi confirmado visualmente (volume e coloração do abdômen) foram congelados após o procedimento. Posteriormente, cada mosquito foi macerado em um tubo eppendorf contendo $200 \mu \mathrm{L}$ de água destilada, com o auxílio de um pistilo. O homogeneizado de cada mosquito foi transferido para um poço individual de uma placa de 96 poços de fundo em "U" que foi centrifugada por 10 minutos a $300 \mathrm{~g}$ para sedimentação do material particulado. Após a centrifugação, $100 \mu \mathrm{L}$ do sobrenadante livre de debris celulares foram então transferidos para outra placa de 96 poços de fundo plano e a densidade óptica das amostras determinada em um espectrofotômetro a $540 \mathrm{~nm}$ para avaliação indireta da hemoglobina presente.

\subsection{Análise estatística}

Todos os dados estão apresentados como média \pm erro padrão da média. A análise estatística dos resultados foi feita utilizando-se a análise de variância (ANOVA) usando Tukey como pós-teste, com significância estatística mínima estabelecida em $p \leq 0,05$. 
4 RESULTADOS 


\subsection{Exposição de camundongos BALB/c a picadas de mosquitos Ae. aegypti seguida por desafio intranasal com EGS induz inflamação pulmonar.}

Avaliamos inicialmente o perfil da resposta imunológica sistêmica desenvolvida por camundongos BALB/c expostos a picadas de mosquitos Ae. aegypti. Para tanto, desenvolvemos um protocolo de alta infestação (Figura 1) que consiste na sensibilização natural pela picada de aproximadamente 50 mosquitos Ae. aegypti fêmeas realizada 1 ou 4 vezes consecutivas em intervalos de 14 dias entre as exposições (dias 0, 14, 28 e 42), seguido pelo desafio i.n. com EGS de Ae. aegypti nos dias 49 e 56. Animais controles não sensibilizados receberam apenas desafio i.n. com PBS ou EGS nos dias 49 e 56.

Para análise do perfil inflamatório pulmonar decorrente do desafio, os animais foram eutanasiados 24 h após o segundo desafio com PBS ou EGS e o LBA foi coletado para contagem total e diferencial das células. Em nossas condições experimentais, o desafio intranasal com EGS não induziu recrutamento celular para o espaço broncoalveolar de animais controles (não sensibilizados) quando comparado ao grupo que recebeu PBS no desafio. Por outro lado, camundongos expostos às picadas dos mosquitos e desafiados com EGS de Ae. aegypti apresentaram uma resposta inflamatória robusta com aumento do número de células totais no LBA (Figura 5A). Essa diferença foi estatisticamente significativa tanto no grupo que foi exposto apenas uma vez (grupo "1x") quanto no grupo que foi exposto quatro vezes (grupo "4x") aos mosquitos (Figura 5A - $p<0,05$ versus grupo "PBS"). Além disso, a comparação feita entre os dois grupos sensibilizados mostrou que o infiltrado inflamatório foi significativamente maior no grupo " $4 \mathrm{x}$ ” quando comparado ao grupo " $1 \mathrm{x}$ ” $(p<0,05)$.

Para caracterizar o tipo celular predominante no infiltrado inflamatório, foi realizada também a contagem diferencial das células recuperadas do LBA em lâminas preparadas em citocentrífuga. Observamos aumento significativo de células mononucleares presentes no LBA de animais de ambos os grupos sensibilizados ("1x" e "4x") em relação aos grupos "PBS" e "EGS" ( $p<0,05$ - Figura 5B). Também foi observado aumento significativo de neutrófilos no grupo "4x" quando comparado aos grupos "PBS" e "EGS" $(p<0,05)$, embora a contagem dessas células tenha sido muito baixa em todos os grupos se comparada aos outros tipos celulares presentes no LBA (Figura 5C). Por outro lado, pode-se observar que houve aumento significativo de eosinófilos nos grupos sensibilizados quando comparados com os grupos "PBS" e "EGS" ( $p<0,05$ - Figura 5D). Em todos os casos, o número de células mononucleares, neutrófilos e eosinófilos presentes no LBA do grupo " $4 \mathrm{x}$ " apresentaram-se significativamente maiores do que no grupo " $1 \mathrm{x}$ ” $(p<0,05)$. 
Esses resultados mostram que o influxo de células induzido pelo EGS para o espaço broncoalveolar de camundongos aumenta de forma proporcional ao número de infestações realizadas. Além disso, as células mononucleares e os eosinófilos foram os tipos celulares majoritários na composição do infiltrado inflamatório observado no LBA de camundongos sensibilizados e desafiados com EGS. A presença destas células é evidente quando observadas as imagens das lâminas preparadas com o material do LBA proveniente dos animais dos grupos "1x" e "4x" (Figuras 5G e 5H, respectivamente), em relação aos animais dos grupos "PBS" (Figura 5E) e "EGS" (Figura 5F).

Com o objetivo de refinar a fenotipagem das células presentes no LBA, avaliamos a seguir alguns marcadores de superfície dessas células por citometria de fluxo, cujos números absolutos são apresentados na Figura 6. Corroborando os dados de microscopia óptica, a citometria de fluxo confirmou que houve um aumento significativo na população Siglec- $\mathrm{F}^{+} / \mathrm{Gr}-$ $1^{\mathrm{INT}}$ (eosinófilos) presentes no LBA de animais sensibilizados quando comparado ao grupo controle $(p<0,05)$. Esse aumento aconteceu de maneira dependente do número de exposições aos mosquitos, mas nesse tipo de análise, foi estatisticamente diferente apenas no grupo " $4 \mathrm{x}$ " em relação ao grupo controle (Figura 6A). Não foram observadas diferenças significativas no número total de células Siglec- $\mathrm{F}^{-} / \mathrm{Gr}-1^{\mathrm{HI}}$ (neutrófilos) entre os grupos experimentais (Figura 6B). Dentre as células mononucleares, foi observado um aumento no número absoluto de células $\mathrm{CD}^{+}$(linfócitos T) que também foi dependente da intensidade de exposição aos mosquitos e estatisticamente diferente apenas no grupo " $4 \mathrm{x}$ ” em relação aos grupos PBS e EGS $(p<0,05)$ (Figura 6C). Resultados semelhantes a estes foram observados com relação às células CD19 ${ }^{+}$ (linfócitos B) entre os diferentes grupos (Figura 6D). O número de células $\mathrm{CD}^{+}, \mathrm{CD} 19^{+}$e eosinófilos também se mostrou estatisticamente diferente quando comparados os grupos " $4 \mathrm{x}$ " e "1x" ( $p<0,05)$. O número de células $\mathrm{CD}^{+}$detectado nas amostras foi negligenciável e não diferiu entre os diferentes grupos experimentais (dados não mostrados).

A presença de eosinófilos, neutrófilos, células $\mathrm{CD}^{+}$e células $\mathrm{CD}_{1} 9^{+}$no parênquima pulmonar de animais expostos aos mosquitos Ae. aegypti também foi avaliada por citometria de fluxo e os números absolutos desses tipos celulares estão apresentados na Figura 7. Assim como observado no LBA, o pulmão de animais sensibilizados também apresentou aumento na população de eosinófilos, com diferença significativa entre o grupo " $4 \mathrm{x}$ " e todos os outros grupos $(p<0,05$ - Figura 7A). Neutrófilos também foram detectados no pulmão por citometria de fluxo, embora em números bastante reduzidos quando comparados com outros tipos celulares. $\mathrm{O}$ número basal dessas células se mostrou estatisticamente reduzido em todos os grupos experimentais quando comparados com o grupo controle (Figura 7B). No entanto, vale ressaltar 
que a diferença observada entre os grupos foi mínima e só foi estatisticamente significativa por conta da pequena variação entre os animais do mesmo grupo. Ao contrário do que foi observado no LBA, não houve aumento do número de células $\mathrm{CD} 4^{+}$no pulmão dos grupos experimentais (Figura 7C). O número de células $\mathrm{CD}^{+}$se manteve constante ao longo do protocolo de sensibilização, não sendo possível observar diferenças nos valores dos grupos sensibilizados em relação aos demais grupos. O número de linfócitos B (células CD19 ${ }^{\dagger}$ ) apresentou-se reduzido no pulmão de animais sensibilizados dos grupos "EGS", "1x" e " $4 \mathrm{x}$ ” em relação ao controle, mas novamente essa diferença foi mínima e só ocorreu devido à pequena variação entre as amostras (Figura 7D). 
Figura 5 - Infiltrado inflamatório no LBA de camundongos expostos ou não às picadas de Ae. aegypti e desafiados com PBS ou EGS.

A

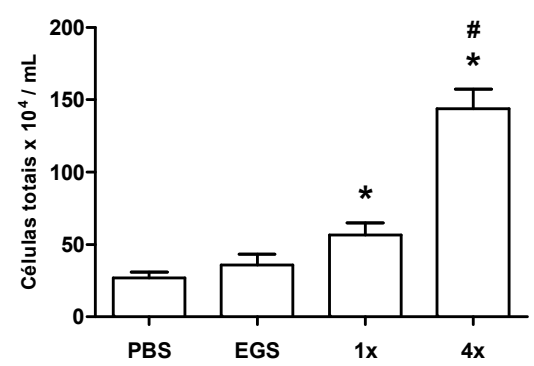

C

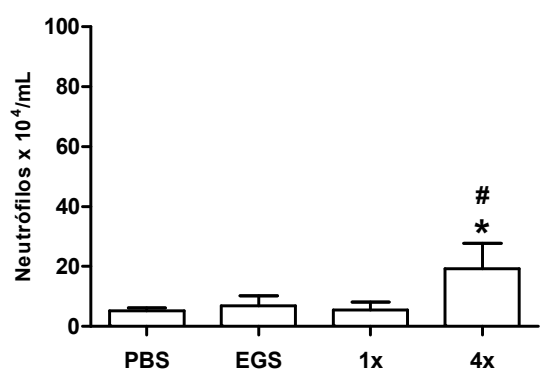

E

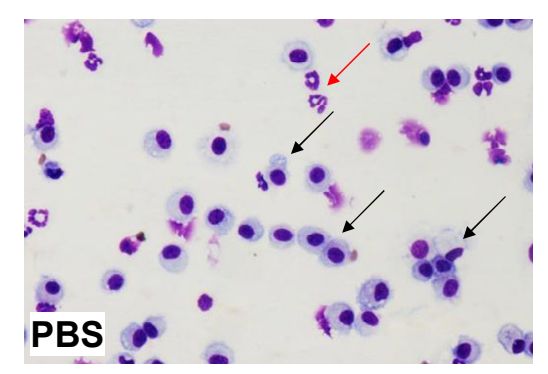

G

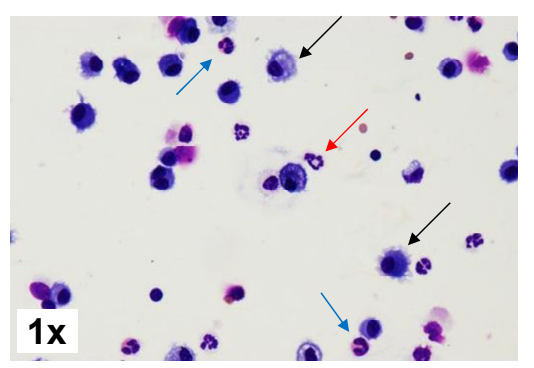

B

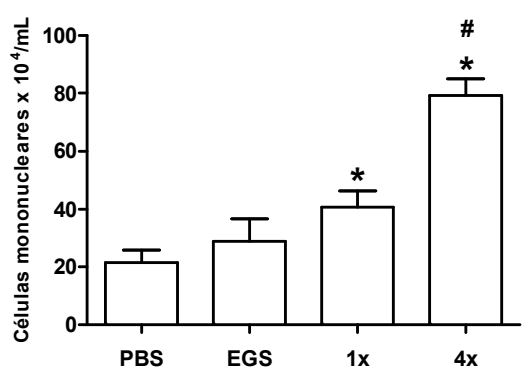

D

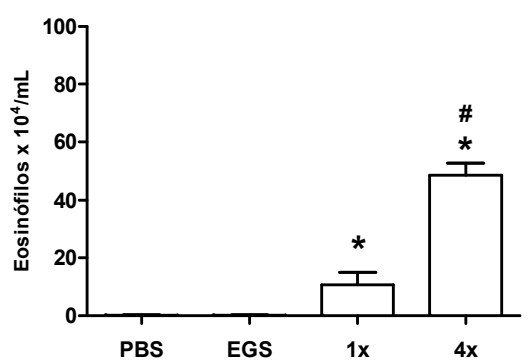

$\mathbf{F}$

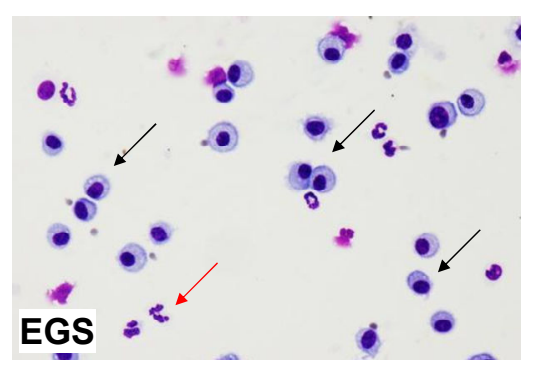

$\mathbf{H}$

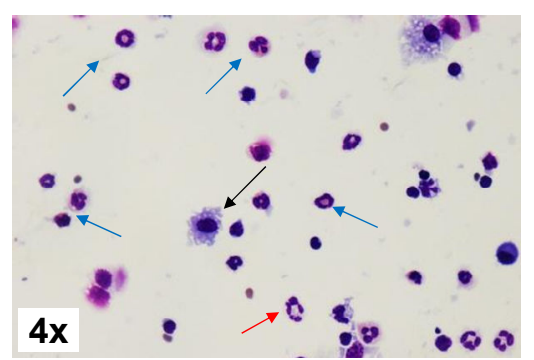

A coleta do LBA foi realizada $24 \mathrm{~h}$ após o segundo desafio i.n. com PBS ou EGS e o número de células totais e diferenciais foi determinado conforme descrito em Material e Métodos. (A) Células totais, (B) células mononucleares, (C) neutrófilos, (D) eosinófilos, fotomicrografias das células do LBA coradas com corante hematológico para caracterização morfológica das células inflamatórias dos grupos (E) "PBS" e (F) "4x". Setas pretas indicam células mononucleares, setas vermelhas indicam neutrófilos e setas azuis indicam eosinófilos. Resultados expressos como média $\pm \mathrm{SEM}(\mathrm{n}=5)$. ${ }^{*} p<$ 0,05 versus grupo "PBS", $p<0,05$ versus grupo "EGS", ${ }^{\star} p<0,05$ versus grupo "1x". 
Figura 6 - Efeito da exposição e desafio com componentes salivares de Ae. aegypti no acúmulo de eosinófilos, neutrófilos, células $\mathrm{CD}^{+}{ }^{+}$e $\mathrm{CD} 19^{+}$no LBA de camundongos $\mathrm{BALB} / \mathrm{c}$.

A

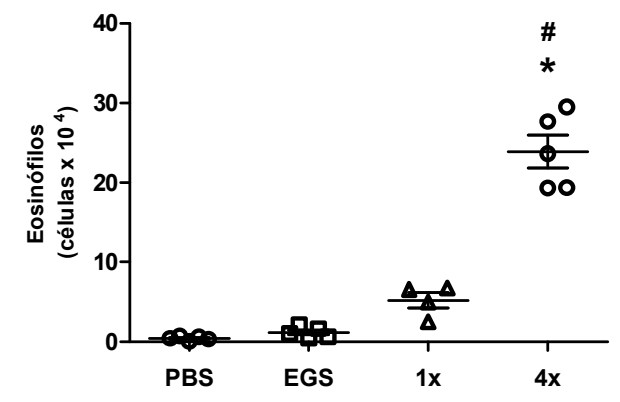

C

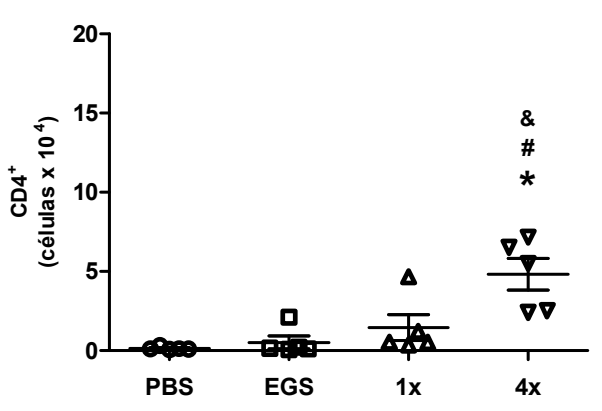

B

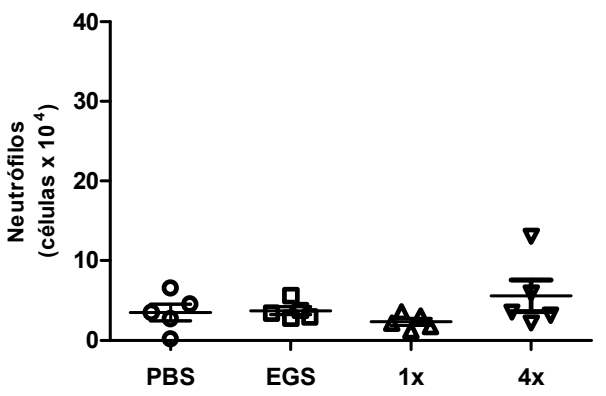

D

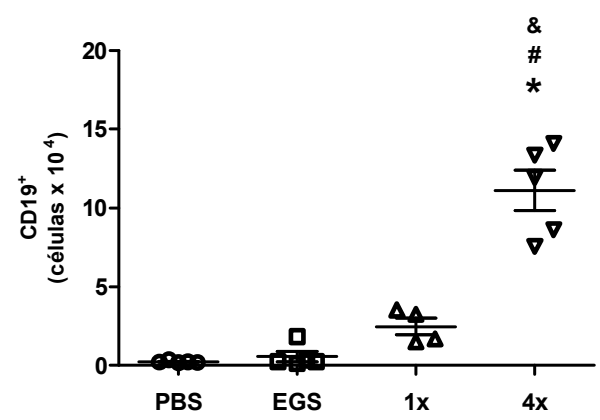

Células do LBA de animais sensibilizados ou não foram coletadas $24 \mathrm{~h}$ após o segundo desafio i.n. com PBS ou EGS. As células foram marcadas com anticorpos anti-MHC II, anti-Gr1, anti-Siglec-F, anti-CD4 e anti-CD19 e, em seguida, analisadas por citometria de fluxo como descrito em Material e Métodos. O número de eosinófilos (A), neutrófilos (B), células $\mathrm{CD}^{+}(\mathrm{C})$ e $\mathrm{CD} 19^{+}$(D) foi obtido através da multiplicação do número total de células no LBA pela porcentagem de células com os marcadores MHC II $/$ Siglec $^{-} \mathrm{F}^{+} / \mathrm{Gr}^{\mathrm{INT}}, \mathrm{MHC}^{-} /$Siglec-F $/ \mathrm{Gr}^{\mathrm{HI}}, \mathrm{MHC}^{-} \mathrm{II}^{+} / \mathrm{CD}^{+} / \mathrm{CD}^{-} 9^{-}$e $\mathrm{MHC}^{-} \mathrm{II}^{+} / \mathrm{CD}^{-}$ $/ \mathrm{CD} 19^{+}$, respectivamente. Resultados expressos como média $\pm \operatorname{SEM}(\mathrm{n}=5) .{ }^{*} p<0,05$ versus grupo "PBS", $p<0,05$ versus grupo "EGS”, " $p<0,05$ versus grupo " $1 \mathrm{x}$ ". 
Figura 7 - Efeito da exposição e desafio com componentes salivares de Ae. aegypti no acúmulo de eosinófilos, neutrófilos, células $\mathrm{CD}^{+}$e $\mathrm{CD} 19^{+}$no parênquima pulmonar de camundongos BALB/c.

A

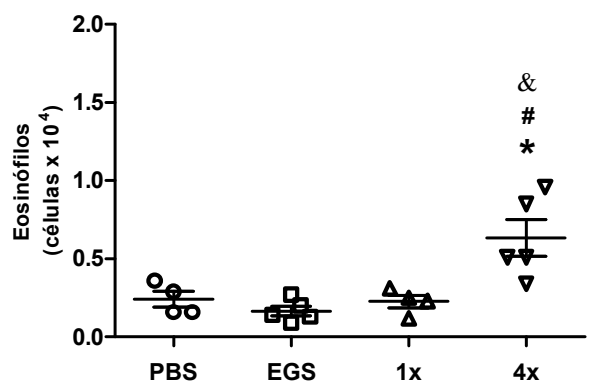

C

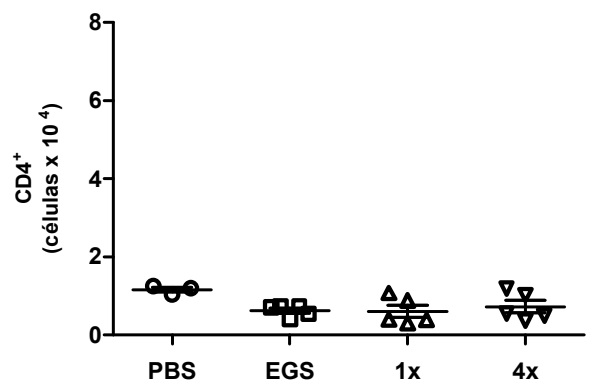

B

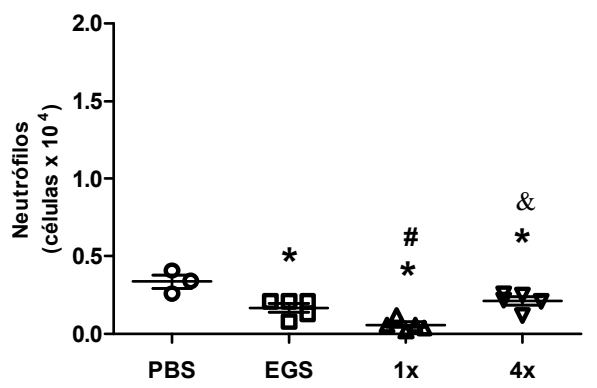

D

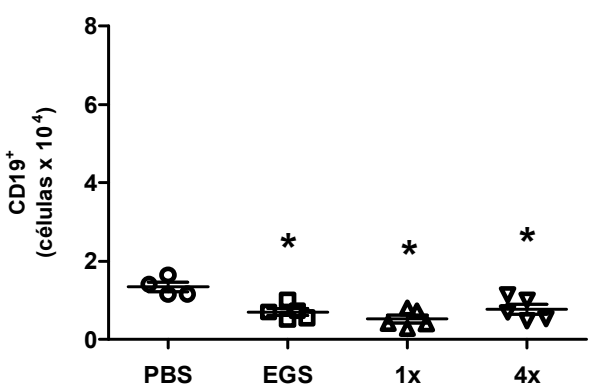

Células do parênquima pulmonar de animais sensibilizados ou não foram coletadas $24 \mathrm{~h}$ após o segundo desafio i.n. com PBS ou EGS. As células foram marcadas com anticorpos anti-MHC II, antiGr1, anti-Siglec-F, anti-CD4 e anti-CD19 e, em seguida, analisadas por citometria de fluxo. As células foram separadas em uma janela MHC II e FL3-H negativas para análise de eosinófilos e neutrófilos ou somente FL3-H negativas para análise de células $\mathrm{CD}^{+}$e $\mathrm{CD} 19^{+}$. O número de eosinófilos (A), neutrófilos (B), células $\mathrm{CD}^{+}(\mathrm{C})$ e $\mathrm{CD} 19^{+}$(D) foi obtido através da multiplicação do número total dessas células no pulmão pela porcentagem de células com os marcadores $\mathrm{MHC} \mathrm{II}^{-} / \mathrm{Siglec}^{-} \mathrm{F}^{+} / \mathrm{Gr}^{\mathrm{INT}}$, MHC $\mathrm{II}^{-} /$Siglec-F$/ \mathrm{Gr}^{-\mathrm{HI}}$, $\mathrm{MHC}^{-} \mathrm{II}^{+} / \mathrm{CD}^{+} / \mathrm{CD}^{-} 9^{-}$e $\mathrm{MHC}^{-} \mathrm{II}^{+} / \mathrm{CD}^{-} / \mathrm{CD}^{2} 9^{+}$, respectivamente. Resultados expressos como média \pm SEM $(\mathrm{n}=5)$. * $p<0,05$ versus grupo "PBS", ${ }^{*} p<0,05$ versus grupo "EGS", \& $p<0,05$ versus grupo " $1 \mathrm{x}$ ". 


\subsection{Comparação dos efeitos da sensibilização pelas picadas de mosquitos Ae. aegypti com modelo murino de asma induzido por OVA}

\subsubsection{Infiltrado inflamatório}

Como o desafio intranasal com EGS induziu influxo de células para o tecido pulmonar de animais sensibilizados com picadas de Ae aegypti de forma muito semelhante ao observado em outros modelos de reações alérgicas, o passo seguinte foi comparar os parâmetros inflamatórios no modelo induzido pela picada de mosquito ao modelo clássico de inflamação pulmonar induzida por imunização e desafio com OVA. Como os protocolos são diferentes, os mesmos foram sincronizados de forma que os desafios e a coleta de fluídos e tecidos ocorressem nos mesmos dias.

Inicialmente, quantificamos o número total de células presentes no LBA. Nossos resultados mostram que ambos os protocolos de sensibilização induziram um aumento significativo no influxo de células para espaço broncoalveolar quando comparados ao grupo controle ( $p<0,05$ versus "PBS" e "EGS" - Figura 8A). Além disso, também foi observada diferença estatística entre os grupos “4x" e "OVA” $(p<0,05)$.

Com relação à contagem diferencial, observamos aumento discreto das células mononucleares presentes no LBA de animais sensibilizados pelas picadas dos mosquitos, porém, somente no grupo "OVA" essa diferença foi estatisticamente diferente em relação ao grupo "PBS" ( $p<0,05$ - Figura 8B). Já os neutrófilos se mostraram aumentados tanto no grupo "4x" quanto no grupo "OVA" ( $p<0,05$ versus grupo "PBS"). Entretanto, a contagem dessas células foi muito baixa quando comparada aos outros tipos celulares presentes no LBA (Figura 8C). Os animais dos grupos " $4 \mathrm{x}$ " e "OVA" também apresentaram um aumento significativo no número de eosinófilos, quando comparados com o grupo "PBS" ( $p<0,05$ - Figura 8D). Além disso, a comparação do número de eosinófilos entre os grupos " $4 \mathrm{x}$ " e "OVA" também apresentou diferença estatisticamente significativa. A presença desse tipo celular é evidente quando observadas as imagens das lâminas preparadas com o material do LBA proveniente de animais dos grupos " $4 \mathrm{x}$ " e "OVA" (Figuras $8 \mathrm{G}$ e $8 \mathrm{H}$, respectivamente) em relação aos animais dos grupos "PBS" ou "EGS" (Figuras 8E e 8F, respectivamente).

Estes resultados mostram que o aumento do número de células totais presentes no LBA de animais sensibilizados pela picada dos mosquitos Ae. aegypti ou sensibilizados com OVA foi constituído pelo influxo de células mononucleares e eosinófilos, embora também tenha sido observado um pequeno, porém significativo, aumento de neutrófilos. Ainda que o aumento no 
número de células totais observado no grupo "OVA" tenha sido um pouco maior que no grupo " $4 \mathrm{x}$ ", pode-se notar que o perfil de migração dos diferentes tipos celulares foi comparável nos dois protocolos de sensibilização analisados.

As células presentes no LBA também foram analisadas por citometria de fluxo. A Figura 9 mostra que em ambos os protocolos de sensibilização e desafio, o influxo de células para o espaço broncoalveolar foi caracterizado pela presença de eosinófilos, células $\mathrm{CD}^{+} \mathrm{e}$ $\mathrm{CD} 19^{+}$. Pode-se observar que houve aumento significativo na população de eosinófilos, células $\mathrm{CD}^{+}{ }^{+} \mathrm{CD} 19^{+}$presentes no LBA de camundongos sensibilizados tanto pela exposição aos mosquitos Ae. aegypti quanto com "OVA" em relação ao grupo "PBS". Essa diferença também ocorreu para o grupo "4x" em comparação com o grupo "EGS", com exceção das células $\mathrm{CD}^{+} 9^{+}(p<0,05$ - Figuras 9A, 9C e 9D, respectivamente). Ainda, o número desses tipos celulares também foi estatisticamente diferente entre os grupos "OVA" e "4x". Não foi possível observar diferença significativa no número de neutrófilos presentes no LBA dos diferentes grupos estudados (Figura 9B).

A análise por citometria de fluxo mostrou que os pulmões de animais dos grupos " $4 \mathrm{x}$ " $\mathrm{e}$ "OVA" apresentaram aumento significativo na população de eosinófilos e que ambos os grupos foram estatisticamente diferentes do grupo "PBS" com relação a esse tipo celular $(p<0,05$ Figura 10A). No entanto, não houve diferença significativa no número total de eosinófilos quando o grupo OVA foi comparado ao grupo " $4 \mathrm{x}$ ”. Novamente foi observada presença quase virtual de neutrófilos no pulmão, no entanto, o número dessas células nos grupos "EGS", " $4 \mathrm{x}$ ” e "OVA" estava estatisticamente reduzido em relação ao grupo controle (Figura 10B). Ao contrário do que foi observado no LBA, não houve diferença no número de células $\mathrm{CD} 4^{+} \mathrm{e}$ $\mathrm{CD}_{1}{ }^{+}$no parênquima pulmonar dos grupos experimentais, quando comparado com o grupo PBS (Figuras 10C e 10D, respectivamente). 
Figura 8 - Comparação do infiltrado inflamatório no LBA de camundongos expostos às picadas de mosquitos Ae. aegypti ou sensibilizados com OVA s.c.

A

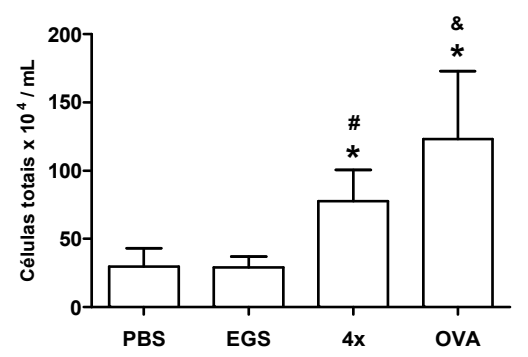

C

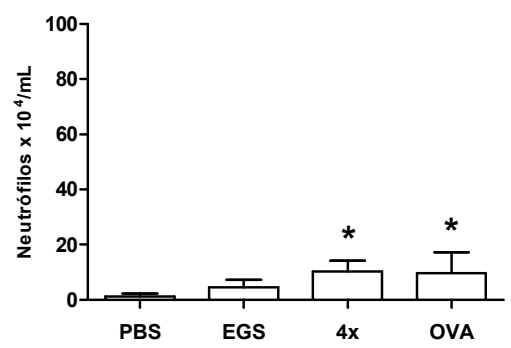

$\mathbf{E}$

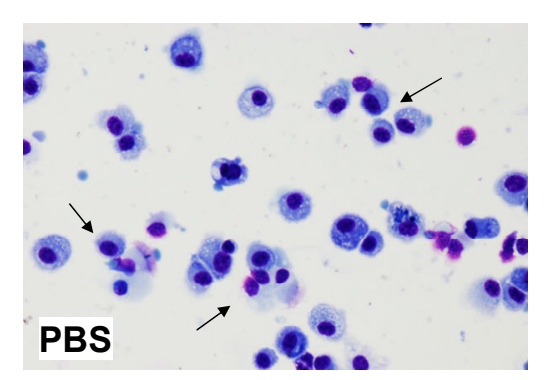

G

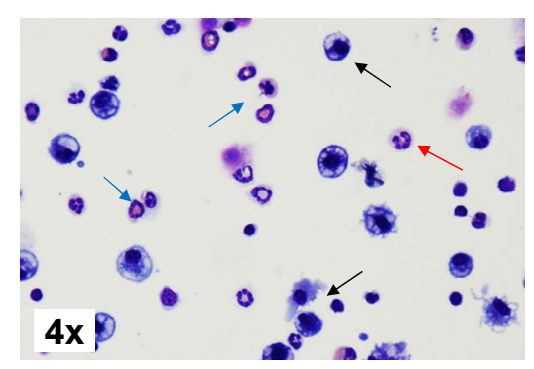

B

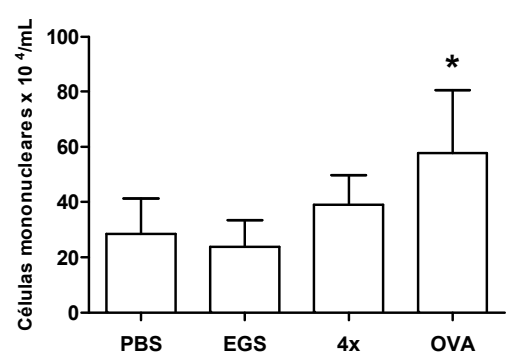

D

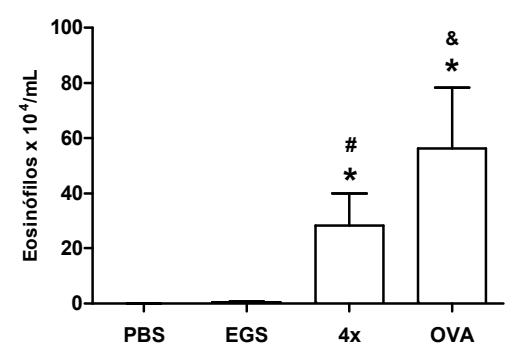

$\mathbf{F}$

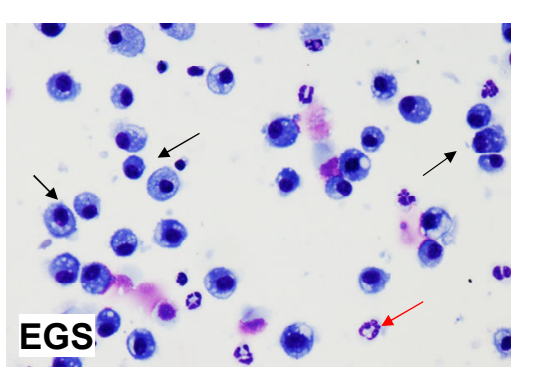

H

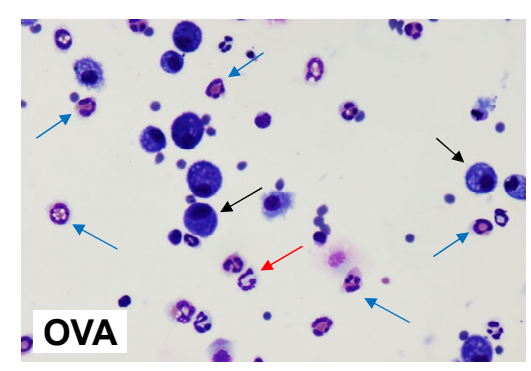

A coleta do LBA foi realizada 24 h após o segundo desafio i.n. com PBS, EGS ou OVA e o número de células totais e diferenciais foi determinado conforme descrito em Material e Métodos. (A) Células totais, (B) células mononucleares, (C) neutrófilos, (D) eosinófilos, fotomicrografias das células do LBA coradas com corante hematológico para caracterização morfológica das células inflamatórias dos grupos (E) PBS, (F) EGS, (G) “4x" e (H) OVA. Setas pretas indicam células mononucleares, setas vermelhas indicam neutrófilos e setas azuis indicam eosinófilos. Resultados expressos como média \pm SEM $(\mathrm{n}=8) .{ }^{*} p<0,05$ versus grupo "PBS", ${ }^{p} p<0,05$ versus grupo "EGS", ${ }^{\&} p<0,05$ versus grupo " $4 \mathrm{x}$ ". 
Figura 9 - Comparação do efeito da exposição e desafio com componentes salivares de $A e$. aegypti ou OVA no acúmulo de eosinófilos, neutrófilos, células $\mathrm{CD} 4^{+}$e CD19 ${ }^{+}$ no LBA de camundongos BALB/c.

A

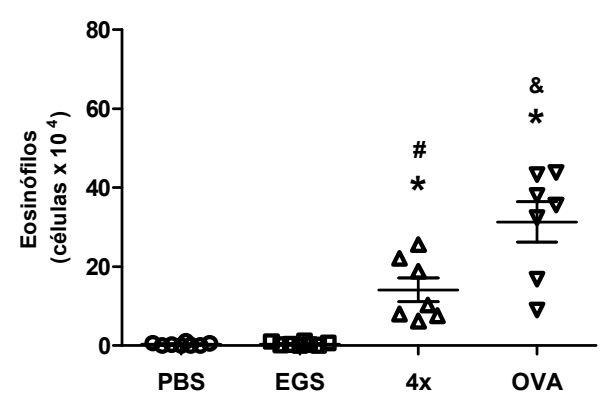

C

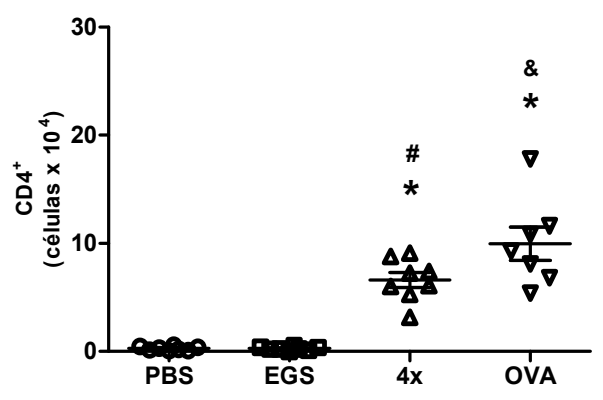

B

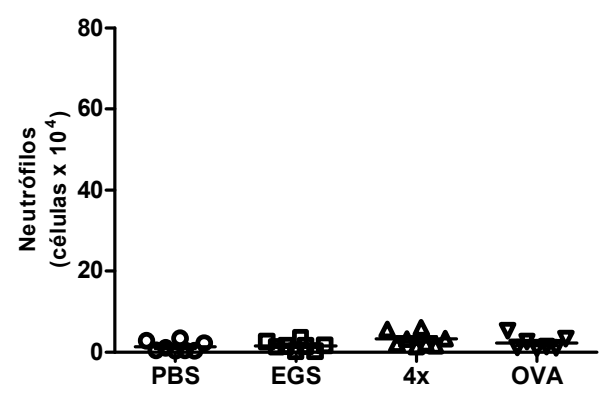

D

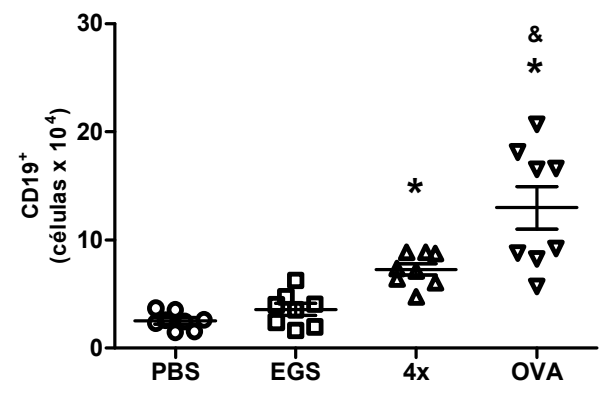

Células do LBA de animais sensibilizados ou não foram coletadas $24 \mathrm{~h}$ após o segundo desafio i.n. com PBS, EGS ou OVA. As células foram marcadas com anticorpos anti-MHC II, anti-Gr1, antiSiglec-F, anti-CD4 e anti-CD19 e, em seguida, analisadas por citometria de fluxo como descrito em Material e Métodos. O número de eosinófilos (A), neutrófilos (B), células $\mathrm{CD}^{+}(\mathrm{C})$ e $\mathrm{CD} 19^{+}$(D) foi obtido através da multiplicação do número total de células no LBA pela porcentagem de células com os marcadores $\mathrm{MHC} \mathrm{II}^{-} / \mathrm{Siglec}^{-} \mathrm{F}^{+} / \mathrm{Gr}^{\mathrm{INT}}$, MHC $\mathrm{II}^{\mathrm{IN}} / \mathrm{Siglec}-\mathrm{F}^{-} / \mathrm{Gr}^{\mathrm{HI}}, \mathrm{MHC}^{-} \mathrm{II}^{+} / \mathrm{CD}^{+} / \mathrm{CD}^{-} 9^{-}$e $\mathrm{MHC}^{-}$ $\mathrm{II}^{+} / \mathrm{CD} 4^{-} / \mathrm{CD} 19^{+}$, respectivamente. Resultados expressos como média $\pm \mathrm{SEM}(\mathrm{n}=8){ }^{*} p<0,05$ versus grupo "PBS", ${ }^{\#} p<0,05$ versus grupo "EGS", ${ }^{~} p<0,05$ versus grupo " $4 \mathrm{x}$ ". 
Figura 10 - Comparação do efeito da exposição e desafio com componentes salivares de $A e$. aegypti ou OVA no acúmulo de eosinófilos, neutrófilos, células $\mathrm{CD} 4^{+}$e CD19 ${ }^{+}$ no parênquima pulmonar de camundongos BALB/c.

A

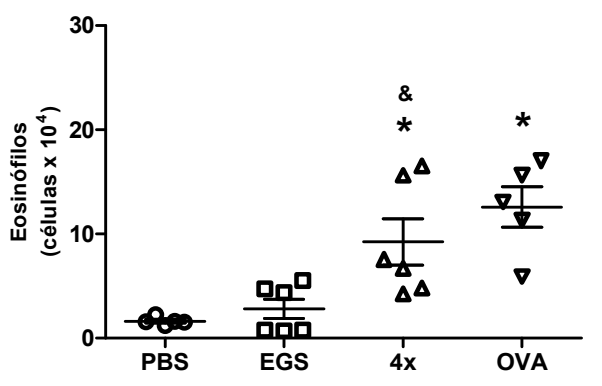

C

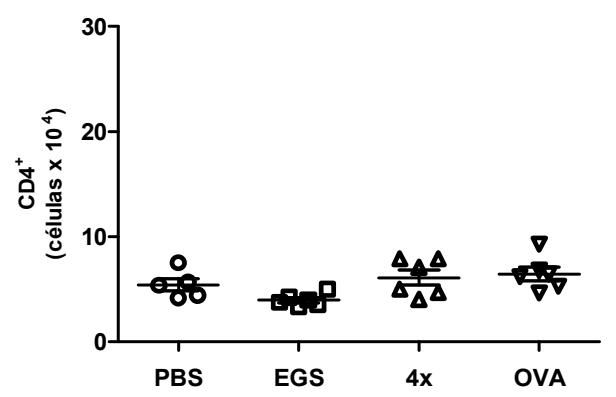

B

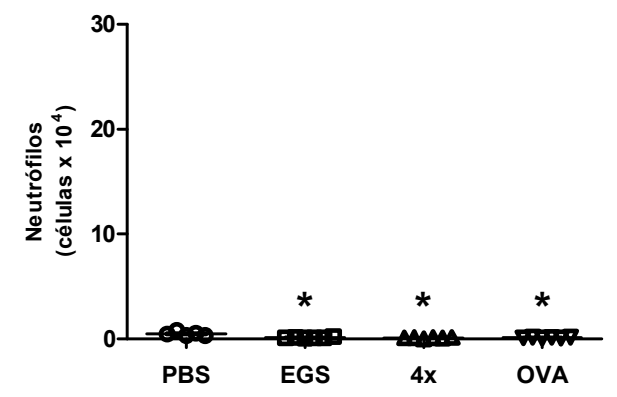

D

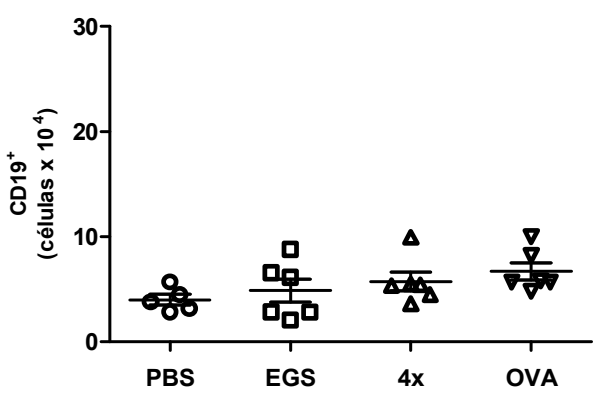

Células do parênquima pulmonar de animais sensibilizados ou não foram coletadas $24 \mathrm{~h}$ após o segundo desafio i.n. com PBS ou EGS. As células foram marcadas com anticorpos anti-MHC II, antiGr1, anti-Siglec-F, anti-CD4 e anti-CD19 e, em seguida, analisadas por citometria de fluxo. As células foram separadas em uma janela MHC II e FL3-H negativas para análise de eosinófilos e neutrófilos ou somente FL3-H negativas para análise de células $\mathrm{CD}^{+}$e $\mathrm{CD}_{1} 9^{+}$. O número de eosinófilos (A), neutrófilos (B), células $\mathrm{CD}^{+}(\mathrm{C})$ e $\mathrm{CD} 19^{+}$(D) foi obtido através da multiplicação do número total de células no pulmão pela porcentagem de células com os marcadores $\mathrm{MHC} \mathrm{II}^{-} / \mathrm{Siglec}^{-} \mathrm{F}^{+} / \mathrm{Gr}^{\mathrm{INT}}, \mathrm{MHC}^{\mathrm{N}}{ }^{-}$ $/$ Siglec-F $/ \mathrm{Gr}^{-\mathrm{HI}}, \mathrm{MHC}^{-} \mathrm{II}^{+} / \mathrm{CD}^{+} / \mathrm{CD} 19^{-}$e $\mathrm{MHC}^{-} \mathrm{II}^{+} / \mathrm{CD} 4^{-} / \mathrm{CD} 19^{+}$, respectivamente. Resultados expressos como média \pm SEM $(\mathrm{n}=8) .{ }^{*} p<0,05$ versus grupo "PBS", ${ }^{p} p<0,05$ versus grupo "EGS", ${ }^{\&}<0,05$ versus grupo " $4 \mathrm{x}$ ". 


\subsubsection{Citocinas}

Além dos marcadores de superfície, também foi feita análise de marcadores intracelulares presentes nas células $\mathrm{T} \mathrm{CD}^{+}$do pulmão desses animais. Os resultados de citometria de fluxo mostram que tanto a sensibilização pelas picadas dos mosquitos quanto a sensibilização com OVA foi capaz de induzir a diferenciação e migração para o pulmão de células T CD4 $4^{+}$produtoras de IL-4. No entanto, apenas no grupo "OVA" o aumento desse tipo celular apresentou diferença estatística em relação ao grupo "PBS" ( $p<0,05$ - Figura 11A). Esse aumento também foi significativo no grupo "OVA" em relação ao grupo " $4 \mathrm{x}$ " ( $p<$ 0,05). Foi possível observar aumento semelhante de células $\mathrm{T} \mathrm{CD}^{+}$produtoras de IL-5 no pulmão dos animais dos grupos " $4 \mathrm{x}$ " e "OVA" em relação ao número de células positivas para esta citocina encontradas nos animais dos grupos controle. Para os dois grupos, o aumento foi estatisticamente diferente em relação ao grupo "PBS" ( $p<0,05$ - Figura 11B). Células T CD4 ${ }^{+}$positivas para as citocinas IL-17 (Figura 11C) e IFN- $\gamma$ (Figura 11D) também foram detectadas na análise por citometria de fluxo, contudo, não foi possível observar diferença significativa no número de células entre os grupos experimentais estudados.

Também determinamos os níveis das citocinas IL-4, IL-5, IL-10, IL-13, IL-17 e IFN- $\gamma$ no sobrenadante do LBA coletados de camundongos sensibilizados e desafiados com componentes salivares de Ae. aegypti e com OVA. Observamos que os animais dos grupos "4x" e "OVA" apresentaram uma significativa produção das citocinas IL-4, IL-5 e IL-13 quando comparados ao grupo "PBS". A produção de IL-4 e IL-13 nos grupos “4x" também foi significativamente maior em comparação ao grupo "EGS" ( $p<0,05$ - Figuras 12A e 12B, respectivamente). Assim como na marcação intracelular, com exceção da IL-4, os níveis das demais citocinas não foram estatisticamente diferentes entre os grupos " $4 \mathrm{x}$ " e "OVA".

Em relação à produção de IL-10 e IFN- $\gamma$, foi observada uma diminuição significativa na quantidade dessas citocinas nos grupos experimentais ("4x" e "OVA") quando comparados com o grupo controle ("PBS"). Ainda, no caso do IFN- $\gamma$, o grupo "EGS" apresentou uma diminuição significativa quando comparado ao grupo "PBS" (Figuras 12C e 12E, respectivamente $-p<0,05$ versus controle). A produção de IL-17 foi semelhante entre todos os grupos estudados (Figura 12D). 
Figura 11 - Análise de células T CD4 $4^{+}$produtoras de IL-4, IL-5, IL-17 e IFN- $\gamma$ presentes no parênquima pulmonar de camundongos $\mathrm{BALB} / \mathrm{c}$ sensibilizados pela exposição aos mosquitos Ae. aegypti ou com OVA.

A

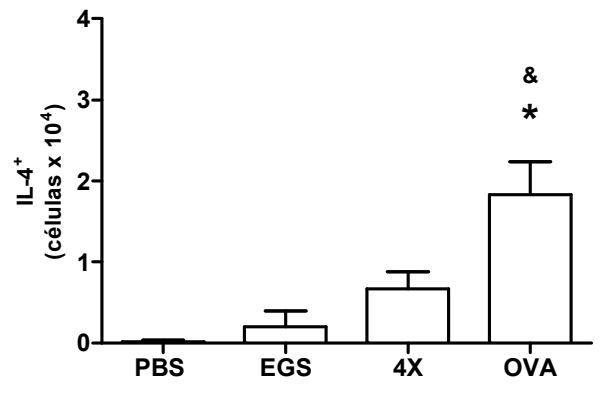

C

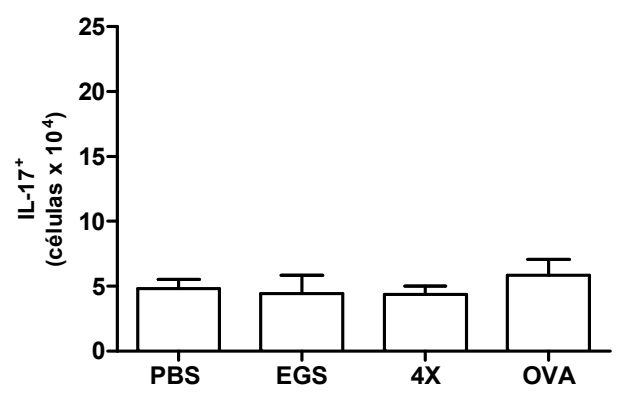

B

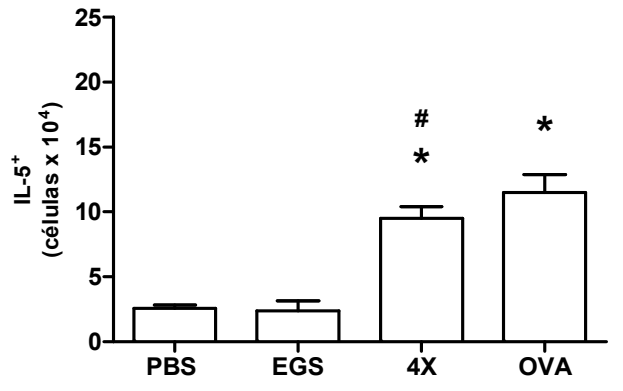

D

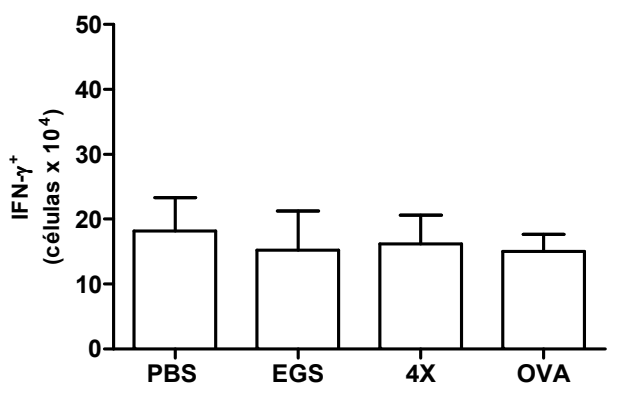

Células do parênquima pulmonar de animais sensibilizados ou não foram coletadas $24 \mathrm{~h}$ após o segundo desafio i.n. com PBS, EGS ou OVA. As células foram marcadas com anticorpos anti-CD3, anti-CD4, anti-IL-4, anti-IL-5, anti-IL-17 e anti-IFN- $\gamma$ e, em seguida, analisadas por citometria de fluxo, conforme descrito em Material e Métodos. O número de células T CD4 ${ }^{+} \mathrm{IL}_{-} 4^{+}(\mathrm{A})$, células $\mathrm{T}$ $\mathrm{CD}^{+} \mathrm{IL}^{-} 5^{+}$(B), células $\mathrm{T} \mathrm{CD} 4^{+} \mathrm{IL}-17^{+}$(C) e células T $\mathrm{CD} 4{ }^{+} \mathrm{IFN}-\gamma^{+}$(D) foi obtido através da multiplicação do número total de células no pulmão pela porcentagem de células positivas para os marcadores IL-4, IL-5, IL-17 e IFN- $\gamma$, respectivamente. Resultados expressos como média \pm SEM $(\mathrm{n}=8) .{ }^{*} p<0,05$ versus grupo "PBS", $p<0,05$ versus grupo "EGS", ${ }^{\&}<0,05$ versus grupo " $4 \mathrm{x}$ ". 
Figura 12 - Concentração de citocinas no LBA de animais expostos às picadas de $A e$. aegypti ou sensibilizados com OVA.

A

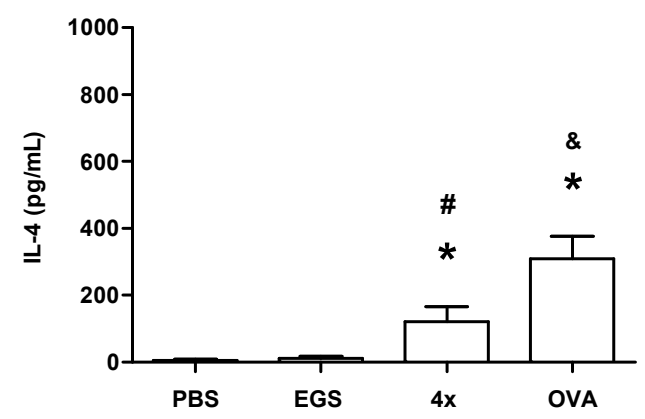

C

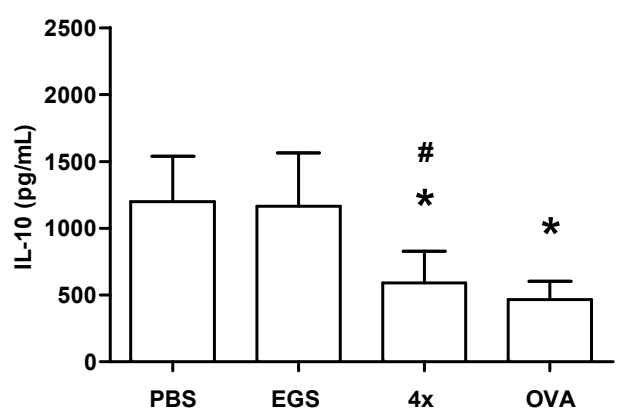

$\mathbf{E}$

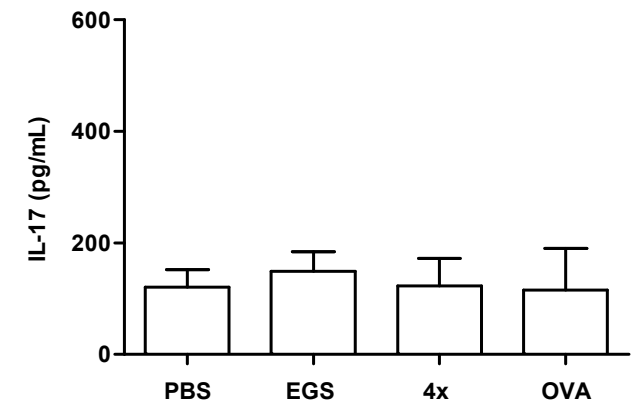

B

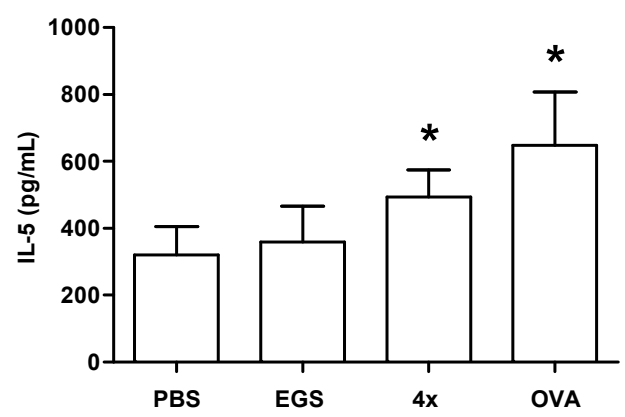

D

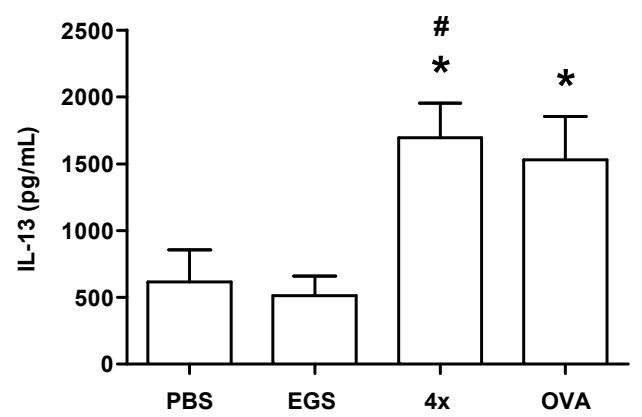

$\mathbf{F}$

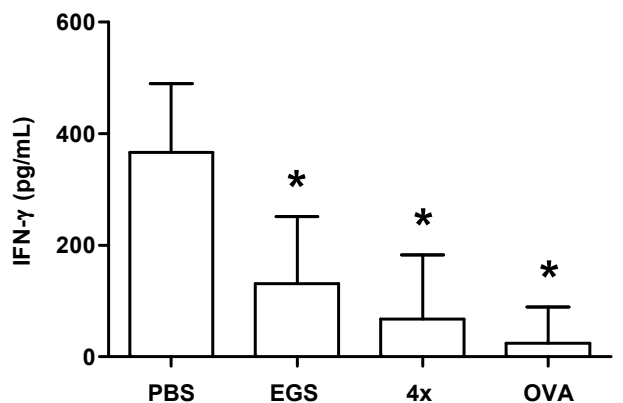

A coleta do LBA foi realizada 24 h após o segundo desafio i.n. com PBS, EGS ou OVA. O LBA foi centrifugado e o sobrenadante utilizado para dosagem da concentração de citocinas conforme descrito em Material e Métodos. IL-4 (A), IL-5 (B), IL-10 (C), IL-13 (D), IL-17 (E) e IFN- $\gamma$ (F). Resultados expressos como média \pm SEM $(\mathrm{n}=8)$. * $p<0,05$ versus grupo "PBS", ${ }^{*} p<0,05$ versus grupo "EGS", ${ }^{\star} p<0,05$ versus grupo " $4 \mathrm{x}$ ”. 


\subsubsection{Isotipos de anticorpos}

O próximo parâmetro comparado entre esses dois modelos foi a produção de anticorpos séricos. Para isso, uma alíquota de sangue foi coletada 24 h após o segundo desafio e o soro foi separado para a determinação da concentração de anticorpos IgE total e IgG1 e IgG2a específicos para componentes salivares do mosquito Ae. aegypti e também para OVA no soro dos animais sensibilizados.

Nossos resultados mostram que animais não sensibilizados apresentam níveis basais de IgE total e níveis virtualmente indetectáveis de IgG1 e IgG2a específicos (Figura 13). A Figura 13A mostra que houve um aumento da concentração de IgE total no soro dos animais expostos tanto aos mosquitos quanto à OVA, quando comparados ao grupo PBS $(p<0,05)$. Também nesse caso, o grupo "OVA" apresentou níveis maiores de IgE do que o grupo " $4 \mathrm{x}$ " ( $p<$ 0,05). O mesmo perfil foi observado na produção de anticorpos IgG1 (Figura 13B). Entretanto, enquanto a presença de anticorpos IgG2a específicos não foi detectada no grupo "OVA", o grupo sensibilizado pelos mosquitos apresentou produção detectável e significativa desse isótipo $(p<$ 0,05 versus "PBS" - Figura 13C). Esses resultados mostram que a exposição repetida de camundongos BALB/c aos mosquitos induz a produção de anticorpos tanto do perfil Th1 (IgG2a) quanto Th2 (IgE e IgG1), sugerindo assim em um perfil misto de resposta, com tendência à polarização para um perfil Th2. Por outro lado, pode-se observar que ao contrário do que foi observado para os animais expostos aos mosquitos, a sensibilização com OVA induz a produção preferencial de isótipos IgE e IgG1, típicos de uma resposta Th2 clássica. 
Figura 13 - Determinação da concentração de anticorpos IgE total e IgG1 e IgG2a específicos no soro de animais sensibilizados com picadas do mosquito Ae. aegypti ou com OVA.

A

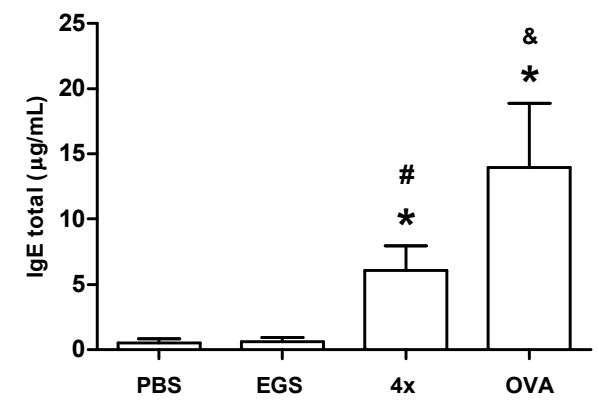

B

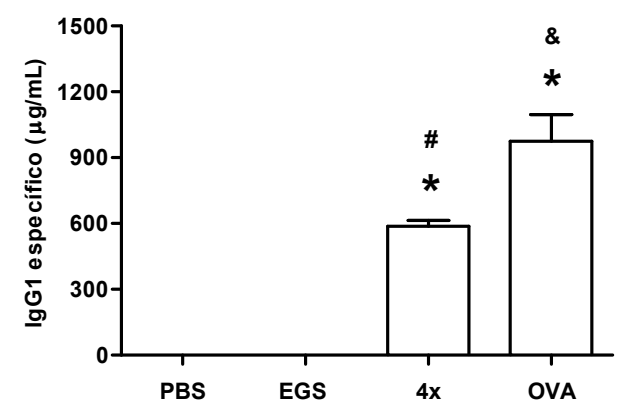

C

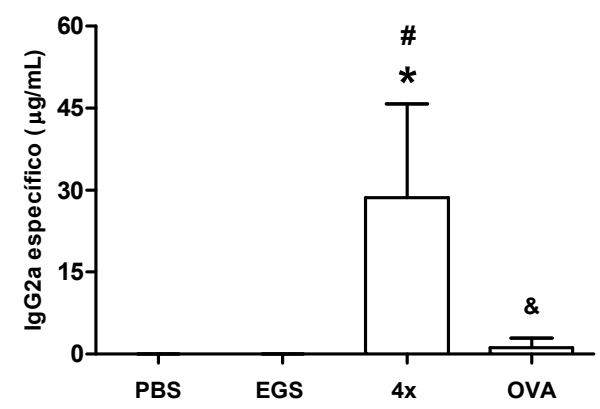

Um grupo de camundongos $\mathrm{BALB} / \mathrm{c}$ foi sensibilizado pela picada de mosquitos Ae. aegypti nos dias 0 , 14, 28 e 42 (grupo " $4 \mathrm{x}$ ") e desafiados com EGS i.n. nos dias 49 e 56. Outro grupo foi sensibilizado com OVA/Alum s.c. nos dias 0 e 7 e desafiados i.n. nos dias 14 e 28. Animais controle não sensibilizados foram apenas desafiados com PBS ou EGS i.n. 24 h após o segundo desafio, uma alíquota de sangue foi retirada para dosagem de anticorpos IgE (A), IgG1 (B) e IgG2a (C). A concentração dos anticorpos foi determinada por ELISA, conforme descrito em Material e Métodos. Resultados expressos como média \pm SEM $(\mathrm{n}=8) .{ }^{*} p<0,05$ versus grupo "PBS", ${ }^{p} p<0,05$ versus grupo "EGS", ${ }^{\&} p<0,05$ versus grupo " $4 \mathrm{x}$ ". 


\subsubsection{Mecânica pulmonar}

Nosso próximo passo foi avaliar alterações da mecânica pulmonar dos animais. Um dia após o primeiro desafio com PBS, EGS ou OVA, camundongos sensibilizados ou não foram colocados em câmaras pletismográficas onde foram mantidos acordados e receberam inalação de PBS e de metacolina. Animais sensibilizados pelas picadas dos mosquitos e desafiados com EGS não apresentaram alteração no padrão respiratório em resposta à metacolina. A Figura 14A mostra que os valores de Penh do grupo "4x" não apresentaram diferença significativa em relação aos grupos "PBS" e "EGS". Por outro lado, os animais sensibilizados e desafiados com OVA apresentaram alteração no padrão respiratório de maneira dose dependente após estímulo com metacolina e essa diferença foi significativa quando comparada ao grupo "PBS" $(p<0,05)$.

Para confirmar se a ausência de alterações no padrão respiratório se correlaciona com alterações na reatividade das vias aéreas, foi realizado um ensaio de reatividade in vitro com traqueia isolada. Para isso, animais sensibilizados ou não pela picada de mosquitos Ae. aegypti e desafiados com EGS ou PBS tiveram a traqueia removida para determinação da resposta contrátil após estimulação com metacolina. Podemos notar que não foram observadas alterações na reatividade da traqueia à metacolina de animais sensibilizados quando comparada com a resposta obtida no grupo controle (Figura 14B). Para descartar possíveis alterações decorrentes do desafio com EGS, a reatividade da traqueia de animais sensibilizados ou não que receberam apenas PBS i.n. foi avaliada. Também nesse caso não observamos diferença na resposta contrátil da traqueia em resposta a estímulo colinérgico entre camundongos sensibilizados $(4 \mathrm{x} / \mathrm{PBS})$ e controle (PBS/PBS) (Figura 14C). 
Figura 14 - A sensibilização com picadas do mosquito Ae. aegypti não altera o padrão respiratório nem a reatividade das vias aéreas de camundongos BALB/c.

A

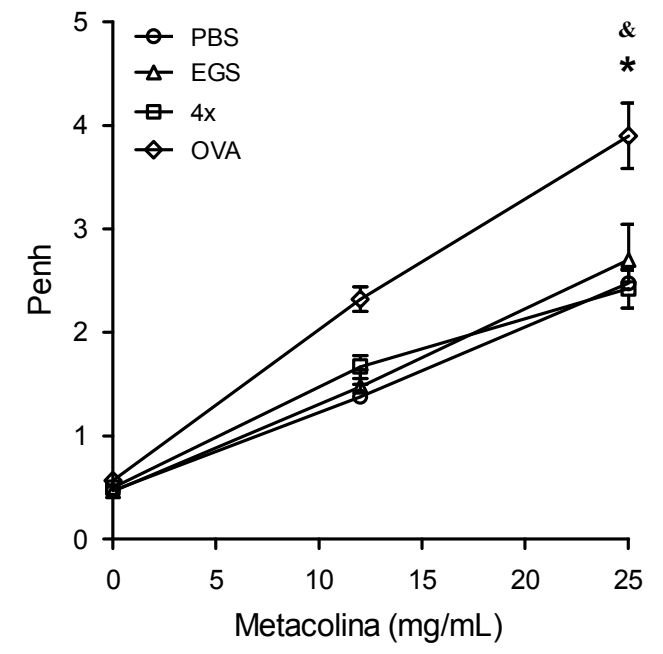

B

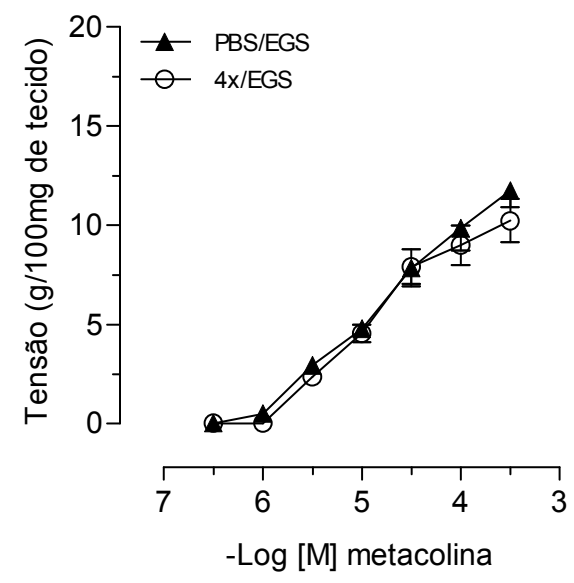

C

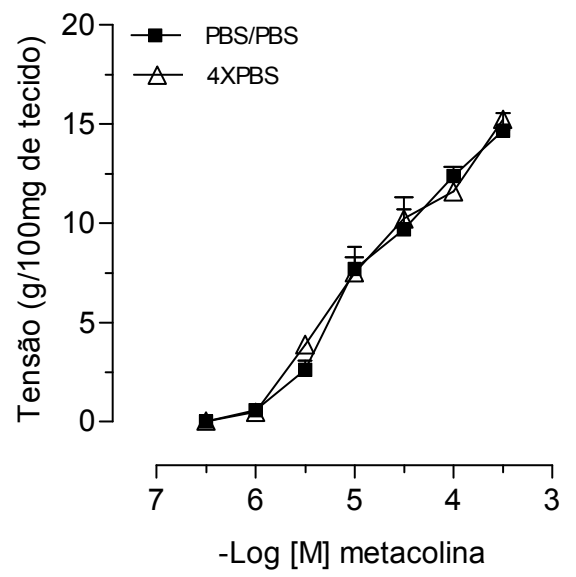

Camundongos BALB/c foram sensibilizados pela picada de mosquitos Ae. aegypti nos dias 0, 14, 28 e 42 (grupo "4x") e desafiados com EGS i.n. nos dias 49 e 56. Outro grupo foi sensibilizado com OVA/Alum s.c. nos dias 0 e 7 e desafiados i.n. nos dias 14 e 28. Animais controle não sensibilizados foram apenas desafiados com PBS ou EGS i.n. Após $24 \mathrm{~h}$ do primeiro desafio, o padrão respiratório em resposta a metacolina pela média dos valores de Pehn (A) foi analisado e a reatividade da traqueia in vitro foi investigada utilizando curva concentração-efeito a metacolina $\left(10^{-9}\right.$ a $\left.10^{-3} \mathrm{M}\right) 24 \mathrm{~h}$ após o segundo desafio (B e C). Resultados expressos como média \pm SEM $(\mathrm{n}=5-8) .{ }^{*} p<0,05$ versus grupo "PBS", ${ }^{\#} p<0,05$ versus grupo "EGS", \& $p<0,05$ versus grupo " $4 \mathrm{x}$ ". 


\subsubsection{Histopatologia pulmonar}

Finalmente, realizamos a análise histopatológica dos pulmões de animais dos diversos grupos experimentais para avaliação da inflamação e da produção de muco e colágeno nos pulmões, como descrito em Material e Métodos.

As imagens de cortes histopatológicos apresentados na Figura 15 mostram que, em relação aos animais controle, os animais sensibilizados e analisados $24 \mathrm{~h}$ após o segundo desafio apresentaram infiltrado celular na região peribroncoalveolar, sugerindo que houve migração de células para o parênquima pulmonar e subsequentemente para o espaço broncoalveolar. Tanto os animais expostos aos mosquitos quanto os que foram sensibilizados com OVA apresentaram um aumento no infiltrado inflamatório na região peribroncovascular (Figuras 15C e D, respectivamente) em comparação ao grupo "PBS" (Figuras 15A e B, respectivamente).

Além disso, produção aumentada de muco pelas células do epitélio brônquico dos animais do grupo "4x" (Figura 16C) e "OVA" (Figura 16D) também foi observada, quando comparados ao grupo "PBS" (Figuras 16A e B, respectivamente). Além disso, o grupo “OVA" também se mostrou diferente em relação ao grupo " $4 \mathrm{x}$ ” $(p<0,05)$. Estas observações foram confirmadas através de análise morfométrica, cujos resultados estão apresentados na Figura 16E.

A Figura 17 mostra que a quantificação de colágeno foi bastante semelhante nos pulmões de animais sensibilizados pelos mosquitos ou com OVA e desafiados com EGS (Figura 17 C) ou OVA i.n. (Figura 17 D), respectivamente. Ambos os grupos sensibilizados apresentaram uma aumento significativo na deposição de colágeno quando comparados ao grupo "PBS" (Figuras 17A e B, respectivamente). A Figura 17E mostra os resultados da análise morfométrica para quantificação do colágeno. 
Figura 15 - Infiltrado inflamatório no parênquima pulmonar de animais controles (PBS), animais desafiados com componentes salivares de Ae. aegypti (EGS) e de animais expostos às picadas de Ae. aegypti e desafiados com EGS (4x) ou sensibilizados e desafiados com OVA.
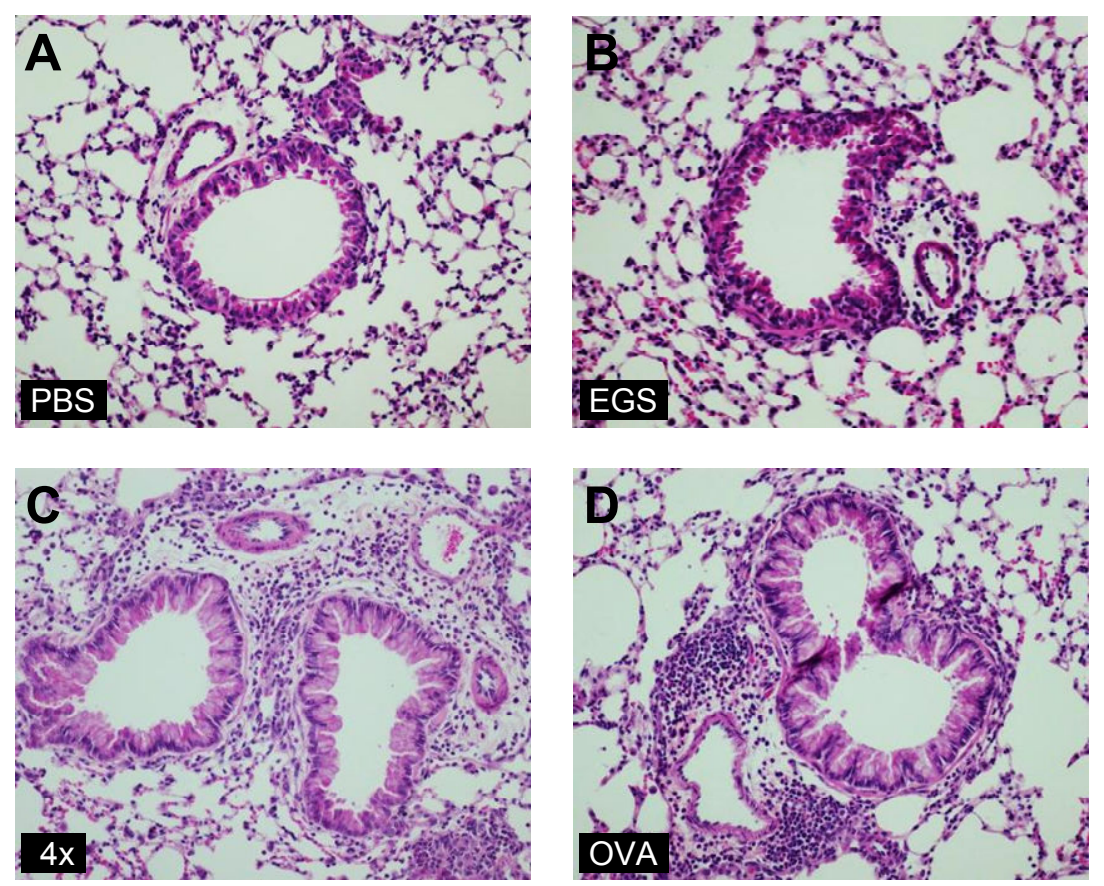

Após a coleta do LBA, os pulmões foram perfundidos e coletados para análise histológica conforme descrito em Material e Métodos. Para analise do infiltrado celular as lâminas foram coradas com Hematoxilina/Eosina. Fotomicrografias representativas do tecido pulmonar (aumento de 200x) dos grupos: (A) PBS, (B) EGS, (C) “4x” e (D) OVA ( $n=8)$. 
Figura 16 - Produção de muco no parênquima pulmonar de animais controles (PBS), animais desafiados com componentes salivares de Ae. aegypti (EGS) e de animais expostos às picadas de Ae. aegypti e desafiados com EGS (4x) ou sensibilizados e desafiados com OVA.
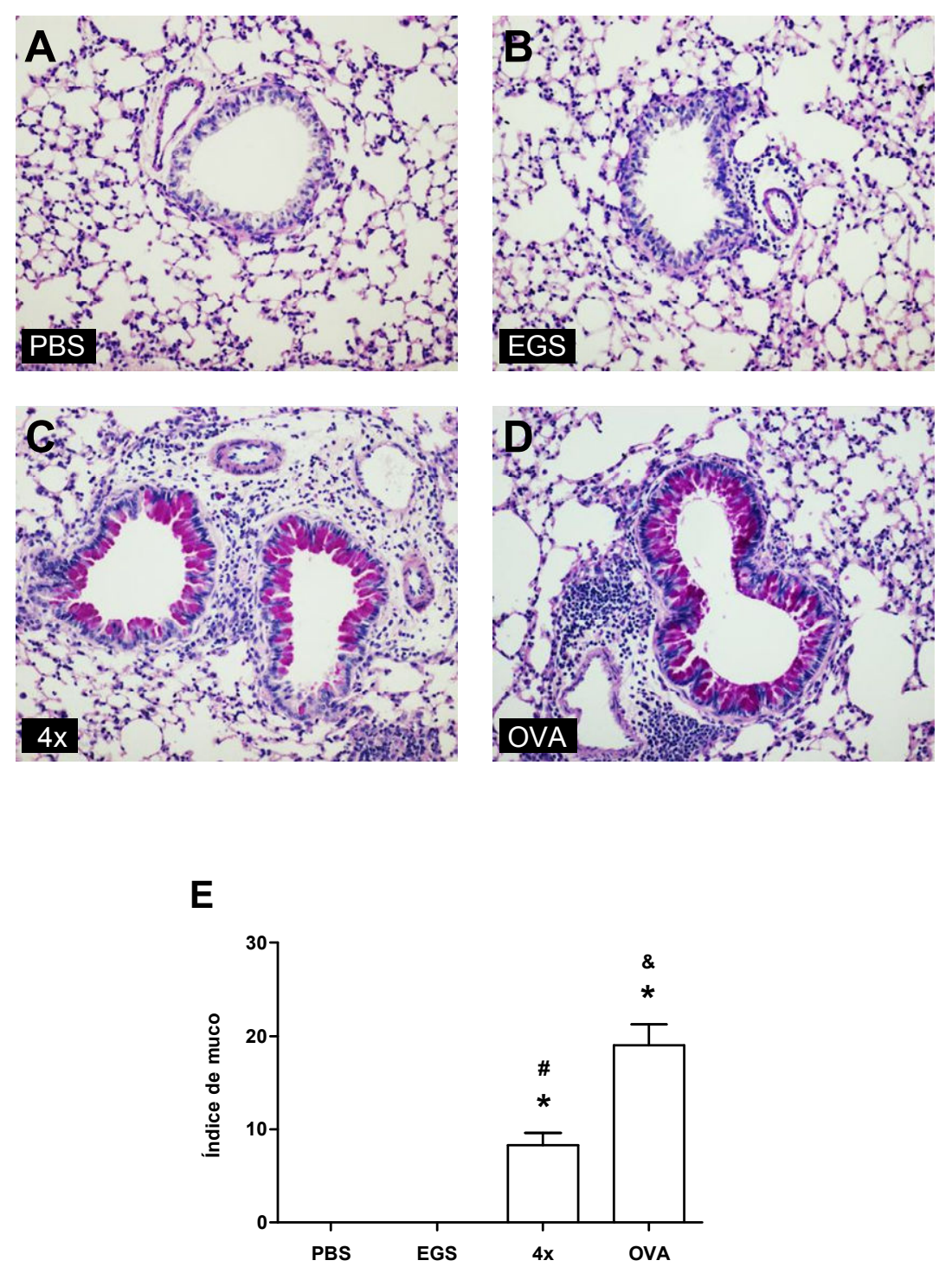

Após a coleta do LBA, os pulmões foram perfundidos e coletados para análise histológica conforme descrito em Material e Métodos. Para análise da produção de muco as lâminas foram coradas com PAS. A análise morfométrica da produção de muco está representada na Figura E. Fotomicrografias representativas do tecido pulmonar (aumento de 200x) dos grupos: (A) PBS, (B) EGS, (C) " $4 \mathrm{x}$ " e (D) OVA. Resultados expressos como média \pm SEM $(\mathrm{n}=8) .{ }^{*} p<0,05$ versus grupo "PBS", ${ }^{\#} p<0,05$ versus grupo "EGS", ${ }^{\circ}<0,05$ versus grupo " $4 \mathrm{x}$ ". 
Figura 17 - Deposição de colágeno no parênquima pulmonar de animais controles (PBS), animais desafiados com componentes salivares de Ae. aegypti (EGS) e de animais expostos às picadas de Ae. aegypti e desafiados com EGS (4x) ou sensibilizados e desafiados com OVA.
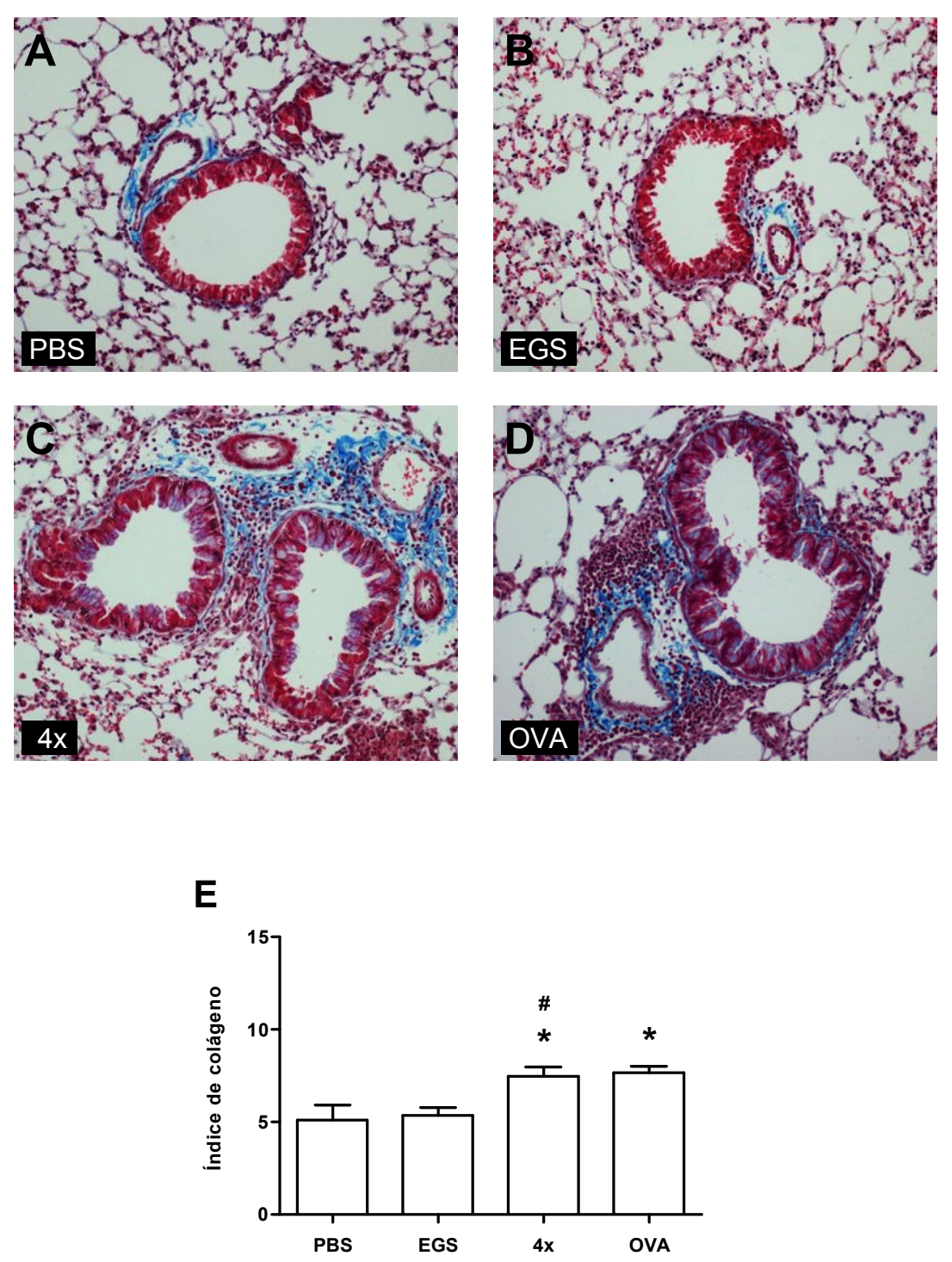

Após a coleta do LBA, os pulmões foram perfundidos e coletados para análise histológica conforme descrito em Material e Métodos. Para análise da produção da deposição de colágeno ao redor dos brônquios, as lâminas foram coradas com PAS. A análise morfométrica da deposição de colágeno está representada na Figura E. Fotomicrografias representativas do tecido pulmonar (aumento de 200x) dos grupos: (A) PBS, (B) EGS, (C) “4x" e (D) OVA. Resultados expressos como média \pm SEM (n=8). *p $<0,05$ versus grupo "PBS", $p<0,05$ versus grupo "EGS", ${ }^{\&} p<0,05$ versus grupo "4x". 


\subsection{Avaliação do repasto sanguíneo em camundongos expostos aos mosquitos $A e$. aegypti}

Como explicado na introdução, acredita-se que a imunidade do hospedeiro vertebrado pode afetar o comportamento alimentar dos mosquitos. Por essa razão, em nosso último experimento avaliamos esse parâmetro, uma vez que os mosquitos estavam disponíveis após cada um dos repastos sanguíneos. Entretanto, não foram observadas alterações qualitativas no comportamento alimentar dos mosquitos, sendo que em praticamente todos os casos, pelo menos $90 \%$ dos mosquitos realizaram seu repasto sanguíneo normalmente. Porém, como mostra a Figura 18, vimos que uma quantidade maior de sangue foi ingerida por mosquitos que se alimentaram em camundongos que já haviam sido previamente expostos aos mosquitos e esse aumento foi proporcional ao número de exposições. Esse padrão foi consistente e estatisticamente significativo em todos os experimentos realizados, sendo 1 a $34 \%$ maior na segunda exposição, 27 a 73\% maior na terceira exposição e 17 a $80 \%$ maior na quarta exposição, sempre em relação ao primeiro repasto. 
Figura 18 - Repasto sanguíneo de mosquitos Ae. aegypti fêmeas em camundongos sensibilizados.
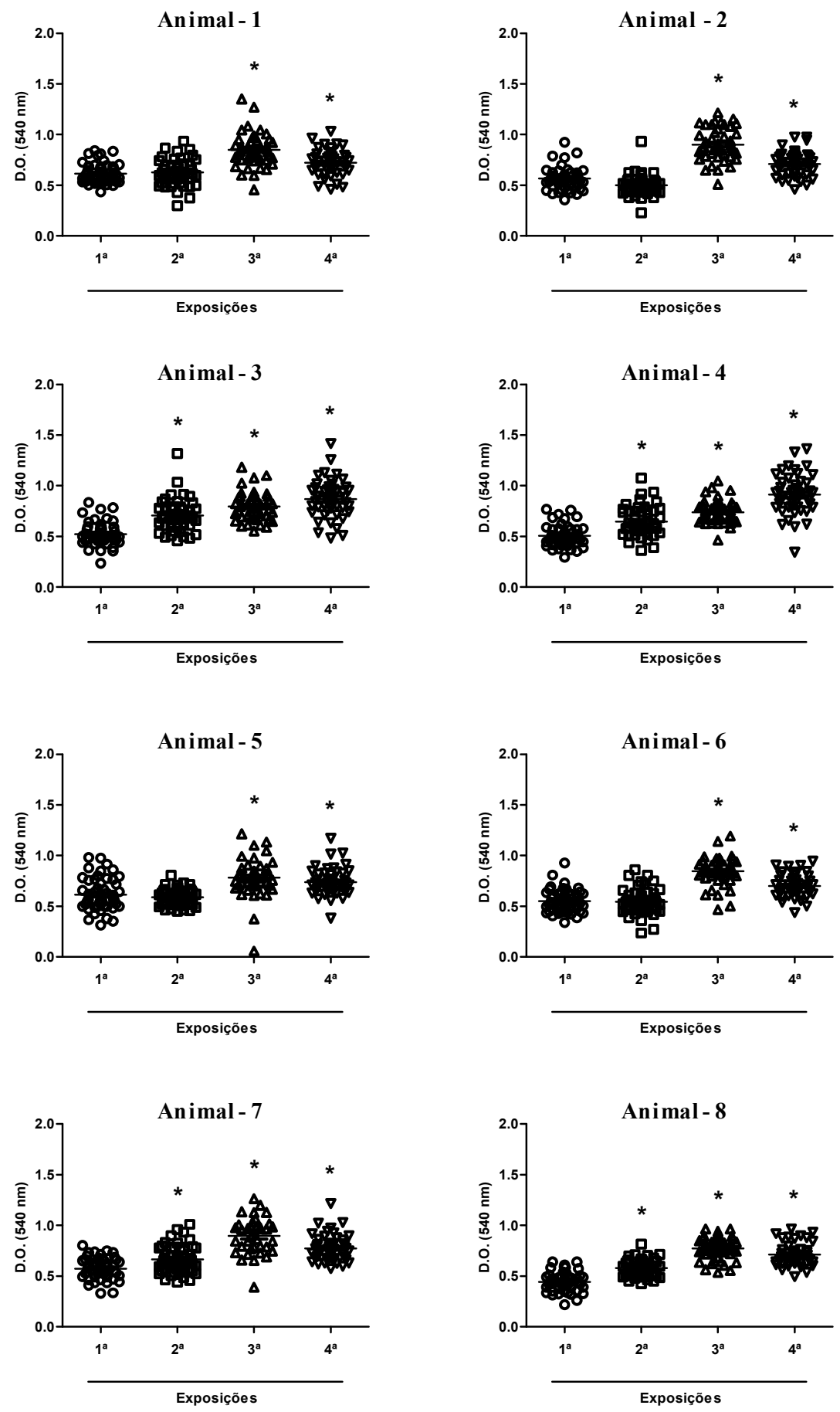

Cada mosquito coletado após as sensibilizações foi macerado em um tubo contendo água destilada e o homogeneizado foi centrifugado. O sobrenadante foi utilizado para quantificação da hemoglobina, como descrito em Material e Métodos. Resultado representativo de um experimento com $\mathrm{n}=8$, expressos pela Media \pm SEM. * $p<0,05$ versus grupo "1 a exposição". 
5 DISCUSSÃO 
Em 1906, Clemens von Pirquet cunhou o termo "alergia" para chamar a atenção para a propensão atípica de alguns indivíduos a desenvolver sinais e sintomas de reatividade, ou "reações de hipersensibilidade", quando expostos a certas substâncias (GALLI et al., 2008). Sensibilizações alérgicas são comumente induzidas por antígenos ambientais como ácaros, pólen e proteínas animais, podendo desencadear doenças como, por exemplo, asma alérgica, rinite alérgica, dermatite atópica e algumas alergias a comidas. Algumas pessoas desenvolvem uma reação alérgica sistêmica potencialmente fatal, denominada anafilaxia, em segundos ou minutos após a exposição à alérgenos (SAMPSON et al., 2005). A World Allergy Organization White Book on Allergy 2011-2012 estima que cerca de 30-40\% da população mundial seja afetada por uma ou mais condições alérgicas (EAST, 2011). Nas últimas três décadas tem sido observado um aumento significativo na prevalência de doenças alérgicas, porém, em países em desenvolvimento há uma prevalência consideravelmente mais baixa dessas doenças (YAZDANBAKHSH et al., 2002; WHO, 2007). Para a maioria das pessoas, a exposição diária a alérgenos produz pouco, ou nenhum, sintoma clínico. No entanto, em alguns indivíduos a exposição a um alérgeno pode quebrar o estado natural de tolerância e desencadear uma inflamação alérgica e uma resposta imune alérgeno-específica que é mantida por linfócitos T e B (JANEWAY; MEDZHITOV, 2002).

Neste estudo apresentamos dados iniciais acerca da resposta local e sistêmica causada pela exposição a componentes salivares do mosquito Ae. aegypti. Para isso, padronizamos um modelo de inflamação pulmonar alérgica em camundongos expostos a picadas de Ae. aegypti, comparando-o com o modelo bem estabelecido de alergia induzida por OVA. Assim, avaliamos a resposta imunológica local (pulmão) e sistêmica (soro) aos componentes presentes na saliva desses mosquitos, realizando a quantificação total e diferencial de células presentes no LBA, a análise histológica do pulmão, a dosagem dos níveis de citocinas no LBA e de anticorpos séricos desses animais e análise do padrão respiratório e da reatividade da traqueia.

Nossos resultados mostram que o desafio intranasal com EGS em animais previamente sensibilizados com as picadas de Ae. aegypti, desencadeia uma inflamação pulmonar que é proporcional ao número de exposições às quais os grupos foram submetidos. O infiltrado inflamatório observado é constituído principalmente pelo influxo de células mononucleares e eosinófilos, embora também tenha sido verificado um pequeno, porém significativo, aumento de neutrófilos (Figura 5). Enquanto a contagem diferencial das células do LBA evidenciou aumento de eosinófilos nos grupos " $1 \mathrm{x}$ " e " $4 \mathrm{x}$ " e de neutrófilos somente no grupo " $4 \mathrm{x}$ ", a análise por citometria de fluxo mostrou que os eosinófilos estavam significativamente aumentados apenas no grupo " $4 \mathrm{x}$ ” e não foram observadas alterações no número de 
neutrófilos no LBA de camundongos sensibilizados (Figura 6). Acreditamos que essas diferenças ocorreram por conta da estratégia de análise utilizada na citometria de fluxo. Como essas células recém-migradas estão provavelmente ativadas, elas podem não se localizar exatamente na região esperada do dot plot onde foram delimitadas pelo gating. De qualquer forma, o perfil geral desse infiltrado é bastante semelhante, com presença significativa de eosinófilos nas duas metodologias utilizadas. Os eosinófilos também estiveram presentes em grande quantidade no tecido pulmonar, como observado nas avaliações por citometria de fluxo (Figura 10) e por histopatologia (Figura 15).

A fenotipagem da população linfocitária por citometria de fluxo também demonstrou a presença aumentada de células $\mathrm{CD}^{+}$(linfócitos T helper) e células $\mathrm{CD} 19^{+}$(linfócitos $\mathrm{B}$ ) no LBA (Figura 6). Porém, ao contrário dos eosinófilos que foram detectados em maiores números tanto no LBA quanto no parênquima pulmonar, os números de linfócitos $\mathrm{T}$ e $\mathrm{B}$ só se mostraram aumentados no LBA dos animais sensibilizados e desafiados com EGS, mas não no tecido pulmonar (Figura 7). Esse fato sugere que essas células tenham sido removidas durante a lavagem do espaço broncoalveolar ou mais provavelmente, que já tivessem migrado para esse microambiente em resposta ao desafio antigênico. Como o aumento de eosinófilos e de linfócitos não foi observado no grupo controle desafiado com EGS (grupo "EGS"), descartamos a existência de algum fator quimiotático intrínseco para estas células dentre os componentes presentes no EGS de Ae. aegypti. Vale ainda ressaltar que a resposta inflamatória observada nos grupos sensibilizados foi muito mais intensa no grupo " $4 \mathrm{x}$ ", sendo que o infiltrado inflamatório presente no LBA e pulmões dos animais desse grupo foi cerca de três vezes maior em relação ao grupo " $1 \mathrm{x}$ ". Por esse motivo, o grupo " $4 \mathrm{x}$ " foi selecionado para a comparação dos demais parâmetros com um modelo clássico de inflamação alérgica pulmonar induzida pela sensibilização e posterior desafio com OVA.

Os grupos " $4 \mathrm{x}$ " e "OVA" apresentaram aumento no número de células totais no LBA, com a presença de eosinófilos, células mononucleares e de um pequeno, porém significativo, número de neutrófilos (Figura 8). Uma posterior análise por citometria de fluxo apresentou resultados semelhantes a estes no que diz respeito aos eosinófilos, no entanto, com a utilização dessa técnica não foi possível novamente observar alteração no número de neutrófilos. Além disso, células $\mathrm{CD}^{+}$e $\mathrm{CD} 19^{+}$também estavam aumentadas no BAL dos grupos " $4 \mathrm{x}$ ” e OVA (Figura 9). No pulmão, porém, houve aumento somente no número de eosinófilos, não sendo possível observar diferença no número de neutrófilos, células $\mathrm{CD}^{+}$e $\mathrm{CD} 19^{+}$entre os diferentes grupos (Figura 10), como já observado nos experimentos anteriores. 
Embora ambos os protocolos tenham apresentado um perfil de migração semelhante para os diferentes tipos celulares, a resposta inflamatória do grupo "OVA" apresentou sempre uma maior amplitude em relação ao grupo exposto quatro vezes aos mosquitos (grupo "4x"). Tal fato pode ser explicado pelo uso de adjuvante durante a fase de sensibilização no grupo "OVA". De fato, os protocolos mais frequentemente utilizados para estudo das reações alérgicas em modelo murino envolvem a sensibilização pela injeção de antígenos em conjunto com o adjuvante hidróxido de alumínio (alum) para promover o desenvolvimento de uma resposta imunológica do tipo Th2 (BREWER et al., 1999). No entanto, a necessidade real do uso do adjuvante hidróxido de alumínio juntamente com OVA nos protocolos de indução de asma tem sido discutida nos últimos anos por este ser um método artificial quando comparado à fisiopatologia da doença em humanos. Além disso, foi demonstrado que é possível utilizar OVA na ausência de adjuvante para induzir alergia e que a resposta inflamatória alérgica observada é similar ao protocolo padrão com adjuvante, utilizado na maioria dos estudos (CONRAD et al., 2009).

Durante a fase de sensibilização dos grupos expostos ao Ae. aegypti, foi utilizado um protocolo de exposição natural às picadas desses mosquitos. Esta escolha permitiu que fosse avaliada a resposta imune induzida somente pelos componentes presentes na saliva dos mosquitos, uma vez que não houve adição de adjuvante durante o procedimento. Por outro lado, a sensibilização do grupo "OVA" foi realizada com uma quantidade conhecida dessa proteína adsorvida em hidróxido de alumínio. Por conta dessas diferenças, não é possível fazer uma comparação direta entre a potência dos dois protocolos na indução de resposta alérgica. Sabidamente, há uma série de componentes na saliva desses mosquitos capazes de elicitar alergia, mas ao contrário do que aconteceu no grupo "OVA", não é possível quantificar individualmente o papel dos alérgenos salivares inoculados em cada etapa de sensibilização e tampouco dizer à quais componentes salivares os camundongos estão desenvolvendo sua resposta. De qualquer maneira, a inclusão do grupo "OVA" em alguns experimentos teve como objetivo estabelecer um parâmetro de discussão para os eventos observados após a sensibilização às picadas dos mosquitos.

O recrutamento celular é um evento importante na inflamação e os números e tipos celulares envolvidos nos estágios iniciais de um recrutamento inflamatório influenciam no desenvolvimento da imunidade adquirida e consequentemente, em futuras respostas imunes (TEIXEIRA et al., 2005). Sabe-se que a formação de um microambiente inflamatório, que pode ser observado durante processos alérgicos, permite uma intensa migração de células para o tecido ou órgão afetado. Nesse sentido, as citocinas são componentes importantes e 
participam de várias etapas no desenvolvimento, manutenção e na exacerbação de respostas alérgicas. É bem documentado que respostas Th2 alérgeno-específicas com a subsequente liberação de citocinas são responsáveis pela cascata de eventos necessária para o desenvolvimento de uma resposta alérgica (WILLIAMS et al., 2012). Assim, avaliamos a participação das citocinas IL-4, IL-5, IL-10, IL-13, IL-17 e IFN- $\gamma$ na inflamação alérgica induzida pela exposição aos mosquitos e observamos que o processo alérgico desencadeado por ambos os protocolos experimentais induziu o aumento de células T CD4 $4^{+}$produtoras de IL-4 e IL-5 no pulmão de camundongos dos grupos " $4 \mathrm{x}$ " e "OVA". Entretanto, se por um lado não houve diferença no número de células $\mathrm{T} \mathrm{CD}^{+} \mathrm{IL}^{-} 5^{+}$entre os dois grupos, por outro, o grupo "OVA" apresentou uma quantidade superior de células T CD4 $4^{+} \mathrm{IL}-4^{+}$quando comparado ao grupo " $4 \mathrm{x}$ ” (Figuras 11A e 11B, respectivamente). Ao contrário, não foi observado aumento no número de células T CD4 $4^{+}$produtoras de IL-17 ou IFN- $\gamma$ (Figuras $11 \mathrm{C}$ e $11 \mathrm{D}$, respectivamente). A determinação das citocinas presentes no LBA refletiu o perfil observado por citometria de fluxo, sendo observado aumento de IL-4 e IL-5 nos grupos "4x" e "OVA", não sendo observadas diferenças nos níveis de IL-17. Além disso, foi vista uma diminuição nos níveis de IL-10 e IFN- $\gamma$ para os dois grupos experimentais (Figura 12).

A citocina IL-5 desempenha um papel importante na diferenciação, proliferação e ativação dos eosinófilos (FOSTER et al., 2001; ROGERIO et al., 2010 SANDERSON et al., 1992). Em circunstâncias normais, a migração de eosinófilos para os tecidos é regulada pela expressão constitutiva de eotaxina-1 (CCL11) (GOUON-EVANS et al., 2001; FOSTER et al., 2001; MISHRA et al., 1999). Em condições inflamatórias, porém, a IL-5 coopera com as eotaxinas 1, 2 e 3 (CCL11, CCL24 e CCL26) no recrutamento de eosinófilos (POPE et al., 2005; ZIMMERMANN et al., 2000). De fato, IL-5 é uma citocina essencial para a migração de eosinófilos da medula óssea para o sangue (FACCIOLI et al., 1996; ROGERIO et al., 2003) e é responsável pela diferenciação terminal e proliferação dos precursores eosinofílicos, assim como pela ativação de eosinófilos maduros (SANDERSON et al., 1985; YAMAGUCHI et al., 1988; CLUTTERBUCK et al., 1988; COEFFIER et al., 1991). Além disso, a IL-5 aumenta o número de células responsivas à eotaxina e prima os eosinófilos a responderem a ligantes de CCR3, o principal receptor das eotaxinas (HUMBLES et al., 2002; ZIMMERMANN et al., 2003). Adicionalmente, IL-4 e IL-13 são potentes indutores de eotaxinas e quando essas eotaxinas são administradas exogenamente, elas colaboram com a IL-5 na indução de IL-13 nos pulmões, sugerindo a existências de um feedback positivo entre essas citocinas e quimiocinas no recrutamento de eosinófilos (ZIMMERMANN et al., 2003). Apesar de não termos determinado a concentração de eotaxinas nem de mediadores lipídicos 
sabidamente envolvidos no recrutamento de eosinófilos, a presença maciça dessas células tanto no LBA quanto nos pulmões dos animais sensibilizados com picadas de Ae. aegypti associada com a presença de IL-4, IL-5 e IL-13, citocinas de perfil Th2, fortemente sugere que toda a alça de regulação descrita acima está presente em nosso modelo.

Muitos trabalhos têm sugerido a presença de células $\mathrm{T}$ durante a resposta a picadas de mosquito. A hipersensibilidade mediada por células $\mathrm{T}$ pode desempenhar um papel em reações tardias a picadas de mosquito. Já foi demonstrado que reações cutâneas tardias ocorrem após a transferência de células do baço, mas não de soro, de animais sensibilizados com componentes salivaresde Ae. aegypti e adjuvante de Freund em experimentos com cobaias (ALLEN, 1966). Além disso, a proliferação de linfócitos após estimulação com antígenos salivares foi significativamente maior em animais sensibilizados do que nos animais controle, sugerindo que os linfócitos estão envolvidos no desenvolvimento de reações imunológicas a saliva do mosquito (CHEN et al., 1998). Embora diferentes células efetoras contribuam para o desenvolvimento da doença alérgica, grande parte dos modelos experimentais apontam as células Th2 como sendo as principais, pois podem participar tanto direta quanto indiretamente desse evento por coordenar a atividade de outras células (FOSTER et al., 1996). A relação entre a presença de eosinófilos e o desenvolvimento de uma resposta imune pulmonar do tipo Th2 foi demostrada através do estudo utilizando camundongos deficientes para produção de eosinófilos. Nesse estudo, camundongos desprovidos de eosinófilos e que foram sensibilizados e desafiados com OVA apresentaram níveis reduzidos de citocinas IL-4, IL-5 e IL-13 quando comparados a camundongos selvagens submetidos ao mesmo tratamento. Além disso, nesse mesmo trabalho foi demonstrado que a ausência de eosinófilos também impede o recrutamento de células T para o pulmão (JACOBSEN et al., 2008). O aumento no número de eosinófilos no sangue e nos tecidos é marca de infecções por helmintos, alergia, asma, entre outras desordens (ROTHENBERG, 1998; STONE et al., 2010). As principais proteínas presentes nos grânulos dos eosinófilos são: a proteína básica principal (MBP - major basic protein), a proteína catiônica eosinofilica (ECP - eosinophil cationic protein), a peroxidase eosinofilica (EPO - eosinophil peroxidase), neurotoxina derivada de eosinófilos (EDN - eosinophil-derived neurotoxin). Quando ativados, os eosinófilos liberam o conteúdo desses grânulos e produzem espécies reativas de oxigênio (ROS - reactive oxygen species) causando danos no tecido pulmonar incluindo o aumento da resposta das vias aéreas a uma variedade de estímulos, o que pode ser refletido pela hiperreatividade das vias aéreas (AHR - do inglês "Airway hyperreactivity") à inalação de broncoconstritores como a metacolina. Em pacientes com asma, a MBP presente no soro e BAL se correlacionam com a hiperreatividade brônquica (STONE et al., 2010). Além 
disso, a presença de citocinas IL-4, IL-5 e IL-13 têm sido correlacionadas com a reatividade das vias aéreas (FOSTER et al., 2002; HERSHEY, 2003).

No pulmão não houve diferença na quantidade de células produtoras de IFN- $\gamma$ (Figura 11D), citocina característica de um perfil Th1, e os níveis dessa citocinas no LBA apresentou diminuição significativa nos grupos "4x" e "OVA" quando comparamos grupos controle e sensibilizados (Figura 12F). A diminuição dessa citocina também foi observada em outro estudo utilizando camundongos sensibilizados pelas picadas de Ae. aegypti, porém num compartimento diferente do pulmão. Em um modelo utilizando baixa infestação/exposição ao mosquito, quando as células do baço de camundongos sensibilizados foram estimuladas com saliva ou com alérgenos recombinantes de Ae. aegypti, a produção de IFN- $\gamma$ apresentou-se diminuída em relação às células dos camundongos controle não sensibilizados (CHEN et al., 1998).

As células T produtoras de IL-17 foram inicialmente descritas em modelos autoimunes e levou a caracterização desse novo subtipo de célula T auxiliar (MURPHY, 2003; LEE et al., 2010). A principal função das células Th17 parece ser a eliminação de patógenos para os quais as respostas Th1 ou Th2 não desempenham um papel protetor. No entanto, estas células são potentes indutoras de inflamação tecidual e têm sido associadas com a patogênese de muitas doenças autoimunes, resposta a patógenos extracelulares e doenças caracterizadas por uma inflamação neutrofílica crônica (KORN et al., 2009; LEE et al., 2010). Adicionalmente, os níveis de IL-17 estão aumentados no pulmão, escarro, lavado broncoalveolar e soro de pacientes com asma e a severidade da hiperresponsividade das vias aéreas (AHR) está positivamente relacionada com os seus níveis de expressão (MOLET et al., 2001). Na mesma linha, células T produtoras de IL-17a estão expandidas no sangue periférico de humanos alérgicos em comparação a doadores não alérgicos (MILOVANOVIC et al., 2010), enquanto a falta de IL-17a em um modelo murino de alergia pulmonar resultou numa diminuição da resposta Th2 para a sensibilização ao antígeno e deficiência do receptor da IL-17a reduziu o recrutamento de neutrófilo e eosinófilos (WANG; WILLS-KARP, 2011). Como alguns trabalhos demonstraram que durante o processo inflamatório, uma das funções da IL-17 é induzir o recrutamento de neutrófilos (NOVAK; BIEBER, 2003, IWAKURA et al., 2008, WANG; WILLS-KARP, 2011) e, embora pequeno, o aumento de neutrófilos foi significativo no LBA de animais sensibilizados, quantificamos os níveis de IL-17 no sobrenadante do LBA para investigar se essa citocina estaria relacionada com a migração de neutrófilos para o espaço broncoalveolar. Contudo, observamos que os níveis de IL-17 não estavam diferentes no BAL de animais sensibilizados e que também não houve diferença no número de células T $\mathrm{CD} 4^{+}$produtoras de IL-17 no pulmão. 
Em relação à produção de anticorpos, vimos que camundongos expostos repetidamente a picadas de Ae. aegypti apresentam aumento nos níveis de IgE total e IgG1 específico em relação aos controles, da mesma maneira observada no grupo OVA. No entanto, os níveis de IgG2a estavam aumentados somente no grupo " $4 \mathrm{x}$ ”, enquanto mostraram-se ausentes no grupo "OVA" (Figura 13). Esses resultados sugerem que a saliva de Ae. aegypti é capaz de estimular as células B de maneira T-dependente, induzindo a secreção de anticorpos tanto de perfil Th1 quanto Th2. Apesar de não observarmos diferenças nos níveis de IFN- $\gamma$ detectados no LBA nem no número de células $\mathrm{CD}^{+}$produtoras dessa citocina no pulmão nas condições avaliadas, os níveis de IL-4 detectados no grupo " $4 \mathrm{x}$ ” foram sempre significativamente menores do que no grupo "OVA". É possível que o período avaliado não tenha sido o mais adequado para a detecção de IFN- $\gamma$. Se uma ou mais dessas hipóteses estiverem corretas, poderiam explicar a ausência de polarização total para um perfil Th2 de resposta. Nesse sentido, nossos dados contrastam com os estudos conduzidos por Chen et al. (1998) e Wang et al. (1999), mostrando que tanto camundongos sensibilizados pela picada de mosquitos quanto camundongos sensibilizados com alérgeno salivar recombinante de Ae. aegypti na ausência de adjuvante, apresentam aumento significativo de IgE e IgG1, mas não de IgG2a. No entanto, não é possível fazer uma comparação direta dos nossos resultados com os publicados nestes trabalhos, pois foram utilizados protocolos de sensibilização distintos. Enquanto, Chen et al. (1998) sensibilizaram cada camundongo expondoos a 16 mosquitos, 2 vezes por semana por 4 semanas, neste projeto sensibilizamos cada camundongo expondo-os 4 vezes a 50 mosquitos com intervalo de 15 dias entre cada exposição. Além disso, Chen et al. (1998) observaram uma queda nos níveis de IgG2a no soro de animais sensibilizados e, coincidentemente, observamos este mesmo fenômeno em animais sensibilizados apenas 2 vezes utilizando um protocolo de baixa infestação (20 mosquitos/camundongo - dados não mostrados). Esses resultados sugerem que uma exposição aguda e de baixa intensidade (20 mosquitos/2 vezes) poderia induzir preferencialmente anticorpos com perfil Th2, enquanto uma exposição crônica e intensa ao mosquito (50 mosquitos/4 vezes), como a utilizada no presente trabalho, é capaz de induzir produção de um padrão misto de anticorpos Th1/Th2. Isso talvez explique porque seres humanos apresentam uma reação de pápula no início da sensibilização ao mosquito, mas que posteriormente desaparece indicando um processo natural dessensibilização (MELLANBY, 1946). Estamos planejando experimentos com outras abordagens experimentais a respeito desse assunto para melhor responder a essa questão.

O papel de determinadas classes de anticorpos em reações alérgicas já está bem estabelecido. IgE e IgG1 são os únicos isótipos capazes de induzir anafilaxia cutânea ativa e 
passiva (BECKER et al., 1971; MOTA et al., 1968; MOTA et al., 1968), por meio da ligação com FceRI e FcyRIII, respectivamente, na superfície de mastócitos (DOMBROWICZ et al., 1993; HAZENBOS et al., 1996; MIYAJIMA et al., 1997). A participação de IgE nesses processos está bem estabelecida tanto em modelos experimentais quanto na clínica (KAY et al., 1985; METZGER et al., 1987), sendo a IL-4 o principal fator de diferenciação para células Th2 e, juntamente com a IL-13, induzem a troca de classe para IgE nas células B (DE VRIES, 1998; FOSTER et al., 2002). Já o papel da IgG1 depende de sua origem. Enquanto a IgG1 induzida por IL-4 possui atividade anafilática, a IgG1 dependente de IL-12 ou IFN- $\gamma$ não possui essa atividade (FAQUIM-MAURO et al., 1999). Utilizando soro de um indivíduo alérgico a picadas de mosquitos, REUNALA et al. (1994) mostraram a presença de anticorpos IgE específicos para saliva ou componentes da glândula salivar de mosquitos Ae. communis e Ae. aegypti. Estudos posteriores mostraram a presença de IgG específica nas reações a picadas de mosquitos, sendo que o aumento nos níveis desses anticorpos se correlacionavam com o desenvolvimento de reações cutâneas e também com os níveis de IgE. Em síntese, esses achados mostraram que IgG também está envolvida no desenvolvimento de alergia a mosquitos (PENG et al., 1996). No modelo aqui descrito, demonstramos aumento de IgG1 específica para componentes salivares, sugerindo a participação dessa classe de anticorpos na resposta a resposta imune a picadas de mosquito. Necessitamos, porém, confirmar ainda se essa IgG1 é anafilática ou não.

Para investigar se a padrão respiratório dos animais apresentava alguma alteração após a exposição aos mosquitos e desafio com EGS, adaptamos metodologia previamente descrita por Russo et al. (2001) e Rodríguez et al. (2003), na qual analisamos a resposta pulmonar a metacolina em animais sensibilizados pela picada dos mosquitos e desafiados i.n. com EGS de Ae. aegypti, avaliando o padrão respiratório desses animais. Além disso, apesar de não termos investigado em detalhes a biologia dos eosinófilos presentes no tecido pulmonar, a presença dessas células e de citocinas envolvidas com reatividade das vias aéreas, não encontramos em nosso modelo evidência de alterações no padrão respiratório de camundongos sensibilizados pelas picadas após provocação com metacolina. Já os animais sensibilizados com OVA/alum apresentaram alteração no padrão respiratório ao estímulo de metacolina de maneira dosedependente (Figura 14). Paralelamente, foi realizado um ensaio de reatividade in vitro com a traqueia de animais expostos aos mosquitos e desafiados com EGS para investigar se este resultado poderia ser correlacionado com alterações na reatividade das vias aéreas. No entanto, não foi possível observar alterações da resposta contrátil desse tecido frente à estimulação com metacolina. DRAZEN et al. (2004) discutem que há pelo menos dois mecanismos distintos que podem explicar o desenvolvimento de hiperreatividade, sendo que um deles depende de IL-4, 
IgE e mastócitos (CORRY et al., 1996) e o outro, de IL-5 e eosinófilos (FOSTER et al, 1996). Nestes trabalhos, os autores estudaram a alteração na responsividade das vias aéreas alterando as citocinas presentes neste microambiente em camundongos sensibilizados com OVA. No primeiro trabalho, Corry et al. (1996) mostraram que camundongos tratados com anticorpo antiIL-4 durante a fase de sensibilização, mas não durante o desafio, previne a responsividade das vias aéreas. Ao contrário, foi observada uma inibição da eosinofilia, mas não da responsividade das vias aéreas, em camundongos tratados com anticorpos anti-IL-5. Assim, os autores concluem que não é possível atribuir um papel direto para a IL-5 ou eosinófilos na mediação da hiperatividade aguda das vias aéreas. O segundo trabalho não discute o papel da IL-4, mas como observaram que as alterações na responsividade das vias aéreas foram acompanhadas por alterações na eosinofilia, eles concluem que a IL-5 e eosinófilos são mediadores centrais na patogênese da doença pulmonar. No entanto, apesar do desenvolvimento de uma inflamação alérgica com altos níveis de eosinófilos e produção das citocinas IL-4 e IL-5 em proporções maiores que as observadas nos animais controle, os animais expostos às picadas dos mosquitos não apresentaram alteração da reatividade das vias aéreas.

Além do infiltrado eosinofílico, a produção de muco também é considerada um marcador da severidade da inflamação pulmonar. Os cortes histopatológicos de pulmão mostram que tanto os grupos expostos aos mosquitos e desafiado com EGS quanto os grupos sensibilizados e desafiados com OVA apresentaram intenso infiltrado celular peribroncovascular e produção aumentada de muco (Figuras 15 e 16, respectivamente). Corroborando com este resultado, vimos anteriormente que houve um aumento na produção da citocina IL-13 em camundongos sensibilizados pela exposição aos mosquitos ou com OVA (Figura 12) e esta citocina está diretamente envolvida na produção de muco (GRÜNIG et al., 1998; HERSHEY, 2003). Em relação ao colágeno vimos que houve um aumento semelhante nos grupos " $4 \mathrm{x}$ " e "OVA" em relação ao grupo controle (Figura 17). Sendo assim, pode-se dizer que exposições repetidas ao mosquito e seguidas por desafio intranasal induz aumento da produção de colágeno, mas não de forma tão marcante quanto ao observado para a produção de muco. A inflamação persistente provocada por seguidas exposições a um alérgeno causa diversas alterações estruturais nas vias aéreas. Coletivamente essas alterações são chamadas de "remodelamento das vias aéreas". Quando esta resposta inflamatória se torna crônica há expansão do leito vascular e aumento da quantidade de colágeno no tecido prejudicado levando ao remodelamento das estruturas das vias aéreas. É possível observar a deposição de colágeno em modelo de asma agudo, porém, no remodelamento pulmonar em modelo animal de asma crônica, a deposição de colágeno 
observada ao redor dos bronquíolos nos pulmões é muito mais intensa que a deposição observada no modelo desenvolvido neste estudo (BUSSE et al., 1999; STUMM et al., 2011).

Como descrito anteriormente, a imunização do hospedeiro com componentes estruturais ou presentes na saliva dos mosquitos pode ter um efeito negativo no seu ciclo de vida (SUTHERLAND; EWEN, 1974). Sendo assim, uma pergunta que surgiu durante o desenvolvimento do presente modelo foi se as repetidas exposições ao mosquito, realizadas durante o protocolo de sensibilização poderiam afetar a qualidade/quantidade do respasto sanguíneo. Para nossa surpresa, além de não apresentarem alterações qualitativas no comportamento alimentar, a quantidade de sangue ingerida pelos mosquitos que se alimentaram em camundongos sensibilizados foi ainda maior do que naqueles expostos pela primeira vez aos mosquitos. Alguns estudos demonstraram que os anticorpos anti-mosquito ou contra componentes salivares produzidos em camundongos inoculados com extrato de mosquito ou expostos a picadas podem reagir com uma série de antígenos do mosquito e interferir na fecundidade ou na alimentação dos mesmos (RAMASAMY et al. 1988; SUTHERLAND; EWEN, 1974). No entanto, Hatfield (1988) demonstrou que apenas mosquitos que se alimentaram em camundongos imunizados e livres apresentaram redução no sucesso da alimentação, pois quando os mosquitos foram colocados para se alimentarem em camundongos imunizados e imobilizados pelo efeito de anestésico, não foi observada alteração no processo de alimentação ou fecundidade dos mesmos. Da mesma forma, Dubin et al. (1948) e Ramasamy et al. (1988) também não relataram diferenças na alimentação de mosquitos expostos a coelhos imunizados.

Os altos títulos de anticorpos mosquito-específico observado em hospedeiros imunizados pela picada de mosquitos, especialmente anticorpos específicos para componentes da glândula salivar, podem agir para aumentar as reações do hospedeiro no local da picada (HATFIELD, 1988). As reações a picadas podem aumentar a irritabilidade do hospedeiro, o que pode trazer sérias consequências para o sucesso alimentar dos mosquitos. Neste caso, a resposta do hospedeiro pode estar atuando por meio do desenvolvimento de respostas de hipersensibilidade, pois há evidências de que a sensibilização com antígenos dos mosquitos pode provocar fortes reações de hipersensibilidade no local da picada (DUBIN et al., 1948). No entanto, não foi possível observar um efeito prejudicial durante a alimentação dos mosquitos em camundongos previamente sensibilizados e tal fato pode ter ocorrido por conta das nossas condições experimentais. A utilização de anestésico durante o processo de sensibilização pode ter interferido na qualidade do repasto desses mosquitos, pois dessa forma não houve rejeição comportamental por parte dos animais (ex.: coceira no local da picada ou 
movimento). Não podemos descartar também o aumento de massa dos animais entre as exposições, que vem acompanhado do aumento do volume de sangue no organismo e possivelmente da disponibilidade nos vasos sanguíneos na região da pele. Além disso, experimentos realizados em nosso laboratório têm demonstrado que o período de 30 minutos de exposição aos camundongos é muito longo para se determinar diferenças no repasto sanguíneo, pois decorrido esse período, a maioria dos mosquitos pode ter se alimentado independentemente da eficácia do repasto. Por último, esses mosquitos não foram acompanhados após o repasto para avaliação do fitness biológico (sobrevivência, ovoposição, viabilidade da prole, etc.) e comprovação da qualidade da alimentação. 
6 CONCLUSÕES 
Os resultados apresentados no presente trabalho confirmam que o modelo desenvolvido por nós de sensibilização pela exposição aos mosquitos Ae. aegypti seguido por desafio com componentes salivares, induz resposta sistêmica em camundongos, caracterizada por inflamação pulmonar alérgica. Porém, este modelo nos parece diferente do modelo clássico nessa área, utilizando OVA adsorvida em Alum. Observamos uma clara presença de eosinófilos e células $\mathrm{CD}^{+}{ }^{+}$e CD19 ${ }^{+}$no LBA, com produção de IL-4, IL-5 e IL-13, presença de muco e anticorpos IgE e IgG1 no soro, sugerindo um padrão Th2 de resposta. Entretanto, também observamos a presença de níveis aumentados de IgG2a no soro dos animais expostos aos mosquitos, sugerindo um perfil misto de resposta. Apesar de diversos elementos responsáveis pela hiperreatividade das vias aéreas estarem presentes, não foram observadas alterações do padrão respiratório ou responsividade da traqueia. Além disso, vimos que nas nossas condições experimentais, a sensibilização dos camundongos não afetou o repasto sanguíneo dos mosquitos utilizados neste estudo. 
REFERÊNCIAS 


\section{REFERÊNCIAS $^{1}$}

ALVERS, W. C. L., GORAYEB, I. S., LOUREIRO, E. C. B.. Bactérias isoladas de culicídeos (Diptera: Nematocera) hematófagos em Belém, Pará, Brasil. Rev. Pan-Amaz. Saúde, v. 1, p. 131-141, 2010.

ALLEN, J. R. Passive transfer between experimental animals of hypersensitivity to Aedes aegypti bites. Exp. Parasitol., v. 19, n. 1, p. 132-7, Aug 1966.

ANDERSON, S. D. et al. Comparison of mannitol and methacholine to predict exerciseinduced bronchoconstriction and a clinical diagnosis of asthma. Respir. Res., v. 10, p. 4, 2009.

ANDRADE, B. B. et al. Haematophagous arthropod saliva and host defense system: a tale of tear and blood. An. Acad. Bras. Cienc., v. 77, n. 4, p. 665-93, Dec 2005.

BAQUEIRO, T. et al. Respiratory allergy to Blomia tropicalis: immune response in four syngeneic mouse strains and assessment of a low allergen-dose, short-term experimental model. Respir. Res., v. 11, p. 51, 2010.

BARROS, M. S. Padronização de modelo de inflamação alérgica pela exposição a picadas de mosquitos Aedes aegypti. 92 f. Dissertação (Mestrado em Imunologia) - Instituto de Ciências Biomédicas, Universidade de São Paulo, São Paulo, 2012.

BECKER, E. L. Nature and classification of immediate-type allergic reactions. Adv. Immunol., v. 13, p. 267-313, 1971.

BEERNTSEN, B. T. et al. Characterization of the Sialokinin I gene encoding the salivary vasodilator of the yellow fever mosquito, Aedes aegypti. Insect. Mol. Biol., v. 8, n. 4, p. 45967, Nov 1999.

BIZZARRO, B. Efeito da saliva de Aedes aegypti sobre a diferenciação, maturação e função de células dendríticas e na proliferação de linfócitos T. 99 f. Dissertação (Mestrado em Biologia da Relação Patógeno-Hospedeiro) - Instituto de Ciências Biomédicas, Universidade de São Paulo, São Paulo, 2012.

BISSONNETTE, E. Y.; ROSSIGNOL, P. A.; BEFUS, A. D. Extracts of mosquito salivary gland inhibit tumour necrosis factor alpha release from mast cells. Parasite Immunol., v. 15, n. 1, p. 27-33, Jan 1993.

BORTOLATTO, J. et al. Toll-like receptor 4 agonists adsorbed to aluminium hydroxide adjuvant attenuate ovalbumin-specific allergic airway disease: role of MyD88 adaptor molecule and interleukin-12/interferon-gamma axis. Clin. Exp. Allergy, v. 38, n. 10, p. 166879, Oct 2008.

\footnotetext{
${ }^{1}$ De acordo com: ASSOCIAÇÃO BRASILEIRA DE NORMAS TÉCNICAS. NBR 6023: informação e documentação: referências: elaboração. Rio de Janeiro, 2002.
} 
BREWER, J. M. et al. Aluminium hydroxide adjuvant initiates strong antigen-specific Th2 responses in the absence of IL-4- or IL-13-mediated signaling. J. Immunol., v. 163, n. 12, p. 6448-54, Dec 1999.

BUSSE, W. et al. Airway remodeling and repair. Am. J. Respir. Crit. Care. Med., v. 160, n. 3, p. 1035-42, Sep 1999.

CALVO, E. et al. Aegyptin, a novel mosquito salivary gland protein, specifically binds to collagen and prevents its interaction with platelet glycoprotein VI, integrin alpha2beta1, and von Willebrand factor. J. Biol. Chem., v. 282, n. 37, p. 26928-38, Sep 2007.

CHAMPAGNE, D. E.; RIBEIRO, J. M. Sialokinin I and II: vasodilatory tachykinins from the yellow fever mosquito Aedes aegypti. Proc. Natl. Acad. Sci. U. S. A., v. 91, n. 1, p. 138-42, Jan 1994.

CHAMPAGNE, D. E. et al. The salivary gland-specific apyrase of the mosquito Aedes aegypti is a member of the 5'-nucleotidase family. Proc. Natl. Acad. Sci. U. S. A., v. 92, n. 3, p. 694-8, Jan 1995.

CHEN, X. G.; MATHUR, G.; JAMES, A. A. Gene expression studies in mosquitoes. Adv. Genet., v. 64, p. 19-50, 2008.

CHEN, Y. L.; SIMONS, F. E.; PENG, Z. A mouse model of mosquito allergy for study of antigen-specific IgE and IgG subclass responses, lymphocyte proliferation, and IL-4 and IFNgamma production. Int. Arch. Allergy Immunol., v. 116, n. 4, p. 269-77, Aug 1998.

CLUTTERBUCK, E. J.; SANDERSON, C. J. Human eosinophil hematopoiesis studied in vitro by means of murine eosinophil differentiation factor (IL5): production of functionally active eosinophils from normal human bone marrow. Blood, v. 71, n. 3, p. 646-51, Mar 1988.

COËFFIER, E.; JOSEPH, D.; VARGAFTIG, B. B. Activation of guinea pig eosinophils by human recombinant IL-5. Selective priming to platelet-activating factor-acether and interference of its antagonists. J. Immunol., v. 147, n. 8, p. 2595-602, Oct 1991.

CONRAD, M. L. et al. Comparison of adjuvant and adjuvant-free murine experimental asthma models. Clin. Exp. Allergy., v. 39, n. 8, p. 1246-54, Aug 2009.

CORRY, D. B. et al. Interleukin 4, but not interleukin 5 or eosinophils, is required in a murine model of acute airway hyperreactivity. J. Exp. Med., v. 183, n. 1, p. 109-17, Jan 1996.

CROSS, M. L.; CUPP, E. W.; ENRIQUEZ, F. J. Differential modulation of murine cellular immune responses by salivary gland extract of Aedes aegypti. Am. J. Trop. Med. Hyg., v. 51, n. 5, p. 690-6, Nov 1994.

CURTIS, C. F.; GRAVES, P. M. Methods for replacement of malaria vector populations. J. Trop. Med. Hyg., v. 91, n. 2, p. 43-8, Apr 1988.

DE VRIES, J. E. The role of IL-13 and its receptor in allergy and inflammatory responses. J. Allergy Clin. Immunol., v. 102, n. 2, p. 165-9, Aug 1998. 
DOMBROWICZ, D. et al. Abolition of anaphylaxis by targeted disruption of the high affinity immunoglobulin E receptor alpha chain gene. Cell, v. 75, n. 5, p. 969-76, Dec 1993.

DRAZEN, J. M.; ARM, J. P.; AUSTEN, K. F. Sorting out the cytokines of asthma. J. Exp. Med., v. 183, n. 1, p. 1-5, Jan 1996.

DUBIN, I. N.; REESE, J. D.; SEAMANS, L. A. Attempt to produce protection against mosquitoes by active immunization. Fed. Proc., v. 7, n. 1 Pt 1, p. 303, Mar 1948.

EAST, R. Allergies. Nature, v. 479, 7374th ed., p. 479, 2011. Suplemento 1.

EPSTEIN, M. M. Do mouse models of allergic asthma mimic clinical disease? Int. Arch. Allergy Immunol., v. 133, n. 1, p. 84-100, Jan 2004.

FACCIOLI, L. H. et al. IL-5 drives eosinophils from bone marrow to blood and tissues in a guinea-pig model of visceral larva migrans syndrome. Mediators Inflamm., v. 5, n. 1, p. 24$31,1996$.

FAQUIM-MAURO, E. L. et al. Cutting edge: mouse IgG1 antibodies comprise two functionally distinct types that are differentially regulated by IL-4 and IL-12. J. Immunol., v. 163, n. 7, p. 3572-6, Oct 1999.

FAUSTINO, L. et al. Regulatory $\mathrm{T}$ cells accumulate in the lung allergic inflammation and efficiently suppress T-cell proliferation but not Th2 cytokine production. Clin. Dev. Immunol., v. 2012, p. 721817, 2012.

FOSTER, P. S. et al. Interleukin 5 deficiency abolishes eosinophilia, airways hyperreactivity, and lung damage in a mouse asthma model. J. Exp. Med., v. 183, n. 1, p. 195-201, Jan 1996.

. Interleukins-4, -5, and -13: emerging therapeutic targets in allergic disease. Pharmacol. Ther., v. 94, n. 3, p. 253-64, Jun 2002.

. Elemental signals regulating eosinophil accumulation in the lung. Immunol. Rev., v. 179, p. 173-81, Feb 2001.

GALE, A. J. Continuing education course \#2: current understanding of hemostasis. Toxicol. Pathol., v. 39, n. 1, p. 273-80, Jan 2011.

GALLI, S. J.; TSAI, M.; PILIPONSKY, A. M. The development of allergic inflammation. Nature, v. 454, n. 7203, p. 445-54, Jul 2008.

GILLESPIE, R. D.; MBOW, M. L.; TITUS, R. G. The immunomodulatory factors of bloodfeeding arthropod saliva. Parasite Immunol., v. 22, n. 7, p. 319-31, Jul 2000.

GOUON-EVANS, V.; POLLARD, J. W. Eotaxin is required for eosinophil homing into the stroma of the pubertal and cycling uterus. Endocrinology, v. 142, n. 10, p. 4515-21, Oct 2001.

GROSSMAN, G. L.; JAMES, A. A. The salivary glands of the vector mosquito, Aedes aegypti, express a novel member of the amylase gene family. Insect. Mol. Biol., v. 1, n. 4, p. 
223-32, 1993.

GRÜNIG, G. et al. Requirement for IL-13 independently of IL-4 in experimental asthma. Science, v. 282, n. 5397, p. 2261-3, Dec 1998.

HAMELMANN, E.; GELFAND, E. W. IL-5-induced airway eosinophilia--the key to asthma? Immunol Rev, v. 179, p. 182-91, Feb 2001.

HAMMAD, H. et al. Inflammatory dendritic cells--not basophils--are necessary and sufficient for induction of Th2 immunity to inhaled house dust mite allergen. J. Exp. Med., v. 207, n. 10, p. 2097-111, Sep 2010.

HATFIELD, P. R. Anti-mosquito antibodies and their effects on feeding, fecundity and mortality of Aedes aegypti. Med. Vet. Entomol., v. 2, n. 4, p. 331-8, Oct 1988.

HAZENBOS, W. L. et al. Impaired IgG-dependent anaphylaxis and Arthus reaction in Fc gamma RIII (CD16) deficient mice. Immunity, v. 5, n. 2, p. 181-8, Aug 1996.

HECHT, O. Uber die Sprosspilze der Oesophagusastolpungen und uber die Giftigverkung der Speicheidrusen von Stechmucken. Arch. Schiffs Trop. Hyg., v. 32, p. 561-75, 1928.

HERSHEY, G. K. IL-13 receptors and signaling pathways: an evolving web. J. Allergy Clin. Immunol., v. 111, n. 4, p. 677-90; quiz 691, Apr 2003.

HOLGATE, S. T.; POLOSA, R. Treatment strategies for allergy and asthma. Nat Rev Immunol, v. 8, n. 3, p. 218-30, Mar 2008.

HUDSON, A.; BOWMAN, L.; ORR, C. W. Effects of absence of saliva on blood feeding by mosquitoes. Science, v. 131, n. 3415, p. 1730-1, Jun 1960.

HUMBLES, A. A. et al. The murine CCR3 receptor regulates both the role of eosinophils and mast cells in allergen-induced airway inflammation and hyperresponsiveness. Proc. Natl. Acad. Sci. U. S. A., v. 99, n. 3, p. 1479-84, Feb 2002.

IWAKURA, Y. et al. The roles of IL-17A in inflammatory immune responses and host defense against pathogens. Immunol. Rev., v. 226, p. 57-79, Dec 2008.

JACOBSEN, E. A. et al. Allergic pulmonary inflammation in mice is dependent on eosinophil-induced recruitment of effector T cells. J. Exp. Med., v. 205, n. 3, p. 699-710, Mar 2008.

JAMES, A. A. et al. Isolation and characterization of the gene expressing the major salivary gland protein of the female mosquito, Aedes aegypti. Mol. Biochem. Parasitol., v. 44, n. 2, p. 245-53, Feb 1991.

JAMES, A. A.; BLACKMER, K.; RACIOPPI, J. V. A salivary gland-specific, maltase-like gene of the vector mosquito, Aedes aegypti. Gene, v. 75, n. 1, p. 73-83, Jan 1989.

JANEWAY, C. A.; MEDZHITOV, R. Innate immune recognition. Annu. Rev. Immunol., v. 
20, p. 197-216, 2002.

KAY, A. B. et al. Leucocyte activation initiated by IgE-dependent mechanisms in relation to helminthic parasitic disease and clinical models of asthma. Int. Arch. Allergy Appl. Immunol., v. 77, n. 1-2, p. 69-72, 1985.

KORN, T. et al. IL-17 and Th17 Cells. Annu Rev. Immunol., v. 27, p. 485-517, 2009.

LEE, F. E.; GEORAS, S. N.; BECK, L. A. IL-17: important for host defense, autoimmunity, and allergy? J. Invest. Dermatol., v. 130, n. 11, p. 2540-2, Nov 2010.

LINO DOS SANTOS FRANCO, A. et al. Pulmonary neutrophil recruitment and bronchial reactivity in formaldehyde-exposed rats are modulated by mast cells and differentially by neuropeptides and nitric oxide. Toxicol. Appl. Pharmacol., v. 214, n. 1, p. 35-42, Jul 2006.

MCKIEL, J. A. Sensitization to mosquito bites. Can. J. Zool., v. 37, p. 341-351, 1959.

MELLANBY, K. Man's reaction to mosquito bites. Nature, v. 158, n. 4016, p. 554, Oct 1946.

METZGER, W. J. et al. Local allergen challenge and bronchoalveolar lavage of allergic asthmatic lungs. Description of the model and local airway inflammation. Am. Rev. Respir. Dis., v. 135, n. 2, p. 433-40, Feb 1987.

MILOVANOVIC, M. et al. Interleukin-17A promotes IgE production in human B cells. J. Invest. Dermatol., v. 130, n. 11, p. 2621-8, Nov 2010.

MISHRA, A. et al. Fundamental signals that regulate eosinophil homing to the gastrointestinal tract. J. Clin. Invest., v. 103, n. 12, p. 1719-27, Jun 1999.

MIYAJIMA, I. et al. Systemic anaphylaxis in the mouse can be mediated largely through IgG1 and Fc gammaRIII. Assessment of the cardiopulmonary changes, mast cell degranulation, and death associated with active or IgE- or IgG1-dependent passive anaphylaxis. J. Clin. Invest., v. 99, n. 5, p. 901-14, Mar 1997.

MOLET, S. et al. IL-17 is increased in asthmatic airways and induces human bronchial fibroblasts to produce cytokines. J. Allergy Clin. Immunol., v. 108, n. 3, p. 430-8, Sep 2001.

MOTA, I.; WONG, D.; SADUN, E. H. Mouse homocytotropic antibodies. I. Specific differentiation between mouse 7S gamma 1 and mouse reagin-like antibodies. Life Sci., v. 7, n. 24, p. 1289-93, Dec 1968.

MOTA, I. Properties of rat and mouse homocytotropic antibodies. In: K. F. Austen and E. L. Becker, eds. Biochemistry of the Acute Allergic Reactions. Blackwell Scientific Publications: Oxford and Edinburgh, 1968. 189 p.

MURPHY, C. A. et al. Divergent pro- and antiinflammatory roles for IL-23 and IL-12 in joint autoimmune inflammation. J. Exp. Med., v. 198, n. 12, p. 1951-7, Dec 2003.

NENE, V. et al. Genome sequence of Aedes aegypti, a major arbovirus vector. Science, v. 316, n. 5832, p. 1718-23, Jun 2007. 
NOVAK, N.; BIEBER, T. Allergic and nonallergic forms of atopic diseases. J. Allergy Clin. Immunol., v. 112, n. 2, p. 252-62, Aug 2003.

OHNMACHT, C.; VOEHRINGER, D. Basophils protect against reinfection with hookworms independently of mast cells and memory Th2 cells. J. Immunol., v. 184, n. 1, p. 344-50, Jan 2010 .

PENG, Z.; SIMONS, F. E. Mosquito allergy: immune mechanisms and recombinant salivary allergens. Int. Arch. Allergy Immunol., v. 133, n. 2, p. 198-209, Feb 2004.

. Advances in mosquito allergy. Curr. Opin. Allergy Clin. Immunol., v. 7, n. 4, p. 350-4, Aug 2007.

PENG, Z.; YANG, M.; SIMONS, F. E. Immunologic mechanisms in mosquito allergy: correlation of skin reactions with specific $\operatorname{IgE}$ and $\mathrm{IgG}$ antibodies and lymphocyte proliferation response to mosquito antigens. Ann. Allergy Asthma Immunol., v. 77, n. 3, p. 238-44, Sep 1996.

POPE, S. M. et al. Identification of a cooperative mechanism involving interleukin-13 and eotaxin-2 in experimental allergic lung inflammation. J. Biol. Chem., v. 280, n. 14, p. $13952-$ 61, Apr 2005.

RAMASAMY, M. S. et al. Anti-mosquito antibodies decrease the reproductive capacity of Aedes aegypti. Med. Vet. Entomol., v. 2, n. 1, p. 87-93, Jan 1988.

REUNALA, T. et al. Immunology and treatment of mosquito bites. Clin. Exp. Allergy, v. 20 Suppl 4, p. 19-24, Nov 1990.

Passive transfer of cutaneous mosquito-bite hypersensitivity by $\operatorname{IgE}$ anti-saliva antibodies. J. Allergy Clin. Immunol., v. 94, n. 5, p. 902-6, Nov 1994.

RIBEIRO, J. M. Role of saliva in blood-feeding by arthropods. Annu. Rev. Entomol., v. 32, p. $463-78,1987$.

Characterization of a vasodilator from the salivary glands of the yellow fever mosquito Aedes aegypti. J. Exp. Biol., v. 165, p. 61-71, Apr 1992.

Blood-feeding in mosquitoes: probing time and salivary gland anti-haemostatic activities in representatives of three genera (Aedes, Anopheles, Culex). Med. Vet. Entomol., v. 14, n. 2, p. 142-8, Jun 2000.

RIBEIRO, J. M. et al. Salivary apyrase of Aedes aegypti: characterization and secretory fate. Comp. Biochem. Physiol. B., v. 79, n. 1, p. 81-6, 1984.

An annotated catalogue of salivary gland transcripts in the adult female mosquito, Aedes aegypti. BMC Genomics, v. 8, p. 6, 2007.

RODRÍGUEZ, D. et al. Bacterial lipopolysaccharide signaling through Toll-like receptor 4 suppresses asthma-like responses via nitric oxide synthase 2 activity. J. Immunol., v. 171, n. 
2, p. 1001-8, Jul 2003.

ROGERIO, A. P. et al. Lafoensia pacari extract inhibits IL-5 production in toxocariasis. Parasite Immunol., v. 25, n. 7, p. 393-400, Jul 2003.

ROGERIO, A. P.; SÁ-NUNES, A.; FACCIOLI, L. H. The activity of medicinal plants and secondary metabolites on eosinophilic inflammation. Pharmacol. Res., v. 62, n. 4, p. 298307 , Oct 2010.

ROTHENBERG, M. E. Eosinophilia. N. Engl. J. Med., v. 338, n. 22, p. 1592-600, May 1998.

RUBIN, A. S. et al. Hiperresponsividade brônquica: diretrizes para testes de função pulmonar. J. Pneumol., v. 28, p. 101-21, 2002. Suplemento 3.

RUSSO, M. et al. Suppression of asthma-like responses in different mouse strains by oral tolerance. Am. J. Respir. Cell Mol. Biol., v. 24, n. 5, p. 518-26, May 2001.

SÁ-NUNES, A., OLIVEIRA, C. J. F. Sialogenins and other immunomodulators derived from blood feeding parasites. In: KINI, R. M., MCLANE, M. A., CLEMETSON, K. J., MARKLAND, F. S. JR., MORITA, T., eds. Toxins and Hemostasis: From Bench to Bedside. Springer, 2010. 22 p.

SAMPSON, H. A. et al. Symposium on the definition and management of anaphylaxis: summary report. J. Allergy Clin. Immunol., v. 115, n. 3, p. 584-91, Mar 2005.

SANDERSON, C. J. et al. The production of lymphokines by primary alloreactive T-cell clones: a co-ordinate analysis of 233 clones in seven lymphokine assays. Immunology, v. 56, n. 4, p. 575-84, Dec 1985.

SANDERSON, C. J. Interleukin-5, eosinophils, and disease. Blood, v. 79, n. 12, p. 3101-9, Jun 1992.

SCHNEIDER, B. S. et al. Aedes aegypti salivary gland extracts modulate anti-viral and TH1/TH2 cytokine responses to sindbis virus infection. Viral Immunol., v. 17, n. 4, p. 56573, 2004.

SIMONS, F. E.; PENG, Z. Skeeter syndrome. J Allergy Clin Immunol, v. 104, n. 3 Pt 1, p. 705-7, Sep 1999a.

. Mosquito allergy: recombinant mosquito salivary antigens for new diagnostic tests. Int Arch Allergy Immunol, v. 124, n. 1-3, p. 403-5, 2001 Jan-Mar 2001a.

SIMONS, F.; PENG, Z. Mosquito allergy. In: Levine M, Lockey R, editors. American Academy of Allergy, Asthma and Immunology monograph on insect allergy. 4th ed. Milwaukee, Wisconsin: American Academy of Allergy, Asthma and Immunology, 2003. p. 175-203.

STARK, K. R.; JAMES, A. A. A factor Xa-directed anticoagulant from the salivary glands of the yellow fever mosquito Aedes aegypti. Exp. Parasitol., v. 81, n. 3, p. 321-31, Nov 1995. 
. Isolation and characterization of the gene encoding a novel factor Xa-directed anticoagulant from the yellow fever mosquito, Aedes aegypti. J. Biol. Chem., v. 273, n. 33, p. 20802-9, Aug 1998.

STONE, K. D.; PRUSSIN, C.; METCALFE, D. D. IgE, mast cells, basophils, and eosinophils. J. Allergy Clin. Immunol., v. 125, n. 2 Suppl 2, p. S73-80, Feb 2010.

STUMM, C. L. et al. Airway remodeling in murine asthma correlates with a defect in PGE2 synthesis by lung fibroblasts. Am. J. Physiol. Lung Cell Mol. Physiol., v. 301, n. 5, p. L63644, Nov 2011.

SUTHERLAND, G. B.; EWEN, A. B. Fecundity decrease in mosquitoes ingesting blood from specifically sensitized mammals. J. Insect. Physiol., v. 20, n. 4, p. 655-60, Apr 1974.

TEIXEIRA, C. R. et al. Saliva from Lutzomyia longipalpis induces CC chemokine ligand 2/monocyte chemoattractant protein-1 expression and macrophage recruitment. J. Immunol., v. 175, n. 12, p. 8346-53, Dec 2005.

VALENZUELA, J. G. High-throughput approaches to study salivary proteins and genes from vectors of disease. Insect Biochem. Mol. Biol., v. 32, n. 10, p. 1199-209, Oct 2002.

VALENZUELA, J. G. et al. Toward a description of the sialome of the adult female mosquito Aedes aegypti. Insect Biochem. Mol. Biol., v. 32, n. 9, p. 1101-22, Sep 2002.

WANG, $\mathrm{H}$. et al. Induction of $\mathrm{IgE}$ responses using a recombinant mosquito salivary allergen rAed a 2 without adjuvant in mice. Int. Arch. Allergy Immunol., v. 120, n. 2, p. 135-40, Oct 1999.

WANG, Y. H.; WILLS-KARP, M. The potential role of interleukin-17 in severe asthma. Curr. Allergy Asthma Rep., v. 11, n. 5, p. 388-94, Oct 2011.

WASSERMAN, H. A.; SINGH, S.; CHAMPAGNE, D. E. Saliva of the Yellow Fever mosquito, Aedes aegypti, modulates murine lymphocyte function. Parasite Immunol., v. 26, n. 6-7, p. 295-306, 2004 Jun-Jul 2004.

WHO (World Health Organization). Asthma. vol. 307, mai. 2007. Disponível em: $<$ http://www.who.int/mediacentre/factsheets/fs307/en/index.html>. Acesso em: 12 Jan.2012.

WILLIAMS, C. M. et al. Cytokine pathways in allergic disease. Toxicol. Pathol., v. 40, n. 2, p. $205-15,2012$.

YAMAGUCHI, Y. et al. Purified interleukin 5 supports the terminal differentiation and proliferation of murine eosinophilic precursors. J. Exp. Med., v. 167, n. 1, p. 43-56, Jan 1988.

YAZDANBAKHSH, M.; KREMSNER, P. G.; VAN REE, R. Allergy, parasites, and the hygiene hypothesis. Science, v. 296, n. 5567, p. 490-4, Apr 2002.

ZEIDNER, N. S. et al. Mosquito feeding modulates Th1 and Th2 cytokines in flavivirus 
susceptible mice: an effect mimicked by injection of sialokinins, but not demonstrated in flavivirus resistant mice. Parasite Immunol., v. 21, n. 1, p. 35-44, Jan 1999.

ZIMMERMANN, N. et al. Chemokines in asthma: cooperative interaction between chemokines and IL-13. J. Allergy Clin. Immunol., v. 111, n. 2, p. 227-42; quiz 243, Feb 2003.

Murine eotaxin-2: a constitutive eosinophil chemokine induced by allergen challenge and IL-4 overexpression. J. Immunol., v. 165, n. 10, p. 5839-46, Nov 2000. 